Historic, archived document

Do not assume content reflects current scientific knowledge, policies, or practices. 

Established 1881

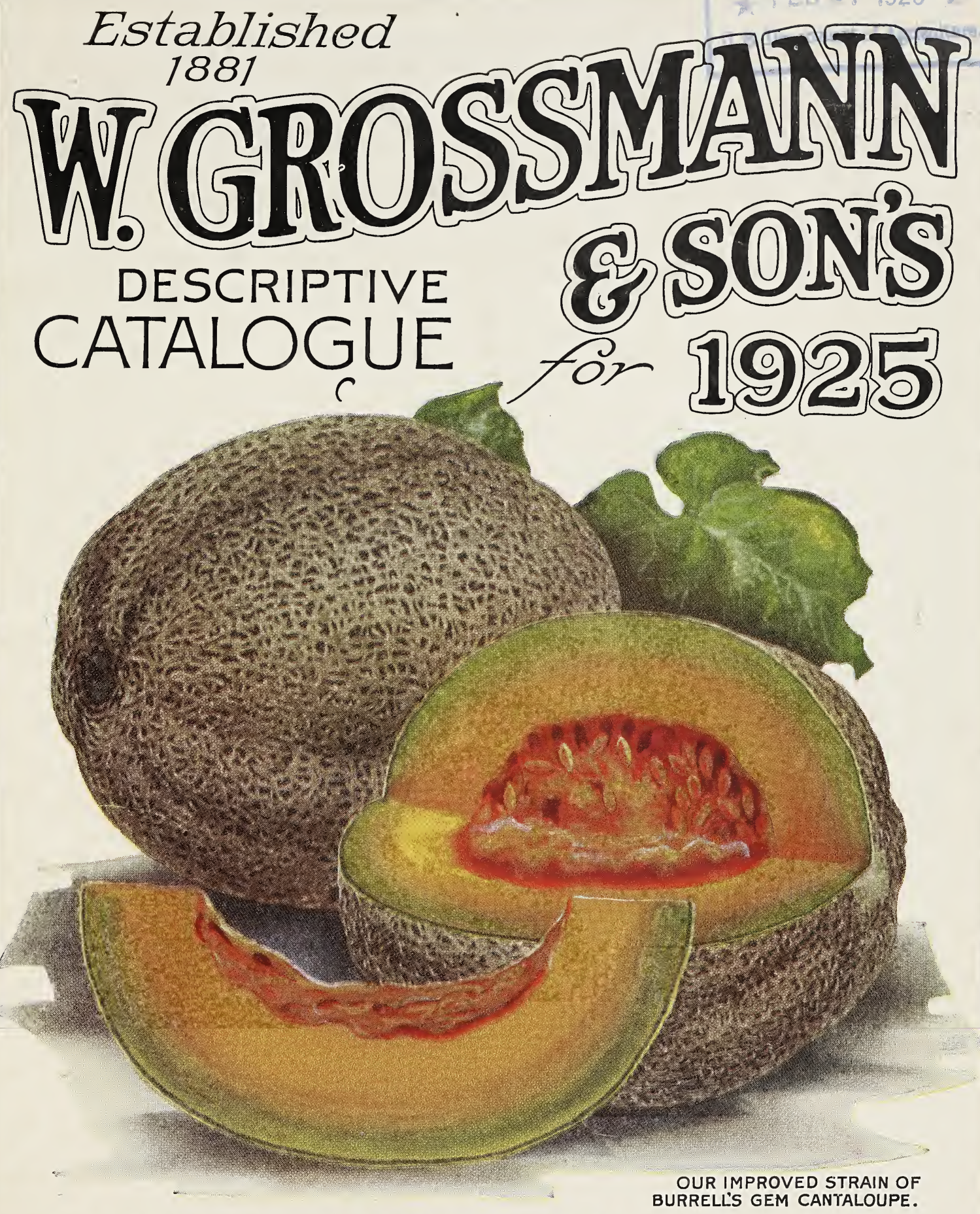

Field, Garden and Flower Seeds, Bulbs and Plants, Poultry Supplies and Foods, High Grade Fertilizers.

Wb GROSSMANN E SON 


\section{Bulbs for Spring Planting}

AII BUIBS QUOTED POSTAGE PREPAID.

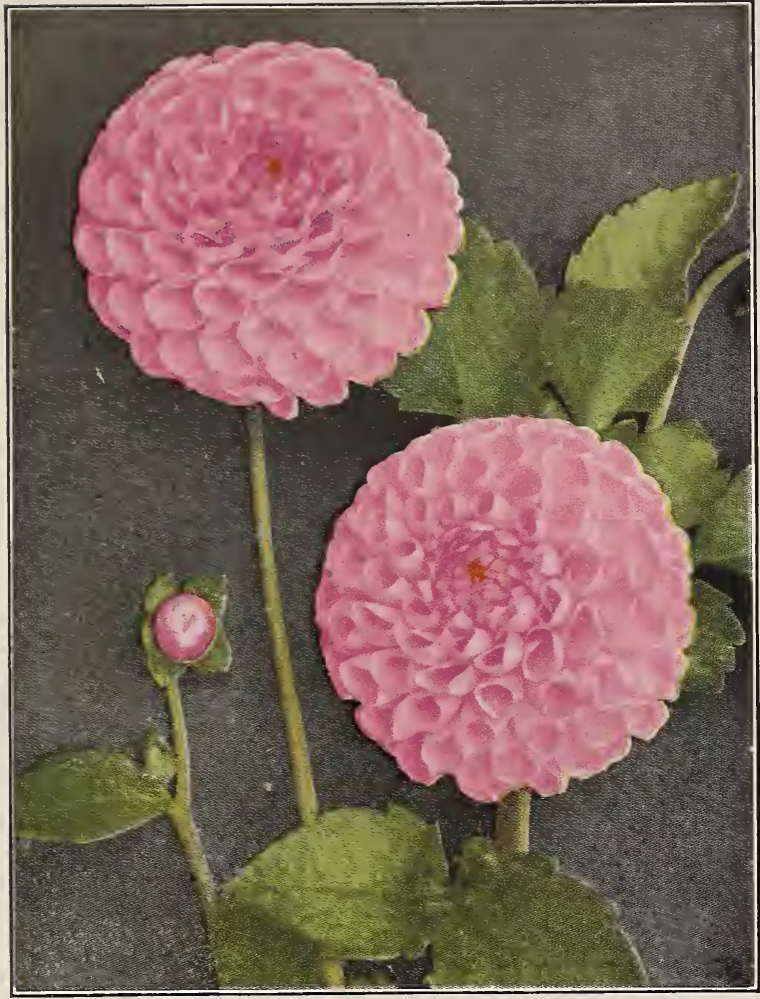

Show Dahlias.

CATADTUIMS, or ETEPHANT'S EAR-Very effective for beds or groups, especially in lawns. Grows from 6 to 8 feet high, bearing immense green leaves. Price, large sized, sound, healthy bulbs, 25c each; \$2.00 per dozen by express or parcel post prepaid.

FXCEISIOR PEARI TUBEROSES-Desirable for their beauty and delightful fragrance. Price per dozen, 35c; per 100, $\$ 2.50$ by parcel post prepaid.

\section{DAHLIAS}

\section{CIASSIFICATION OF DAFIIAS}

CACTUS-This class embraces the long, narrowpetaled varieties, the petals of which are generally pointed or twisted.

DECORATIVE-Large flowers, full centers, broad loose petals.

PEONY-Have large broad petals, open centers.

SHOW-The old-fashioned Dahlia, has large full head blooms.

Each variety quoted is of choice and proven quality, well worth a place in any garden.

Price, each 35c, postpaid.

PRINCE JUIIANA (Decorative)-Pure white. GOLDEN WEST (Decorative)-Primrose yellow. OREGON BEAUTY (Decorative)-Oriental red. JUIIFT (Cactus)-Light pink.

SIIMPIICITY (Cactus)-Pure lavender.

SNOWBAIL (Show)-Pure white.

DREER'S YEITOW (Show)-Pure yellow.

RED HUZZAR (Show)-Scarlet.

YEIIOW KING (Peony)-Yellow.

PENNANT (Peony)-Red.

\section{CANNAS}

Gorgeous and effective bedding plants-used for round beds or borders.

KING HUIMERT-4 ft. The grandest canna grown

The large, heart-shaped leaves are a beautiful

bronze. The plants are crowned with immense heads of orchid-like, velvety, orange-scarlet blooms. Price, $15 \mathrm{c}$ each; $\$ 1.00$ per doz.

IMRS. AIFRED CONARD-4 ft. The grandest salmon pink canna in existence. Magnificent heads of perfectly formed flowers of great size, beautiful green foliage. Price, 15c each; $\$ 1.00$ per doz.

RICHARD WAIIACE-4 ft. Canary yellow flowers. Profuse bloomer. Green foliage. Price, 10c each; 75c per doz.

EUREKA-4 ft. The best white canna for all purposes. Large, substantial flowers, produced freely on strong, vigorous plants, green foliage. Price, 15c each; $\$ 1.00$ per doz.

\section{GLADIOLUS}

\section{VERY SHOWY AND POPUIAR SUIMIMER FLOWERS-SELECTED BULBS}

AMrRICA-Soft lavender-pink. One of the finest for cutting. Price, 75c per doz.

AUGUSTA-One of the most popular white varieties for cutting. Price, 75 c per doz.

IIRS. FRANCIS KING-A striking shade of scarlet or flame color; very effective. Price, 60c per dozen.

HAEIFY-Salmon-pink, with red stripe. Price, 75c per dozen.

MIXED GIADIOIUS-A mixture of the best varieties. Price, 40c per dozen; \$2.75 per 100.

BARON HUIOT-Of rare dark violet color. Very attractive. Price, $\$ 1.00$ per dozen.

A liberal application of WIZARD BRAND FUIVERIZED SHFFP TMANURF will promote growth and enhance brilliancy of bloom.

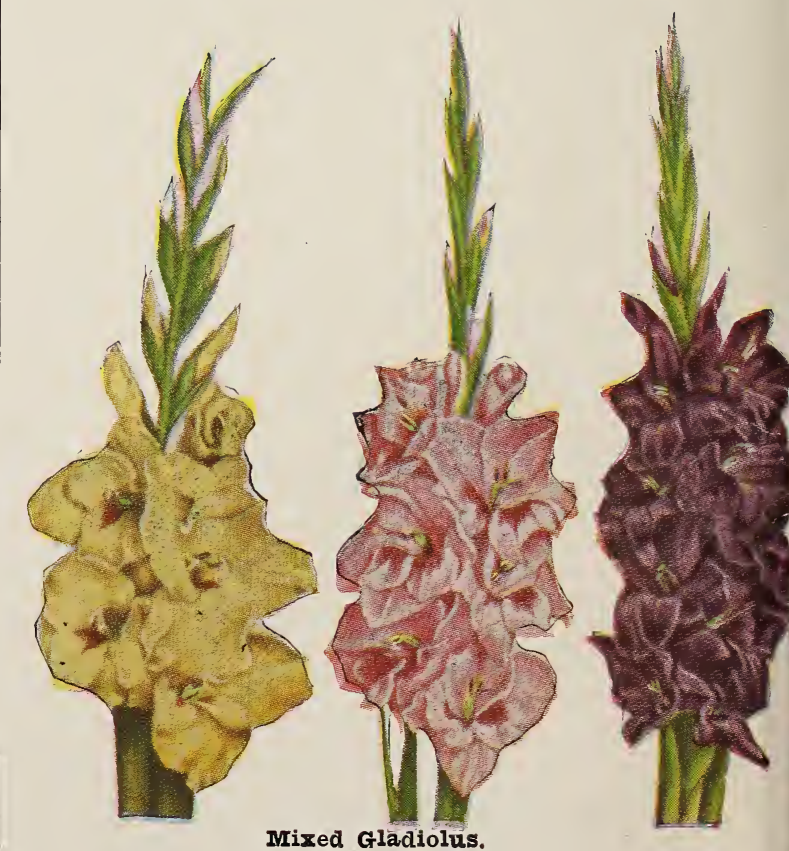




\section{$1925=\mathbb{T a}_{\mathfrak{d}}$ (D) $\mathbb{C}$ Ustomers=1925}

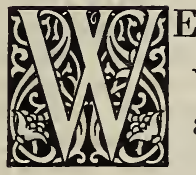

ARE again presenting our annual SEED CATALOG, and with it wish each and every one of our friends and customers a Happy and Prosperous New Year.

Due to unfavorable climatic conditions in general during the year 1924, a great many varieties of seeds are in short supply. This is particularly true in regard to seed corns of every description, and we strongly advise our friends to carefully preserve such stocks as they may have on hand, suitable for seeding purposes. Notwithstanding these shortages, we are ready to serve you with a fairly complete stock of our New Crop Seeds for Farm, Vegetable Gardens, and Flower Gardens-all grown by men who make a specialty of producing seeds "true to name."

Our prices will necessarily range slightly higher, but we give you the assurance that they are as low and reasonable as RELIABLE SEEDS can be grown and offered for sale under the conditions existing in the growing districts during 1924.

Secure in the knowledge that, through the vigilance and utmost care of our growers, and through our many years' experience, and our continued, untiring efforts, our Seeds are second to none in purity, germination, and productiveness, we again kindly solicit your valued business for this season. It shall be our pleasure to serve you during the year, and it shall be our aim to make each and every one of your transactions, your visits, or your inquiries to us one of mutual benefit. We thank you for your part in making our business a success, and with best wishes, we are,

Yours very truly,

\section{W. GROSSMANN \& SON}




\section{Insecticides}

\section{POISONS CANNOT BE SENT BY MAIL}

CARBOLA.-(Not for outside work.) A disinfecting, germ-killing, white paint recommended instead of whitewash and disinfectants. Ready to use by adding water. Makes light, sanitary, sweet-smelling interiors, and kills lice, mites, etc., and prevents spread of contagious diseases. Fine for hen houses, chicken coops, and other outbuildings. Trial pkg. $40 \mathrm{c}$ postpaid. $10=\mathrm{Ib}$. plkg. $\$ 1.25$ by express.

DICHLORICIDE.-Used for the extermination of Peach Tree Borer. Applied around the roots of the tree when dormant. Price, $1=1 b$. tin, $60 \mathrm{c}$; $5=1 b$. tin, $\$ 2.50$.

RED WING POWDER.-For the destruction of roaches, flies, bed bugs, moths, mosquitos, ants, flees-and other insects. Also destroys lice on rose bushes, chrysanthemums and other flowers-and plants. Price, 30c per pkg. post= paid; 25c per pkg. not prepaid.

RAT CORN.-A dry powder or meal to be mixed with any food that rats and mice will eat. It is an effective poison, and the dead rats have no odor, as they are mummified by eating this poison. A most effective and sanitary Rat Exterminator. Price, 25c and 50c packages.

PARIS GREEN.-Very effectual for destroying potato bugs and other insects. A very strong poison, and should be used carefully. Mix one pound Paris Green to 50 pounds of Plaster, or to 150 gallons of water. Price: $1 / 4=1 b$. pkg., 15c; I/2=lb. pkg., 25c; 1=lb. pkg., 50c.

POWDERED ARSENATE OF LEAD.-This is undoubtedly the best insecticide known. Recommended for spraying potatoes, vegetables, tobacco, etc. Does not burn foliage. Especially recommended to our tobacco growers. Can be used as a powder or in water. Easily handled and appliêd. $1 / 2=1 \mathrm{~b}$. pkg., 20c; 1=lb. pkg., 35c; 5-1b. pkg., \$1.50; 50=lb. pkg., \$12.50.

BORDEAUX MIXTURE.-This is a splendid Insecticide as well as a promoter of growth to plants. Especially recommended for spraying tomatoes and other delicate plants. Should be used by all truckers and gardeners. To be diluted 10 to 20 times with water, and used as a spray. Price: $1=1 \mathrm{lb} ., 40 \mathrm{c} ; 5$ lbs., $\$ 1.60$.

HAMMOND'S SLUG SHOT.-A very effective insecticide and very popular on account of not being injurious to human beings. Recommended for roses and other flowers. Price: 1=lb. pkg. 25c; 5=lb. pkg. 50c; 10=lb. pkg. \$1.00.

POTATO SPRAY. - A preparation of Paris Green and Bordeaux combined. Very effective for destroying potato bugs and other insects, at the same time being a preventative against blight. Apply like Paris Green. Price: 1=lb. pkg. 40c.

TOBACCO DUST. - Splendid for dusting of melons, squash and other vegetables. Destroys insects and acts as a fertilizer. Price: 3=ib. pkg. 25c; 8=lb. pkg. 50c postpaid.

DRY LIME AND SULPHUR SOLUTION.This material is identical with the lime and sulphur solution which we have been supplying our trade for spraying. It is in a dry state, and is much easier to handle, and very simple to use. Absolutely necessary for destroying San Jose Scale and other diseases of nursery stock. A one-pound can of Dry Lime and sulphur will make five gallons of spray, ready for use. Simply dump the powder in the spray tank, and add the water. Price: $1=1 b$. can, $30 \mathrm{c} ; 5=1 \mathbf{b}$. can, $\$ 1.25 ; \quad 10=16$. can, $\$ 2.00 ; 25=1 b$. can, $\$ 3.50$; $50=1 \mathrm{~b}$. can, $\$ 6.00$.

NIAGARA IAND DUST GUN; A PACKAGE OF NIAGARA ALL-IN=ONE MIXTURE; NIAGARA GARDEN GUIDE.-All packed together in a carton ready to go home and put into in. stant use. A quick, sure and convenient way to relieve yourself of all worries over destruction to vegetables, flowers, shrubbery, house plants, etc., caused by injurious pests and diseases. Kills all pests and diseases without the use of water. No mussy chemicals. Price, complete outfit, $\$ 3.50$ or $\$ 3.75$ postpaid.

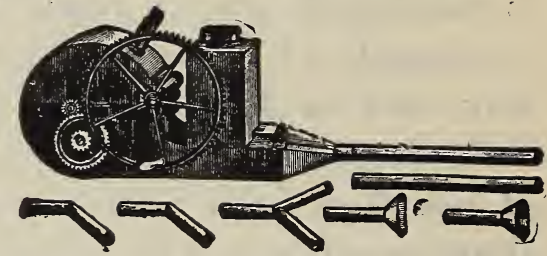

LITTLE GIANT DUSTER.-Distributes any dry powder, like Dry Arsenate of Lead, Slug Shot and Paris Green, to perfection. Keeps the poison at a safe distance from the operator, and will dust potato plants as fast as the operator can walk, two rows at a time. One of the best appliances for tobacco growers. By turning a handle a fan is rapidly revolved, distributing the insecticides uniformly on two rows at once, and to all parts of the plant and on both sides of the leaf. Price, $\$ 11.00$.

BLACK LEAF 40. - Nicotine Sulphate, $40 \%$ Nicotine. This is the insecticide that is so highly recommended by Experiment Stations. It destroys Aphis (plant lice), Thrips, Leaf-hoppers on all tree, bush and vine fruits, vegetables, field crops, flowers and shrubs; also Apple Red Bug, Pear Psylla and similar soft-bodied sucking insects-all without injury to foliage. May be combined with other sprays. Highly concentrated. Soluble in water-easy to mix-does not clog nozzles. Complete directions with each package. $1 \mathrm{oz}$......\$.35-makes 6 gallons of spray.

r $/ 2$ lb...... 1.25-makes 40 to 120 gals. spray 2 lbs...... 3.75-makes 160 to 500 gals. spray

STIMUPLANT.-A highly concentrated, odorless fertilizer for the vegetable and flower garden shrubs and house plants. The analysis is guaranteed 11 per cent nitrogen, 12 per cent phosphoric acid, 15 per cent potash, an ample amount of each plant food to insure a quick and strong growth of all plants, earlier maturity of garden vegetables, and a generous supply of blooms from flowering plants. 10 tablet pkg. 15c; 30 tablet pkg. 25c; 100 tablet pkg. $75 \mathrm{c}$.

SCALECIDE.- "A complete dormant spray." This is a complete liquid spray, which will kill all kinds of scale on fruit, shade and ornamental trees; easy and pleasant to handle and nse, and guaranteed to give results. Price: Qt. 50c; gal. \$1.50. 


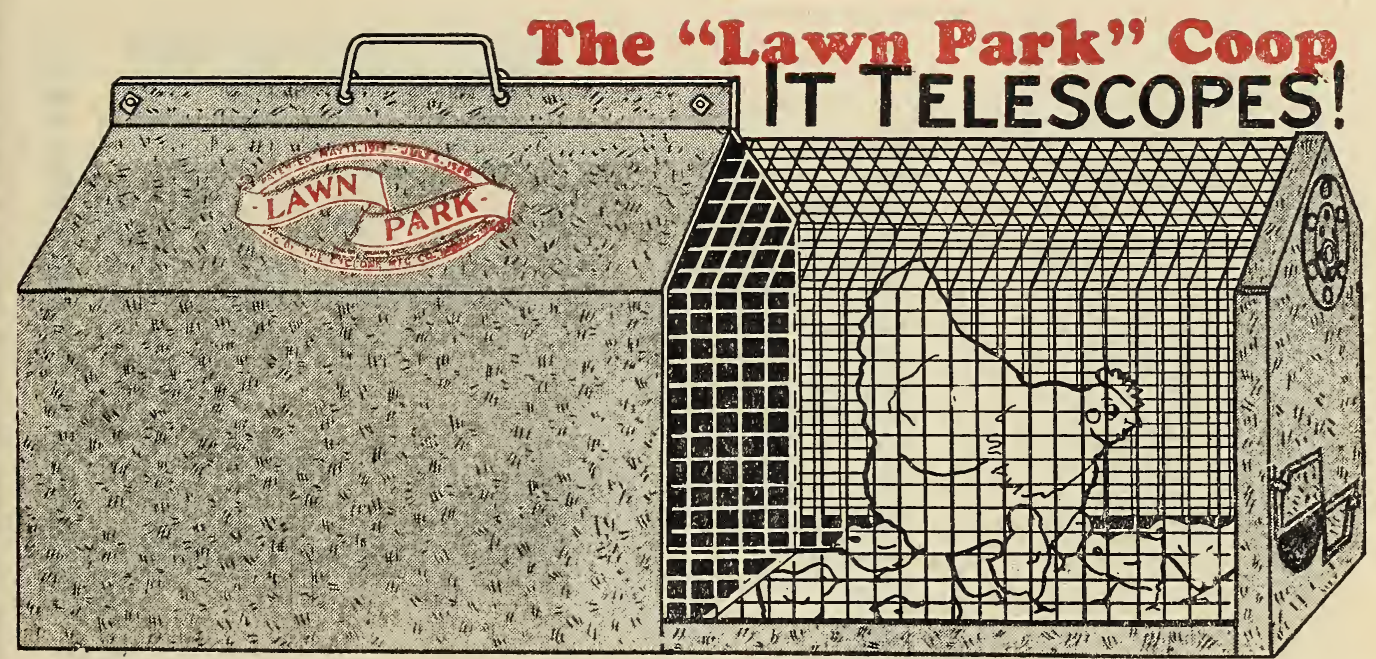

Send Orders to GUNN SEED CO., Lincoln Nebr. 


\section{Give Afle Chich a Chance \\ Trey are Money Makers}

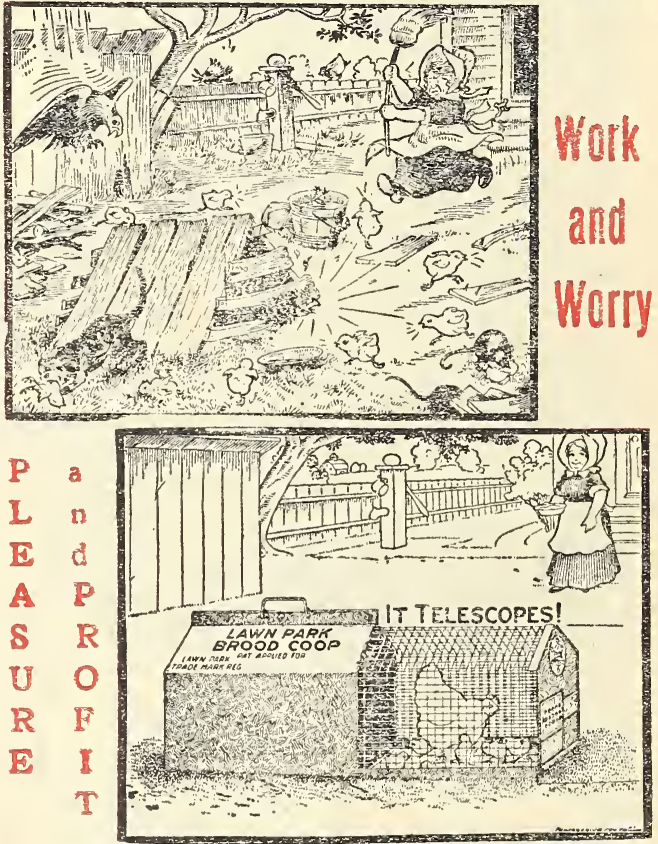

USE THE LAWN TARK COOP

The outstanding features of the Lawn Park is its sturdy and practical construction. The body is formed from one piece of heavy galvanized iron, without seam joint, rivet or solder. The bottom is elevated and without slip joints and can be removed or replaced in a "Jiffy." The front is provided with two Hinged doors, and damper ventilator, and is attached to $1 / 2$ inch mesh, galvanized hardware cloth, on runners, and pushed in and out like a bureau drawer.

Size of coop: Park extended, 18 inches wide, $191 / 2$ inches high, and 48 inches long. When park is closed, coop is 24 inches long. The most practical brood coop on the market. Hundreds of Thousands in use.

You make no mistake when you order LAWN PARK COOPS 


\section{Important Notes and Suggestions}

HOW TO SEND MONEY. Remittances should be made either in the form of an Express Money Order, P. O. Money Order, Bank Draft, or Registered Letter. Postage stamps will be accepted for small amounts, provided they are carefully wrapped so as to prevent sticking.

Be Sure to Give Full Name and Address with each order. Every season we get a number of orders without name of sender or Post Office, and the postmark on the envelope is often too obscure to be made out. There is no way of finding out who the senders are, consequently we are blamed, whereas the fault is their own entirely. We therefore beg our correspondents to write their name and full address on each order.

SEEDS BY EXPRESS. By special agreement, the Express Companies wili carry Seeds from Petersburg to all points at an average rate of about 20 per cent. less than the usual merchandise rate, and a package weighing 5 pounds or less will be delivered to any Express Office in the State of Virginia, for 25 cents when prepaid. Goods wanted C. O. D. by express must have 25 per cent. of the amount accompany the order.

ORDERS FROM UNKNOWN CORRESPONDENTS. Customers who have no regular accounts with us will kindly remit the amount with their order, or name business reference, as customary before opening new accounts.

We Make No Charge for Drayage or delivery of goods to any railroad station, steamship line or express office in Petersburg. Cotton sacks only are charged for at cost. $21 / 2$ bushel Cotton Sacks are 45 cents each. All grass seed bags, excepting bags for Timothy, Herds Grass and Clover, are furnished free.

CLAIMS. All claims for shortage, loss or damage to shipments, must be made promptly upon receipt of goods, otherwise we cannot allow such claims.

REMEMBER. Our packets of seed are large and well filled, and should not be confused with the $2 \frac{1}{2}$ cent and 3 cent size packets sold by some dealers.

CHANGE OF ADDRESS. Should any of our customers change their Post Office address, we would be glad if they would advise us. It also sometimes happens that our customers receive two Catalogues; should you receive two, we would thank you to hand one to some friend who does not get one, and notify us, so that we may make the correction in our directories.

PRICES ON FIELD SEEDS, UNION SETS AND POTATOES are constantiy fluctuating. The prices given in this Catalogue are those ruling January 1, 1925. But they may change at any time. We will cheerfully quote prices at any time on request, and we will always fill orders entrusted to us at the lowest prices possible for the best quality seeds.

ABOUT WARRANTING SEEDS. We exercise the greatest possible care in growing or buying, in examining, in testing, and in every department of the business to guard against mistakes and insure reliability, yet no Seedsman can, or ever does in good faith assume any responsibility for crops grown from seeds supplied by them, therefore in common with other responsible Seed Houses, we sell our goods subject to the following disclaimer, it being that adopted by the American Seed Trade Association, and all orders sent us will be filled under these conditions only. We give no warranty, express or implied, as to description, purity, productiveness, or any other matter of any seeds, bulbs, or plants we send out, and we will not be in any way responsible for the crop. If the purchaser does not accept the goods on these terms, they are at once to be returned.

\section{Parcels Post Rates for Seeds SIMPLE RULES FOR ORDERING BY PARCEL POST}

All Seeds, Plants, Bulbs, Roots, Poultry Supplies, Insecticides, etc., can now be sent throughout the United States by Parcel Post. On weights of more than half pound, the pound rate shown in Parcel Post Table will apply. Parcels weighing half pound or less, the rate is $1 \mathrm{c}$ for each 2 ounces or fraction thereof regardless of distance. The points further than the Second Zone on weights of over 10 pounds the charge by freight or express is usually more economical.

\section{POSTAGE RATE TABIF FOR PARCII POST PACKAGES}

Ask your Postmaster or Rural Letter Carrier to tell you what zone you are in from Petersburg, Va., then refer to the table and you will know how much postage to send for mailing.

First Pound $\begin{gathered}\text { Each Additional } \\ \text { or Fraction. }\end{gathered}$ Pound or Fraction.

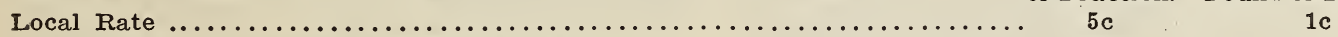

First Zone, within 50 miles of Petersburg, Va.................. $5 \mathrm{c}$ 1c

Second Zone, 50 to 150 miles from Petersburg, Va................. $5 \mathrm{c} \quad 1 \mathrm{c}$

Third Zone, 150 to 300 miles from Petersburg, Va................ $6 \mathrm{c} \quad 2 \mathrm{c}$

Fourth Zone, 300 to 600 miles from Petersburg, Va................ $7 \mathrm{c}$ 4c

Fifth Zone, 600 to 1,000 miles from Petersburg, Va................ $8 \mathrm{c} \quad 6 \mathrm{c}$

Sixth Zone, 1,000 to 1,400 miles from Petersburg, Va................. 9c $9 \mathrm{c}$

Seventh Zone, 1,400 to 1,800 miles from Petersburg, Va............. 11c 10 c

Eighth Zone, all over 1,800 miles from Petersburg, Va............. 12c $12 \mathrm{c}$ 


\section{Garden and Farm Calendar}

JANUARY.

This month is generally a period of rest for the farmer, but a wideawake man will realize that it is also the beginning of a busy Spring season, and will make preparation to push ahead the moment work begins. He will prepare hotbeds, prune trees and grape vines, top dress asparagus, haul all the manure he can get, and plow as much land as possible; get ready for the coming season and make out a list of seeds wanted for the Spring.

\section{FEBRUARY.}

If weather opens get ready for the early crops. Remember that VERY EARLY and VERY LATE crops bring the most money. Sow cabbage, tomato, lettuce and beet seed in hotbeds for transplanting, also sow a few early radish in same.

Towards the end of the month sow out doors early peas, spinach, and Spring kale; plant onion sets and lettuce plants. Prepare lawns and sow lawn grass, sow Winter oats and all grass and clover seeds, also rye for grazing; sow Canada peas.

\section{MARCH.}

Outdoor work begins this month. Select light mellow soils with Southern exposure for earliest crops. Sow all kinds of garden peas, radish, beets; also parsnips, carrots, spinach, parsley, asparagus and salsify; transplant cabbage, tomato and lettuce plants; sow in hot-beds pepper eggplant, and tomato seed. Make watermelon hills, plant Irish potatoes, asparagus and onion sets; sow Spring kale, spinach and mustard.

\section{APRIL.}

Most all crops can be sown this month; if not already done, sow peas, onions, radishes, asparagus, beets, carrots, parsley, parsnips, salsify. Bear in mind that to be a successful gardener you-must have a supply of fresh vegetables during the whole season, and to accomplish this seeds should be sown in succession: Sow celery seed in a finely prepared moist bed.

Sow all kinds of Herbs. Plant Snaps, early Corn, set out Tomato, Cabbage Lettuce and Pepper plants. Plant Irish Potatoes; prepare your land for Potatoes well, and buy only the choice, selected stock for seed as this is a very important crop. We recommend the use of fertilizer in the place of too much manure for this crop.

Bed Sweet Potato plantings. Late in the month sow Mangel Wurzel for stock. Begin planting Corn crop. Sow extra early Black-Eye Peas for market. Melons, Squash and Cucumbers can be sown, but with some risk.

\section{MAY.}

All tender plants can be sown this month. Plant Pole Beans, Snaps, Butter Beans, Sugar Corn, Melon, Squash, Cucumber, Pumpkin, Okra, and Salsify. Set out Tomato, Pepper, Eggplants and Lettuce Plants. Sow Tomato and Cabbage seed for late crop.

Set out Sweet Potato Plants, sow Millet and Cowpeas mixed for feer. This mixture yields large crops of hay and improves the land. Sow Kaffir Corn, Sugar Corn Black-Eye Peas, Soja Beans, Navy Beans and Buckwheat. Finish planting Corn, also Cotton and Peanuts. Sow Cowpeas for fallowing.

\section{JUNE.}

Summer has now opened, and farmers can push ahead without fear of frost. Continue sowing and planting all varieties of vegetables to have them come in succession, always having something for the market and table. Sow Cabbage and Tomato seed for the late crop. Plant sugar Corn for late roasting ears, also Water and Musk Melons; also Cucumbers for Pickles. Prepare for late Potatoes. Sow Beets and Pumpkins for stock food for winter. If stand of Corn crop is poor, replant with early Yellow Corn, such as Early Leaming or Early Dent. Sow Cowpeas and Millett for hay; also Kaffir Corn for chicken feed and fodder. Gather Onion crop if dry enough.

Towards end of month plant late Potatoes when suitable season offers. Plant second crop of Snaps, Butter Beans, etc.

Plant Navy Beans and Black-eye Peas for Winter use. Keep Celery bed well weeded, as the plants are very easily killed by weeds.
Prepare land well for Celery by filling trenches with well rotted manure; mix thoroughly: with soil and form even beds, selecting a moist bottom with heavy chocolate loam.

\section{JULY.}

All seeds not already sown should be put in at once Continue planting early Corn and Snaps of all kinds for late marketing. German Millet can be sown on good land. Plant out Celery plants, and if weather gets dry cover bed with fine manure to retain moisture. Also plant out late Cabbage and Tomato plants. Sow Rutabaga and early varieties of Turnips.

Finish planting late Potatoes and keep a good lookout for bugs, as they are very hard on late Potatoes. Dust with Paris Green and Slugshot at first sign of bugs. Corn can still be drilled to make fodder. Throughout the entire season your land should be kept well stirred and loosened by continual cultivating, as the moisture is better retained. If the weather should continue dry, make frequent use of your roller.

\section{AUGUST.}

This is the month for the beginning of sowing of Fall crops. Sow all varieties Turnip seeds, also Spinach and Kale. Begin sowing German Clover; sow German Clover and Turnips together, thereby making two crops on the same land.

Cultivate well your late Potatoes and keep the bugs down. Throw a furrow or two to the Celery to get fresh moist soil next to the plants.

Turn under Cowpeas and sow a fall crop on same land. Harvest all crops matured and prepare land for next crop.

\section{SEPTEMBER.}

Preparation for Winter crops should begin in earnest now by all means; sow as much German Clover as possible, as, no other crop is of more benefit to the farmer. If your Corn crop is cultivated level, it can be sown in the cornfield either for early feed in the Spring or for fallow. ing, making a good fertilizer. Gather in all crops that are ready for harvest. Sow Turnips, Kale and Spinach.

Sow Cabbage seeds for plants for Spring crop about the 21st of the month. Set our Potato Onion sets; sow Winter Oats, and begin sowing Grass and Clover. Rye and Wheat can also be sown. Hill up the Celery; save all hay and feed you can, so as not to run short in Winter.

\section{OCTOBER.}

This is about the last month any sowing should be done. Continue sowing German Clover whenever you can. A farmer's first thought should be plenty of feed for his stock; his second, how to improve his land. German Clover furnishes excellent feed in Spring when other feeds run low, and also makes a very valuable fertilizer when turned under. Gather in all crops that may still be out. Sow Winter Oats, Wheat, Grass and Clover and Rye. Plant out Cabbage plants for Spring. Plant out Trees, Vines and Strawberry plants.

\section{NOVEMBER.}

If behind time, still sow Wheat, Rye, Oats, Grass and Clover. Prepare compost heaps for Spring, and plow up all the land you can, to allow it to freeze out well during winter. Look to your lawns; sow Lawn Grass and protect it from the cold.

See that your stock is well and warmly housed, have plenty bedding, and protect your buildings in general; gather up all tools and farming imp'ements and shelter them from the weather.

\section{DECEMBER.}

Farm work proper is over for the year. You should continue plowing and adding compost heaps. The main attention should be given to your stock; see that stables are warm, and attend to the feeding yourself. Repair buildings, implements and fences. Have everything in good order, and you will be able to enjoy the joyous Christmas-tide. 


\section{MUNG BEANS-A Wonderful New Forage Crop}

The Mung Bean is a new discovery in the Cow Pea or Forage Bean family, which we believe will prove of untold benefit and value to the Southern farmer, and to the Southern farms. It is a drought resisting, quick growing, easily grown bean, and one which will do well on almost any grade of soil, and under all conditions. As a hay crop Mung Bean leads the list. The plants grow straight up, and stay straight, growing from 3 to 5 feet in height, are easily cut, easily cured, and make Hay that any animal will eat. The leaves stay on the plant much better than Cow Peas, which naturally makes the hay that much better quality. As a soil improver they are unequalled. The roots are crowded with nitrogen nodules, and will enrich the soil to a greater extent than even Cow Peas or Soy Beans. Another point of advantage is that Mung Beans will give you a stand under almost any condition. If planted in a dry spell they will stay in the ground until a rain, and will show a good germination with very little moisture.

Mung Beans should be planted in rows $2 \frac{1}{2}$ to 3 feet apart, and with one cultivation they will cover the entire field. Like other peas and beans, should be planted after the ground is warm-from May 1st to July 1st. Reports obtained from a number of farmers who have experimented with Mung Beans lead us to be absolutely confident and safe in our prediction that this wonderful bean will prove a great acquisi- tion to all farmers in Virginia and Carolina. Give them a trial, and convince yourself; results will surprise and please you.

It requires four to five pounds of seed to plant an acre. We have a limited number of pounds of Mung Bean seed to offer. Try a pound or two, and save your own seed for next year.

Mung Beans were given a fair trial in a small way in this section of Virginia during the last season, and very satisfactory results were obtained. It seems to be the general impression of those farmers who tried these beans that they would prove of untold benefit and would be a very advantageous crop to grow.

Price: Per lb. 25c; 5 lbs. $\$ 1.00$, postage prepaid.

\section{GRO=SO VEGETABLE COMPOUND}

Guaranteed Analysis: Available Phosphoric Acid, 7 to 8 per cent; Ammonia, 5 to 6 per cent; Available Potash, 5 to 6 per cent.

We are having this brand of guano especially manufactured for our truckers, to be used in the growing of their vegetable crops. Material used is of the highest quality without any effort to reduce cost, and we recommend this brand with the satisfaction of knowing that it is the best that can be used. Especially recommended for all crops growing out of the ground, which require rapid and continuous growth.

\section{Quantity of Seed Required for $\mathbf{1 0 0}$ Feet of Row}

Asparagus

Beans, Snap

Beas, Lima

Beans, Pole

Beets

Cabbage

Carrots

Cauliflower

Kale

Endive
1 ounce

1 pint

1 pint

$1 / 2$ pint

$1 / 2$ ounce

$1 / 2$ Ounce
1 ounce

$1 / 4$ ounce

$.1 / 2$ ounce $r / 2$ ounce
Egg Plant

Cucumbers

Corn.

Collards

Celery

Lettuce

Melons

Okra

Onion Seed
$\mathrm{T} / 4$ ounce

$1 / 2$ ounce

$1 / 2$ pint

1 ounce

$1 / 4$ ounce

$1 / 2$ ounce

1 ounce

2 ounce 1 ounce

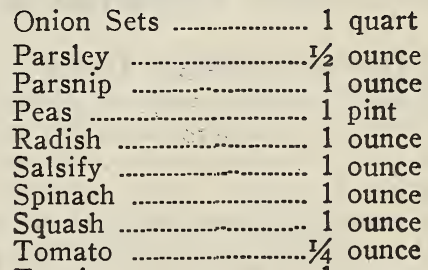

Turnip ............................ 1 ounce

\section{Length of Time Required for Seed to Germinate}

\begin{tabular}{|c|c|c|}
\hline 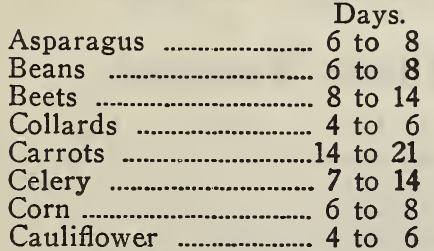 & 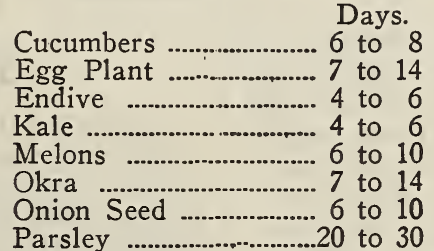 & 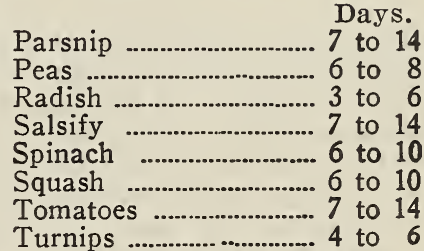 \\
\hline
\end{tabular}

Weather conditions will often cause time required to vary. The above covers the average.

\section{Number of Days}

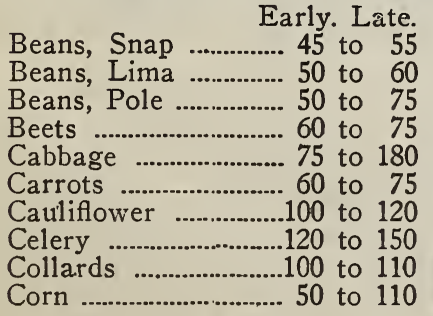

\section{Required for Vegetables to Mature}

\begin{tabular}{|c|c|}
\hline $\begin{array}{ll} & \text { Early. Late. } \\
\text { Cucumber .................. } 60 \text { to } 75\end{array}$ & $\begin{array}{lll} & & \text { Early. Late. } \\
\text { Parsnip }\end{array}$ \\
\hline Egg Plant ...............100 to 120 & Peas ............................... 40 to 75 \\
\hline Kale ......................................... 110 to & Pepper ............................... 120 \\
\hline Lettuce ..................... 40 to 90 & Radish ........................... 20 to 45 \\
\hline Melons ........................100 to 120 & Salsify ............................. 175 \\
\hline Okra & Spinach ..................... 30 to \\
\hline Onions from Seed....120 to 150 & Squash ............................. 60 to \\
\hline Onions from Sets..... 90 to & Tomatoes ...................100 to 150 \\
\hline sley .............................. & Turnips ......................... 45 to 75 \\
\hline
\end{tabular}




\section{VIRGINIA - GROWN SEED CORN}

Our stocks of Seed Corn are all Virginia grown, planted and raised especially for seed pur: poses, carefully selected, nubbed, fanned and graded, and will meet the requirements of the most fastidious corn grower. We have given our careful, personal attention to the selection of our SEED CORN, and we request all of our customers who really want good seed corn to call on us for samples, which we will gladly send free of charge, to compare with the general run of seed corn. While our prices may be a little higher, comparison will convince you that our stocks are worth the difference.

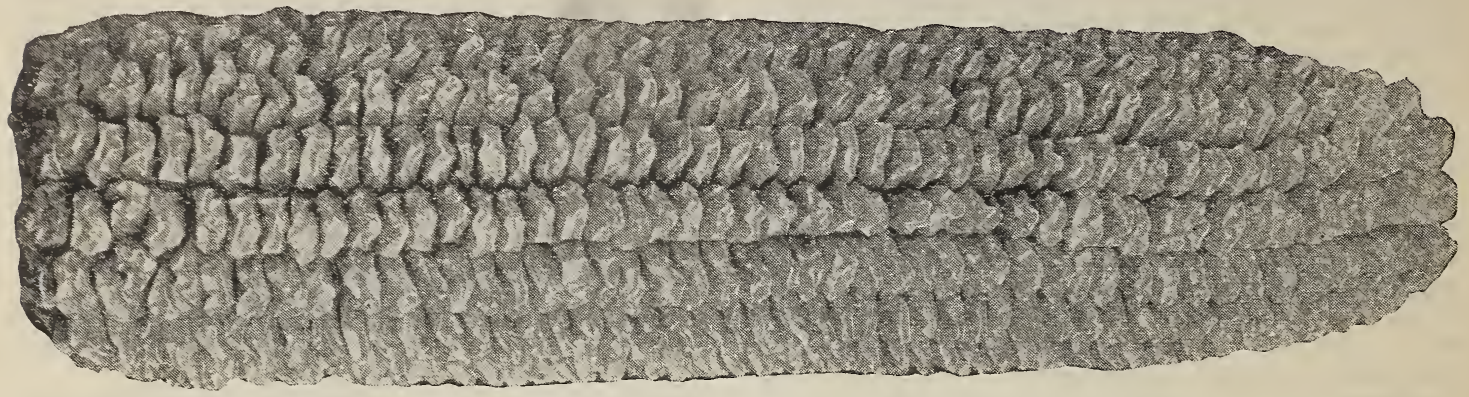

BIGGS SEVEN=EAR PROLIFIC. As its name indicates, this corn has been known to have as many as seven ears to the stalk, but we do not claim it to be a seven-ear corn; it is, however, a very prolific corn, producing a number of medium size ears to the stalk. It is pure white corn, firm and of good quality. It is also a heavy corn, weighing generally more pounds per bushel than the standard weight of 56 pounds. Growers and breeders of this variety are very enthusiastic about this corn, and it will no doubt become a favorite when it is better known. Qt. 30c; pk. $\$ 1.50$, postpaid. Not postpaid, pk. $\$ 1.25$; bus. $\$ 4$.

VIRGINIA WHITE DENT.-This is the old standard variety grown throughout Virginia. Makes large ears, deep grain and rather small cob, with heavy growth of stalk and fodder, making it also a very valuable ensilage corn. Our stock is grown by one of the most careful and successful James River farmers, and will be found true to name and of very high germinating power. Qt. 25c; pk. \$1.25, postpaid. By express, qt. $20 \mathrm{c}$; pk. $\$ 1.00$; bus. $\$ 3.50$.

EUREKA.-This corn is bred from the Cocke $\mathrm{s}$ Prolific, has larger and longer ears, but not as many to the stalk. Is considered one of the best ensilage corns for good rich bottom lands, where it will grow from 14 to 16 feet with an abundance of fodder and heavy yield of corn. This corn is extensively used throughout the North and West for ensilage. We do not recommend it for thin land. Qt. 30c; pk. $\$ 1.25$, postpaid. By express, qt. 20c; pk. $\$ 1.00$; bus. $\$ 3.50$.

HICKORY KING.-A good corn well adapted to our thin uplands, bearing three or four solid ears to each stalk. The grain is large and broad, and cob so small that a grain of the corn will completely cover the end of it. While the ears are not large enough to place this corn in the heavy yielding class, it will give better results on poor lands than any other variety. Qt. 30c; pk. $\$ 1.50$, postpaid. By express, qt. $25 \mathrm{c}$; pk. $\$ 1.00$; bus. $\$ 3.75$.
VIRGINIA ENSILAGE.-This corn makes a larger growth and more fodder than any other variety grown, and is largely planted, both North and South, for ensilage, for which purpose it is unequalled. Qt. 30c; pk. \$1.25, postpaid. By express, qt. $25 \mathrm{c}$; pk. $\$ 1.00$; bus. $\$ 3.25$.

CASEY'S PURE=BRED.-This splendid corn is fast becoming a leader in Virginia. It is a pure white, deep-grain corn, of very attractive appearance, generally bearing two well-filled ears to the stalk, and is a sure crop producer. Casey's Pure-Bred has been thorougniy tested in this territory, and we unhesitatingly recommend it to our customers for general purposes and as a prize winner. Qt. $30 \mathrm{c}$; pk. $\$ 1.50$, postpaid. By express, qt. 20 c; pk. $\$ 1.00$; bus. $\$ 3.50$.

BOONE COUNTY WHITE.-This is an early maturing, large yielding variety, suitable for uplands, and is a great favorite in some sections. It makes a large, well-filled ear with deep kernels, foliage abundant, good, strong growing stalk. Qt. 30c; pk. \$1.50, postpaid. By ex= press, qt. $20 \mathrm{c}$; pk. $\$ 1.00$; bus. $\$ 3.50$.

\section{Yellow Varieties}

IMPROVED GOLDEN DENT. - This well known and popular corn yields from two to three ears of deep golden-yellow grain, does well under general conditions, and on account of its early maturity and nutritious quality has become a very valuable corn throughout the South, especially for late planting, as it can be put in successfully after the seasun is too far advanced for the white varieties. Qt. 25c; pk. \$1.25, post= paid. By express, qt. 20 c; pk. $\$ 1.00$; bus. $\$ 3.75$.

GOLDEN BEAUTY. - This is an improved strain of the well known Golden Dent Corn, having been carefully bred and selected by a well known Virginia corn grower for a number of years, the result being larger and more uniform ears, well filled from butt to tip, very vigorous and heavy growth, and a sure cropper. A great corn for late planting. Qt. 25c; pk. \$1.25, post= paid. By express, qt. $20 \mathrm{c} ;$ pk. $\$ 1.00$; bus. $\$ 3.75$. 


\section{MAINE-GROWN SEED POTATOES WRITE FOR}

Selected Seed Stocks, grown especially for seed purposes, by the best and most careful seed potato grower in Aroostook County, Maine. Purity and quality considered before price.

Prices on Potatoes fluctuate, and are subject to market changes.

IRISH COBBLER. - The favorite above all others as an extra early market potato. The tubers are large, smooth and round, meat creamy white; very few eyes, and of fine quality; a good yielder and considered the most profitable potato for market gardeners. Per bus. $\$ 2.00 ; 10=$ pk. bag, $\$ 4.00$.

SECOND CROP IRISH COBBLER. As the name implies, this is the second crop of same year of the Maine grown Irish Cobbler, and is planted extensively by market gardeners. Being smaller in size, the second crop will plant about one-third more ground than the first crop and many truckers claim they get better resuits and more potatoes. Our stock of these potatoes is exceptionally fine, but very limited in quality. Price per bus., \$2.00;

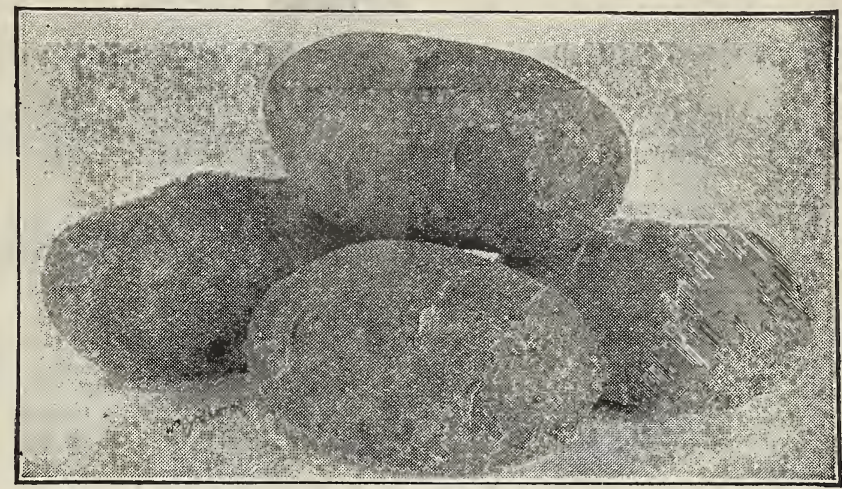

Early Ohio. per $11=$ pk. bbl., $\$ 4.00$.

RED BLISS, or TRIUMPH.-An extra early potato, round shape, pink skin, white meat, and good quality. One of the surest and most productive varieties, and highly recommended for home use, but does not sell as readily on our local markets on account of its pinkish appearance. Price per bus., $\$ 2.00 ; 10=$ pk. bag, $\$ 4.00$.

IMPROVED WHITE PEACH BLOW. - For second or late crop this potato is without equal; oblong in shape, pure white meat, pinkish skin and good eating quality. It is the heaviest yielding variety in cultivation, and is the one potato which never fails to bring results, and which will keep indefinitely. If planted in July in this locality it never fails to produce a good crop of fine potatoes. The Improved White Peach Blow is also known as the McCormirk in some localities. We cannot too strongly advise our farmers to plant this potato, if they want potatoes for winter use. Per bus., $\$ 1.75 ; 10=$ pk. bag, $\$ 4.00$.

We Will Carry a Stock of Seed Potatoes in Cold Storage for Late-Crop Plantings. Prices on Application in Season.

Seed Sweet Potatoes “CERTIFIED SEFI," In our efforts to co-operate with, and assist the Sweet Potato, which diseases have been playing havoc with our sweet potato crops in this State, we the Sweet Potato, which diseases have been playing havoc with our sweet potato crops in this State, we
are going to offer to our trade what is known as "Certified Seed." These plantings will have been grown from treated and inspected seed tubers, again examined and inspected while growing, and finally inspected and certified when the crop is harvested. This stock will be absolutely free from "Blue Stem" and other

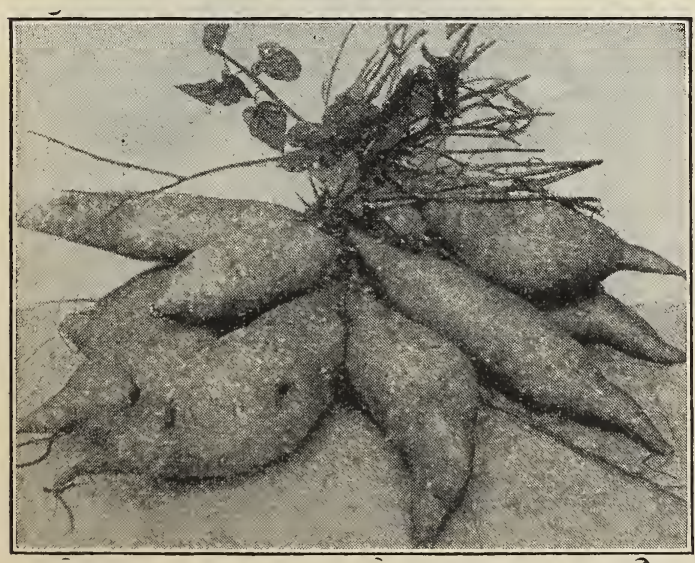
diseases of the sweet potato, and while costing a trifle more, the seed will repay the planter ten times over in increased production and better quality potato. We expect to have two varieties of this "Certified Seed," the Nancy Hall and the Porto Rico.

NANCY HALL. - A pumpkin yam of the finest quality; early maturing and good yielder.

WHITE YAM.-The standard variety for general crop purposes.

YELLOW BARK.-A dry mealy potato of fine table quality, and much desired by those who do not like a soft sweet potato.

PORTO RICO. - Considered the favorite throughout the South. A rich, deep pumpkin colored yam, very sweet, early maturing, and good producer.

Prices on Sweet Potatoes Fluctuate. Write for Quotations in Season.

All Varieties of Sweet Potato Plants in Season. 


\section{W. Grossmann \& Son's Carefully Selected Vegetable Seeds}

The following list comprises a selection of the best varieties of High Grade Vegetable Seeds - such varieties as have been tested, and tried, and found to be superior to numbers of other varieties of their kind. They are true to name, of high germination, and will bring results satisfictory to the most fastidious gardener.

\section{Asparagus}

Asparagus succeeds best in a light, warm, rich soil, with an Eastern or Southern exposure. To grow from seed, sow in drills two feet apart, covering the seed one to two inches deep, and thin out when up and growing. Keep the plants free from weeds by thorough cultivation during the Summer. These plants should then be transplanted when one or two years old to the place selected for your asparagus bed, and can be put out either in Fall or spring. One or two-year-old plants can be purchased to avoid delay of raising same.

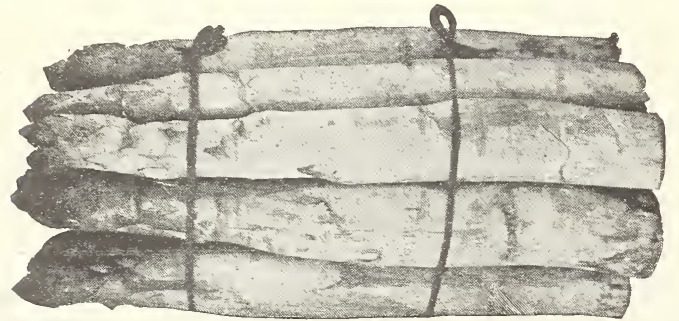

CUITURF.-Plow trenches 10 to 12 inches deep, five feet apart; scatter well rotted manure in bottom of furrow and mix with soil, cover this with a layer of soil two inches deep and give an application of pure raw bone; on this set your plants 15 inches apart in the row, spreading the roots carefully. Then cover with soil three to four inches deep. When winter comes cover the beds with stable manure, which fork in when Spring opens and earth up the beds to a further depth of about 18 inches. After the cutting season, allow the plants to grow, and during the following Winter the beds should be turned down with a plow and more manure and raw bone applied, then earthed up again to original height. This should be repeated each year during the life of the beds.

PAIMITTO-Favorite and earliest variety for Virginia. Oz. 10c; $1 / 4$ 1b. 30c; 1b. 80c, postpaid. Irot postpaid, $1 / 4$ 1b. $25 \mathrm{c}$; 1b. $75 \mathrm{c}$.

CONOVER'S COLOSSAI-A standard variety, large and tender stalks. Oz. 10c; 1/4 1b. 30c; 1b. 80c, postpaid Not postpaid, 1/4 1b. 25c; 1b. $75 \mathrm{c}$.

ASPARAGUS ROOTS-Two-year old. $\$ 1.50$ per 100 , postpaid.

\section{Artichoke}

JERUSAIIEMI-Grown from roots or tubers for stock and hog food. Plant and cultivate like potatoes; special price on large lots. Qt. 25c; pk. $\$ 1.00$, postpaid. Not postpaid, qt. $20 \mathrm{c}$; pk. $75 \mathrm{c}$; bu. $\$ 2.50$.

\section{Brussels Sprouts}

This delicious vegetable should be very much more generally cultivated in the South than it is at present. It is easily king of the cabbage family. Try it and you will never be without it.

Sow the seed in May, transplanting when large enough to $11 / 2$ feet apart in the row and cultivate as cabbage. After several hard frosts, the flavor is greatly improved. Break off the leaves in the fall to make better heads. One ounce of seed will produce 1,500 or 2,000 plants.

Price: Pkt. 5c; 0z. $25 \mathrm{c} ; 1 / 4$ lb. $60 \mathrm{c}$; 1b. $\$ 2.00$ postpaid. By express, 1b. $\$ 1.90$.

\section{Bush or Dwarf Lima Beans}

Plant in May after the ground has become warm. For the pole varieties use 10 -foot poles in center of hills, which should be about 5 feet apart. Bush varieties should be planted in rows 3 feet apart, with the beans about 12 inches apart in rows, cover about 2 inches deep. A second planting of the bush varieties should be made in June or early part of July to get a seed supply and dry beans for Winter use, as the early plantings are likely to become wormy and unfit for seed. This is also the case with snaps, black-eye peas and beans. One quart of the large plant's 100 hills; one quart of the small varieties plants 200 hills.

BURPEF'S IIMA-This is the largest of the bush varieties. Plants of upright growth, holding the beans well off the ground. Tender and of good flavor. Ib. 40c; 2 1bs. $75 \mathrm{c}$; 5 lbs. $\$ 1.50$, by mail postpaid. Not postpaid, 1b. 35c; 2 lbs. $60 \mathrm{c}$; 10 ibs. $\$ 2.50$.

HFNDERSON'S BUSH TIMA-The original well known small bush lima or butter bean; the earliest of all in maturing; heavy yielder, and of good flavor; a profitable crop for market gardeners, and very desirable for home gardens. By frequent cultivation and regularity in picking the beans, this crop can be made to bear practically the entire season. Ib. 35c; 2 lbs. 60c; 5 lbs. $\$ 1.40$, by mail, postpaid. Not postpaid, 1b. 30c; 2 lbs. $50 \mathrm{c}$; $10 \mathrm{lbs}$. $\$ 2.25$; $50 \mathrm{lbs}$. $\$ 11.00$.

FORDHOOK BUSH IIMA-Vines strong, erect, and of true bush type, holding the pods well off the ground. A heavy yielder of large, fat, tender and sweet lima beans. An acquisition to any garden. Ib. $60 \mathrm{c} ; 2$ lbs. $\$ 1.00 ; 5 \mathrm{lbs}$. $\$ 2.00$, by mail, postpaid. Not postpaid, 1b. $50 \mathrm{c}$; $2 \mathrm{lbs}$. $80 \mathrm{c}$; $10 \mathrm{lbs}$ $\$ 3.50$.

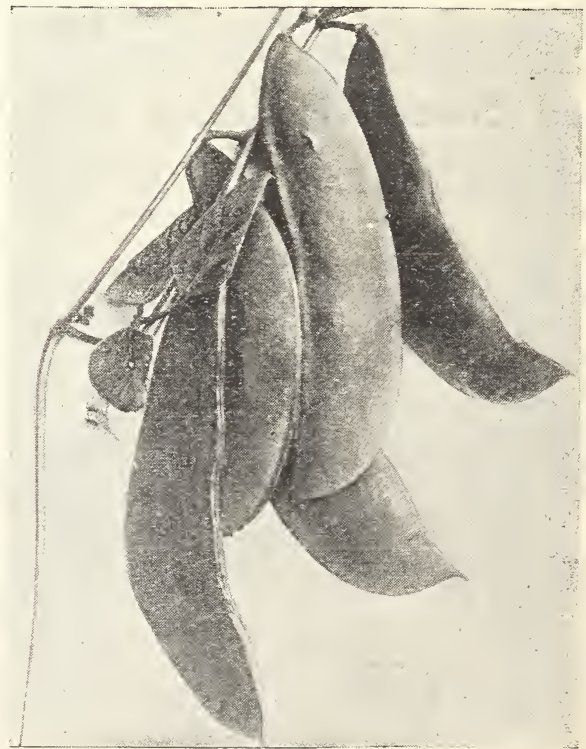

Henderson's Bush Iima. 


\section{Pole Lima Beans}

SMAII IIMLA, OP POIE BUTTER BEAN-The standard variety. Elarlier and more productive than the larger limas. Sure crop, fine quality, and a general favorite throughout the South. Ib. 35c; 2 lbs. 60c; 5 lbs. $\$ 1.40$, by mail, postpaid. Not postpaid, ib. 30c; 2 ibs. 50c; 10 lbs. \$2.25.

IMPROVED POIE IIMA-A much larger bean than the small lima, and somewhat earlier and more prolific than the standard large white lima. A good bean for general crop purposes. Ib. 35c 2 lbs. 60c; 5 lbs. \$1.40, by mail, postpaid. Not postpaid, lb. 30c; 2 lbs. 50c; 10 lbs. $\$ 2.25$.

KING OI GARDEN-Very large beans. Pods well filled, fine flavored; medium early in maturing, and a great favorite with market and home gardeners. Ib. $40 \mathrm{c} ; 2 \mathrm{lbs}$. $70 \mathrm{c} ; 5 \mathrm{lbs}$. $\$ 1.50$, by mail, postpaid. Not postpaid, 1b. 35c; 2 lbs. $60 \mathrm{c} ; 10 \mathrm{lbs}$. $\$ 2.50$.

\section{Beans-Dwarf or Bush}

One Pound Will Plant Fifty Feet of Drill.

CUITURE-Beans are somewhat tender, but it often pays to take some risks. Plant in warm, loamy soil at the beginning of settled warm weather in spring, and at intervals for succession until August. Rows may be made 2 feet apart, and the Beans planted a few inches apart in the drills, or 3 or 4 Beans in hills 6 to 8 inches apart. Cultivate and hoe frequently, always, however, when the vines are perfectly dry. In hoeing draw the soil up towards the rows of plants. For string Beans gather the pods clean as soon as fit for use.

\section{GREFN-PODDED VARIFTIES}

BIACK VATENTINE-This variety will stand more frost and unfavorable weather than any other, and is recommended to market gardeners for the very earliest crop. The pods are of a very handsome appearance; long and straight; very prolific Ib. 35c; 2 lbs. 60c; 5 1bs. \$1.25; 10 1bs. $\$ 2.25$ by mail postpaid. Not postpaid, 1b. 25c; 2 lbs. $45 \mathrm{c}$; $10 \mathrm{lbs}$. $\$ 2.00$; 50 lbs. $\$ 9.00$.

FXTRA FARIX RED VAIENTINE-This is one of the best known, and most popular beans grown by market gardeners as an extra early crop. Pods are round, thick and fleshy, and of good quality, and are generally ready to be picked seven weeks after planting. Not a stringless variety, but profitable on account of earliness and productiveness. I.b. 35c; 2 lbs. 60c; $51 \mathrm{bs}$. $\$ 1.25$; $10 \mathrm{lbs}$ $\$ 2.25$, by mail postpaid. Not postpaid, 1b. 25c; 2 lbs. 45c; $10 \mathrm{lbs}$. $\$ 2.00$; 50 1bs. $\$ 9.00$.

FUII MEASURE-This, we think, is one of the best stringless green podded varieties grown. Pods are long, round, and tender; profuse bearer, and of good flavor. We recommend the same to home gardeners and market gardeners alike. Ib. 35c 2 lbs. 60c; 5 lbs. $\$ 1.25$; 10 lbs. $\$ 2.25$, by mail postpaid. Not postpaid, 1b. 25c; 2 1bs. $45 \mathrm{c} ; 10$ lbs. $\$ 2.00$; 50 lbs. $\$ 9.00$.

GIANT STRINGIESS GREFN POD-Another exceptionally fine bean for home or market, perfectly stringless; pods longer than Burpee's Stringless; strong, vigorous grower, and a continuous bearer of delicious beans for weeks. Trb. $35 \mathrm{c} ; 2$ lbs. $60 \mathrm{c}$; 5 1bs. $\$ 1.25$; 10 lbs. $\$ 2.25$, by mail postpaid. Not postpaid, 1b. 25c; 2 lbs. $45 \mathrm{c}$; 10 lbs. $\$ 2.00$; 50 1bs. $\$ 9.00$.

BOUNTIFUI-An improvement on the old Long Green Six Weeks Snap. Pods vary from flat to round in shape; practically stringless, good quality, hardy of nature and prolific; commonly known as the Stringless Six Weeks Snap. Io. 35c; 2 lbs. 60c; 5 lbs. \$1.25; 10 lbs. \$2.25, by mail postpaid. Not postpaid, 1b. 25c; 2 lbs. 45c; 10 lbs. \$2.00; 50 lbs. \$9.00.

BURPEg'S STRINGIFSS GREFT POD-The old favorite and practically original stringless green podded bean. Absolutely stringless; quality unequalled; early in maturity. One of the best varieties for all uses. Ib. 35c; 2 1bs. 60c; 5 lbs. $\$ 1.25$; 10 lbs. \$2.25, by mail postpaid. Not postpatd, 1b. 25c; 2 lbs. 45c; 10 lbs. $\$ 2.00$; 50 1bs. $\$ 9.00$.

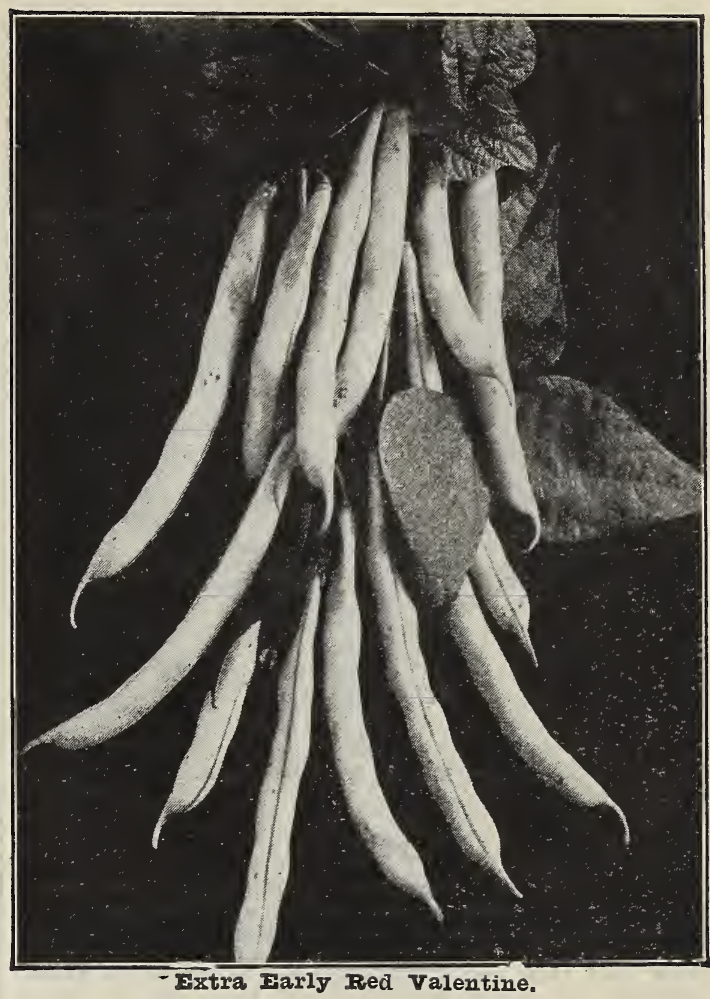

WAX OR YEIIOW-PODDED VARIFIIES

PFNCII POD BIACK WAX-The best strain of Black Wax Beans, with all the good qualities to make a first-class stringless bean for home garden and nearby market; early, prolific, and very tender; will bear for a long time if beans are kept picked. Ib. 35c; 2 1bs. $60 \mathrm{c} ; 5$ lbs. $\$ 1.25$; 10 lbs. $\$ 2.25$; by mail postpaid. Not postpaid, 1b. 25c; 2 lbs. $45 \mathrm{c}$; 10 lbs. $\$ 2.00$; 50 1bs. $\$ 9.00$.

IMPROVFD DWARF GOIDEN WAX-An old standard wax variety, which has been known for years for its fine quality, earliness, and good flavor. Pods long, fleshy, brittle and golden yellow in color: fine for home gardens. Ib. 35c; 2 1bs. $60 \mathrm{c}$; 5 lbs. $\$ 1.25$; 10 lbs. $\$ 2.25$, by mail postpaid. Not postpaid, lb. 25c; 2 1bs. $45 \mathrm{c}$; $10 \mathrm{lbs}, \$ 2.00$; 50 Ibs. $\$ 9.00$.

WFBER WAX-A somewhat later introduction, and one of the finest wax beans in cultivation. Medium early; very prolific, and exceptionally fine flavor. Not a good shipper, but one of the finest wax Not a good $60 \mathrm{c} ; 5$ lbs. $\$ 1.25$; 10 lbs. $\$ 2.25$, by mail postpaid. Not postpaid, 1b. 25c; 2 lbs. $45 \mathrm{c} ; 10$ lbs. $\$ 2.00$; 50 lbs. $\$ 9.00$

\section{Pole or Cornfield Snap Beans}

Plant in May in hills five feet apart, using an 8 10-foot pole in each hill Can also be planted in the cornfield when the corn is laid by. One pint plants 100 hills.

OTD HOMESTEAD, ON THE IEFNTUKY WONDER The earliest pole bean; enormously productive.

Long, crisp, tender pods, produced in clusters. Considered the most popular pole bean grown Ib. 35c; 2 lbs. $60 \mathrm{c}$; 5 lbs. $\$ 1.25$; 10 lbs. $\$ 2.25$ by mail postpaid. Not postpaid, 1b. 25c; 2 lbs. $45 \mathrm{c} ; 10 \mathrm{lbs}$. $\$ 2.00$; 50 lbs. $\$ 10.00$.

IAZY WIFE-Pods broad, thick, very fleshy and entirely stringless. Very prolific, the pods retaining their rich, tender qualities for a long time. Being late to mature, this is a valuable bean for the fall season. The dry beans are also used as shell beans in the winter. Ib. 35c; 2 1bs. $60 \mathrm{c}$ 5 lbs. $\$ 1.25$; $10 \mathrm{lbs}$. $\$ 2.25$, by mail postpaid. Tot postpaid, 1b. $25 \mathrm{c}$; 2 1bs. $45 \mathrm{c}$; $101 \mathrm{bs}$. $\$ 2.00$ 


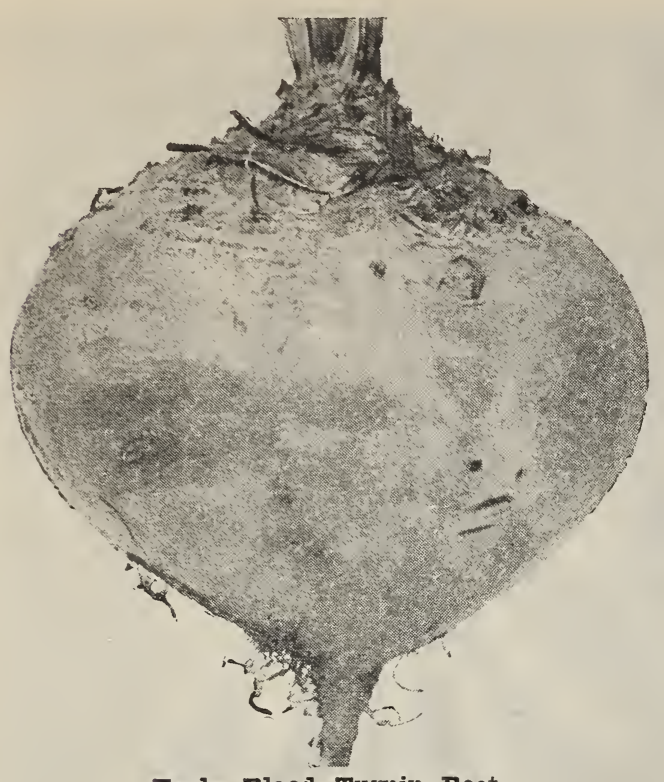

Farly Blood Turnip Beet.

\section{Beets}

For very early crops, sow in hot beds and transplant just as soon as the weather begins to warm up. For outdoor crops, sow in March and April in drills 2 to $2 \frac{1}{2}$ feet apart, covering the seed about 1 Inch, and thin out if plants are too thick in rows. Mangels or stock beets should be sown in May. Select a light, loose and deep soil for beets-one ounce sows 50 -foot drills. Six to eight pound per acre.

CROSBY'S IGYPIIAN-An extra early variety of good quality. Attractive shape, small tops. Popular with truckers for extra early market. Plit. 10c; oz. 15c; $1 / 41 \mathrm{lb}$. 30c; 1b. 85c, postpaid. By express, $1 / 4$ 1b. 25c; 1b. $75 \mathrm{c}$

FXTRA FARIY ECIIPSF-This is the most popular market beet. Globe shape, dark red, tender. Very early and highly recommended. Plet. 10c; oz. 15c; $1 / 4 \mathrm{lb}$. 30c; 1b. 85c, postpaid. By express, $1 / 4 \mathrm{lb}$. $25 \mathrm{c}$; 1b. $75 \mathrm{c}$.

CRIMSON GIOBE-Early red crimson; perfect globe smooth and clean. Fine quality for market and table. Pkt. 10c; oz. 15c; 1/4 1b. 30c; 1b. 85c, postpaid. Ву express, $1 / 41 \mathrm{~b}$. $25 \mathrm{c}$; $1 \mathrm{~b}$. $75 \mathrm{c}$.

IMPROVED FARIY BIOOD TURNIP-Dark red, uniform, smooth growing. A good variety for home use and for main crop. Very best quality, medium early. Plit. $10 \mathrm{c}$; Oz. $15 \mathrm{c}$; 1/4 1b. 30c; $1 \mathrm{~b}$. 85c, postpaid. By express, $1 / 4$ 1b. $25 \mathrm{c}$; 1b. $75 \mathrm{c}$.

DETROIT DARK RED-A fine turnip beet of dark red color, early maturity. Very attractive. Pkt 10c; Oz. 15c; 1/4 1b. 30c; 1b. 85c, postpaid. BY express, $1 / 4$ 1b. 25c; 1b. $75 \mathrm{c}$.

SWISS CHARD-This vegetable belongs to the beet family, but is grown for its leaves and stems. The leaves are used as spinach, and the stems as asparagus. Combining the two vegetables, Swiss Chard is a valuable addition to any garden. Plt. $10 \mathrm{c} ;$ oz. 15c; 1/4 1b. 30c, postpaid. By express, $1 / 4$ ib. $25 \mathrm{c}$.

STIMUPLANT.-A highly concentrated, odorless fertilizer for the vegetable and flower garden shrubs and house plants. The analysis is guaranteed, $11 \%$ nitrogen, $12 \%$ phosphoric acid, $15 \%$ potash, an ample amount of each plant food to insure a quick and strong growth of all plants, earlier maturity of garden vegetables, and a generous supply of blooms from flowering plants. 10 tablet pkg. 15c; 30-tablet pkg. 25c; 100-tablet pkg. 75c.

\section{Mangel or Stock Beet}

The great value of the Mangel or Stock Beet is: not generally known or appreciated in the South. They are easily grown and are unequalled as a milk producing food for Winter feeding. Everyone owning a cow should plant at least a small acreage in Mangels. Cultivate like beets, but thin out to about eight to ten inches apart. Six to eight pounds will sow an acre.

MAIINOTH IONG RED-Grows to an enormous size. Very easily cultivated, and the most generally used 1b. 50c, postpaid. By express, 1b. 35c;

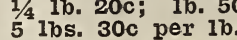

GOIDIN TANKARD-The best known and largely grown mangel. And especially recommended for dairymen on account of its milk producing properties. Well adapted to our light soils and should be grown by every one owning a cow. Oz. 10c; $1 / 4$ 1b. 20c; 1b. 50c, postpaid. By express, $1 \mathrm{~b}$. 35c; 5 Ibs. 30c per $1 \mathrm{~b}$.

\section{Iong Island Cabbage selected Iroads}

CUITURE-For the earliest setting out in the Spring, it is best to set out in February or March, plants which have been wintered over either in cold frames or out of doors. For a succession, sow the early varieties in hot-bed or cold-frames in January. or Early March. Later sow the early varieties out of doors in March or April. For winter cabbage sow in April, May or June, transplanting in July or August, to head up during the late fall and winter. Fall sowings, to make plants for setting out in the fall sow gs, to making, should be made after fall or early : Spring, should be made after shoot to seed, especially the flathead kinds. Harly varieties should be set 18 inches apart in rows $21 / 2$ to 3 feet apart; late varieties, being larger, should be set 2 feet apart in rows 3 feet apart. One ounce will produce about 2,000 plants; six ounces will make enough to set an acre. Cabbage requires good rich soil, or plenty of manure and fertilizer, and to be worked frequently and deeply.

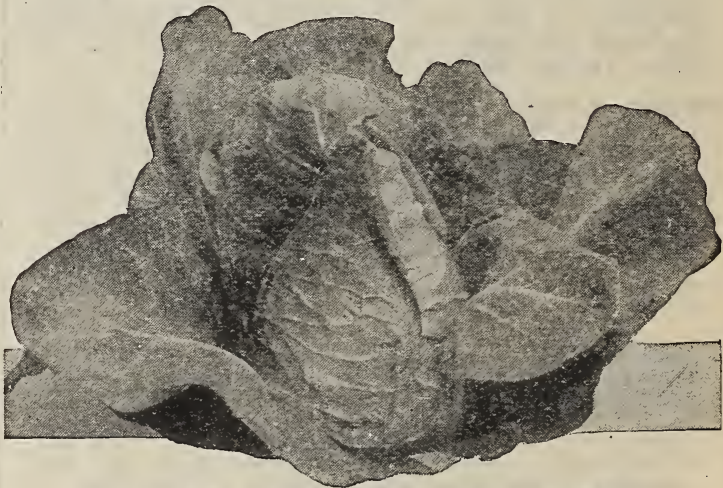

Grossmann's True Farly Jersey Wakefield.

GROSSMANN'S TRUE FARIY JERSEY WAKEFIrID-Our strain of this cabbage is unsurpassed. It has been carefully bred for years by the most careful cabbage seed grower on Long Island, strictly true to type, makes a uniform, solid head, and resists cold and unfavorable conditions. Undoubtedly the best of all extra early varieties Prt. 10c; oz. 25c; 1/4 1b. 60c; 1b. $\$ 2.00$, postpaid. By express, $1 / 4$ lb. 50c; 1b. $\$ 1.75$.

FARIY YORI-A favorite, extra early variety. Pointed head. Pkt. 10c; oz. 25c; $1 / 4$ 1b. 60c; 1b. $\$ 2.00$, postpaid. By express, $1 / 4 \mathrm{lb}$. 50c; 1b. $\$ 1.75$. FINDFRSON'S FARIY SUIVIMER-A splendid second early flat headed variety, following the Wakefield and Early Flat Dutch. Makes large, fine, round heads, very solid. Plet. $10 \mathrm{c}$; oz. 25c; $1 / 4 \mathrm{lb} .60 \mathrm{c}$; 1b. $\$ 2.00$, postpaia. By express, $1 / 4 \mathrm{lb}$. $50 \mathrm{c} ; 1 \mathrm{~b}$. \$1.75.

Our Figh Grade Sheep Ivanure, free from weeds and finely powdered, will give wonderful results in your vegetable and flower garden. 


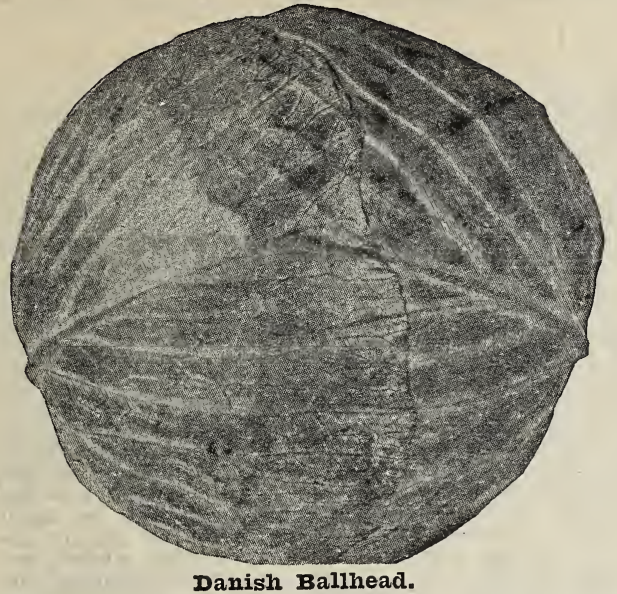

Danish Ballhead.

GROSSTMANI'S IMPROVID CHARTISTON WATEFIEID-Since the introduction of the large type Wakefield cabbage, our grower has been continuously improving our strain of this variety until he has now reached a point of perfection, which we feel can hardly be surpassed. Although a very few few days later in maturing, it is dould more solid head than makes a much better, and more sold head than ties are unequalled by any other early cabbagc almost every plant making a good, firm head. We unhesitatingly recommend Grossmann's Improved Charleston Wakefield to our truckers and gardeners as being the best early cabbage in cultivation, combining earliness, size, uniformity in tivation, combining of head. Pkt. 10c; oz. 25c; $1 / 1 \mathrm{~b} .60 \mathrm{c}$; 1b. $\$ 2.25$, postpaid. By express, 1/4 1b. $50 \mathrm{c} ; 1 \mathrm{~b} . \$ 2.00$.

FURFKA IXTRA FARIX-It is a very fine flat headed cabbage; as early as the Wakefield, heads of good size. and very uniform in growth and of good size, and very uniform in growth and

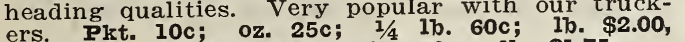
postpaid. $\mathbf{B y}$ express, $1 / 4$ 1b. $50 \mathrm{c}$; 1b. $\$ 1.75$.

GROSSMANN'S SIIORT STIMI FARIY FIAT DUTCI-The best early flat headed variety, maturing a few days later than Charleston Wakefield, making large flat solid heads, a sure header, and highly recommended to our truckers. Pkt. $10 \mathrm{c}$; oz. $25 \mathrm{c}$; 1/4 1b. 60c; 1b. $\$ 2.00$, postpaid. By express, $1 / 4$ ib. $50 \mathrm{c} ; 1 \mathrm{~b}$. $\$ 1.75$.

FARIY DRUMIIAD-An old standard variety, very popular in the South. Medium early, large, solid heads, good quality. Pkt. $10 \mathrm{c}$; oz. $25 \mathrm{c}$; $1 / 4$ 1b. $50 \mathrm{c}$; 1b. $\$ 1.90$, postpaid. By express, $1 / 4$ ib. $50 \mathrm{c} ; 1 \mathrm{~b}$. $\$ 1.75$.

ATI SFASONS-One of the best all-around cabbage grown, very large heads, and very solid; a good variety for late crop, being a splendid keeper. Plants are very vigorous and sure heading, and they withstand hot and dry weather. Pkt. 10c; . $25 \mathrm{c} ; 1 / 4$ 1b. $60 \mathrm{c}$; 1b. $\$ 2.00$, postpaid. By express, $1 / 4$ 1b. 50c; ib. $\$ 1.75$.

HENDERSON'S SUCCFSSION-A good cabbase for summer or late crop, larger and somewhat later than Henderson's Early Summer, making very solid heads of handsome appearance, keeps well for winter use. Plkt. 10c; oz. 25c; 1/4 1b. 75c;
1b. $\$ 2.50$, postpaid. By express, 1/4 1b. 65c; 1b. $\$ 2.25$.

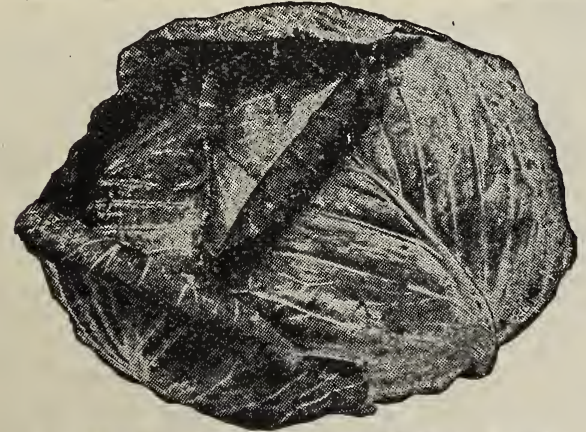

Grossmann's Premium xate Flat Putch.
IARGE IATE DRUMFEAD-A favorite winter cabbage recommended for its deep, heavy, solid and long keeping heads, has few outside leaves and is a splendid shipping cabbage. Pkt. 10c; oz. 25c; $1 / 4$ 1b. 60c; 1b. $\$ 2.00$, postpaid. By express, $1 / 41 \mathrm{~b}$. $50 \mathrm{c} ; 1 \mathrm{~b} . \$ 1.75$.

GROSSTMANT'S PRFMIUIM TATE FTAT DUTCFThis fine cabbage is without doubt the best strain for general crop or for fall cabbage; it grows to a very large size, makes hard compact heads, with few outside loose leaves, withstands hot and dry weather well, and its keeping qualities are unequalled. We can safely say every plant makes a hard head of cabbage, as in three separate tests of fifty plants each, "Our Premium" produced 47. 49 and 50 perfect heads, respectively. We recommend the same to our market gardeners and truckers as the very best winter cabbage. Pkt. 10c: oz. 25c; 1/4 1b. $60 \mathrm{c}$; 1b. $\$ 2.00$, postpaid. $\mathbf{8 y}$ express, $1 / 4$ 1b. 50c; 1b. $\$ 1.75$.

CHINESE PETSAI ON CEJERY CABBAGE - A wonderful salad plant, growing 15 or 16 inches high, somewhat resembling cos lettuce or probably more like Swiss Chard. It yields an unusual amount of most excellent salad. Sow early in the spring and again in July and August, transplanting 18 inches apart in $2 \frac{1}{2}$-foot rows. Time your spring planting so it will head before hot weather; it heads in 80 to 90 days. Pkt. $10 \mathrm{c}$; 0z. $25 \mathrm{c}$; $1 / 4$ 1b. 75c, postpaid.

DANISI BAIIIFAD CABBAGE - The heaviest cabbage for its size we have ever grown; nearly round, exceedingly solid and hard; handsome, very hardy, a sure header, a good seller, and one of the finest keepers; it is an ideal cabbage for storing $\$ 2.10$, postpaid. Not prepaid, $\$ 2.00$ per $1 \mathrm{~b}$.

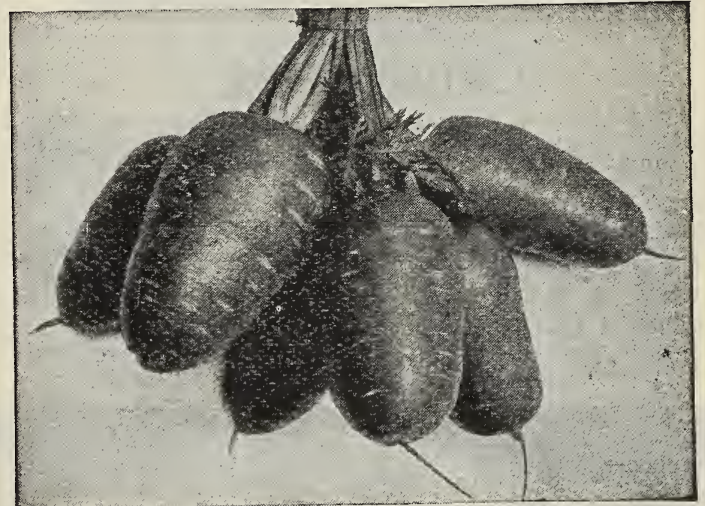

Farly Scarlet Short Iorn Carrot.

\section{Carrots}

Select a light, rich deep soil, sow in drills 15 inches apart, cover seed one-half inch and thin out to 3 inches in rows. Sow in early Spring from wor winter use put the roots in cellar or in a kiln out in the field. Carrots make a fine food for stock and should be planted extensively. One ounce sows 100 -foot drill, 3 to 4 pounds per acre.

CHANTFNAX-One of the best carrots for all purposes. Roots about 6 inches long, blunt pointed, smooth, fine grained and sweet, a heavy yielder. Pkt. 10c; oz. 15c; 1/4 1b. 30c; 1b. 85c, postpaid. By express, $1 / 4$ 10. 25c; 1b. $75 \mathrm{c}$.

IMPROVID IONG ORANGE-The standard variety for main crop. Makes long, smooth, tapering roots, of beautiful orange color, growing to good size. Fine winter variety for table, market and stock, has good keeping qualities. Pkt. 10c; oz. 15c; $1 / 4$ 1b. 30c; 1b. 85c, postpaid. By express, $1 / 41 \mathrm{~b}$. $25 \mathrm{c} ; 1 \mathrm{~b}$. $75 \mathrm{c}$.

FARTY SCARITET SHORT HORN-It is the earliest variety grown, blunt pointed, about three inches long and sweet flavored, trucker's favorite for early market. Pkt. 10c; oz. 15c; 1/4 1b. 30c; 1b 85c, postpaid. $\mathbf{B y}$ express, $1 / 4$ 1b. 25c; 1b. $75 \mathrm{c}$.

HATF TONG DANVRBS-Roots of medium length, smooth and handsome in appearance, deep orange color, crisp and tender. Pkt. 10c; $0 z_{.} 15 \mathrm{c} ; 1 / 4$ 1b. 30c; 1b. 85c, postpaid. $\mathbf{B y}$ express, $1 / 4$ 1b, $25 \mathrm{c}$; 1. $75 \mathrm{~g}$ 


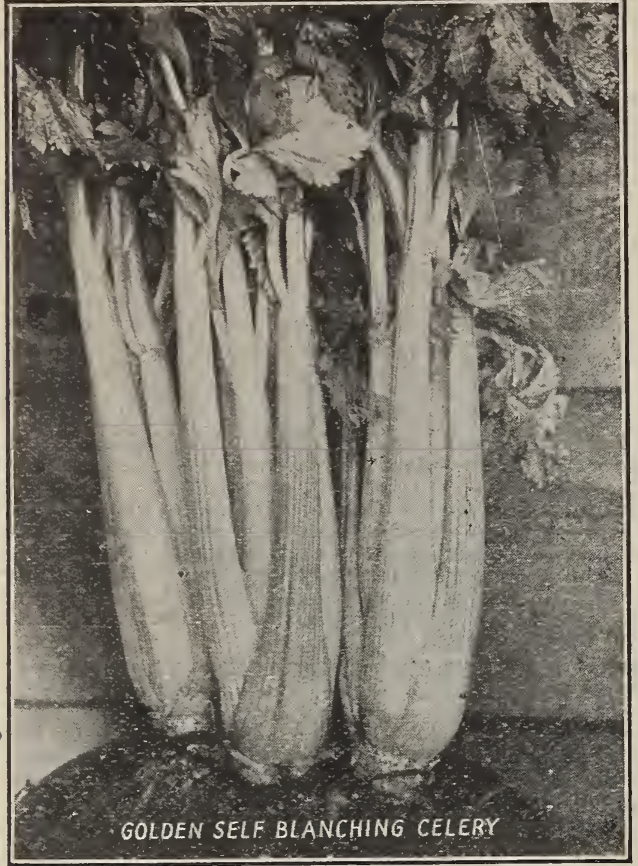

\section{Cauliflower}

Cultivate like cabbage. Sow in January or February for early crop, or May for late. Transplant to moist soil, manure heavily and water freely. When heading begins, fasten leaves over top of head to whiten.

FARIY SNOWBATI-The earliest and considered the best for the South, a sure header, making large solid, perfect heads of good quality. Plt. $25 \mathrm{c}$; oz. $\$ 3.00$, postpaid.

AUTUMN GIANT-Large late variety, heads large, white, and is a good keeper. Pkt. 10c; oz. $75 \mathrm{c}$, postpaid.

\section{Celery}

CUITURE.-Sow in February, March or beginning of April, in drills 8 to 10 inches apart, in a bed of fine, rich soil, covering one-fourth of an inch. If the soil is dry, press the earth with the back of weeds, or the young plants will be smothered. Transplant from July to October. August and September settings succeed excellently, and requires less labor. To prepare a bed, select a rich moist soil, throw out the earth to a depth of 6 inches, 4 or 5 inches wide, and put in 3 or 4 inches of well-rotted manure, dig in well, and cover with fine soil. Set the plants 6 to 8 inches apart, press the soil firmly, and earth up when the plants are large enough. Earth up two or three times, but do not let the earth get into the heart of the plant. When severe weather comes on, cover gradually with leaves, hay or straw, and place boards on top water-proof felt paper is also used. In such a bed the stalks will blanch perfectly, and may be taken out when wanted. In field culture, the plants are set out on the surface, in rows 4 feet apart, and 6 inches in the row. Celery requires frequent cultivation, and the earth drawn up to the plants as rapidly as it grows. Celeriac, or Turnip-Rooted Celery, needs no earthing up and may be planted in rows 18 inches apart. Celery seed germinates slowly; cover lightly and keep constantly moist:

WHITE PIUIME-A splendid self-blanching variety for early use. Being self-blanching, this variety requires little work, as it naturally blanches when reaching maturity. Pkt. 10c; oz. 25c; 1/4 1b. 75c; 1b. $\$ 2.00$, postpaid. By express, oz. 20c; 1/4 lb. 40c.

GIANT PASCAI-This variety is more generally grown in the South than any other variety, and is considered one of the best for fall and winter. It makes large, very solid stalks, and is very crisp and tender; a good keeping celery, Pkt. 10c; oz. $20 \mathrm{c}$; $1 / 4$ 1b. $50 \mathrm{c}$; 1b. $\$ 1.40$, postpaid. By express, $1 / 4$ 1b. $40 \mathrm{c}$; 1b. $\$ 1.50$.

WINTER QUEEN-A very desirable variety for winter, strong growth, making heavy and solid stalks, blanches creamy white, crisp and tender; splendid keeper. Plst. 10c; oz. 20c; 1/4 1b. 60c; 1b. $\$ 2.00$, postpaid. By express, $1 / 41 \mathrm{~b} .40 \mathrm{c} ; \mathrm{lb}$. $\$ 1.75$.

GOIDEN SEIF-BIANCHING-This variety excells all others in tenderness and fine flavors; makes solid stalks, 15 to 20 inches high, is self-blanching and good keeping quality; very handsome in appearance. Pkt. 10c; oz. 40c, postpaid.

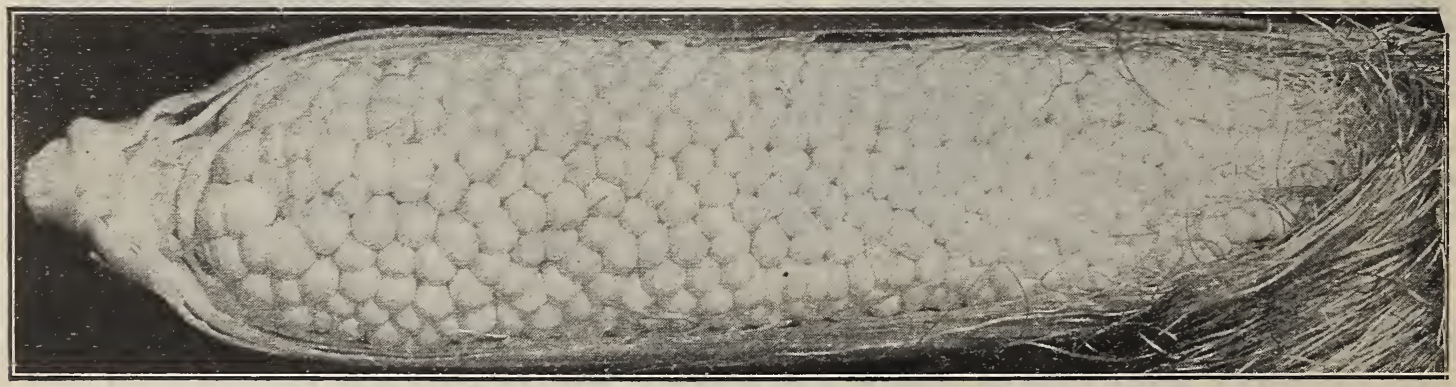

Country Gentleman.

\section{Garden Corns}

Plant early corn in rich and well-manured ground from March to middle of April. Sugar corn in May, if ground is warm. Cultivate frequently. Plant a piece about every two or three weeks to get a succession of roasting ears. The early varieties can be planted as late as July for late roasting ears. One quart plants 200 hills; eight quarts per acre.

ADAMS EXTRA E.ARIY-The earliest sweet corn in cultvation, makes a small ear and stalk, can be planted close together, and is used by our market gardeners to catch the early market. Ib. $30 \mathrm{c} ; 2$ lbs. $50 \mathrm{c} ; 5 \mathrm{lbs}$. $\$ 1.00 ; 10 \mathrm{lbs}$; $\$ 1.90$, by mail postpaid. Not postpaid, 1b. 20c; 5 1bs. $85 \mathrm{c}$; 10 lbs. $\$ 1.50$.

ADAMS IMPROVED FARIY-An improved strain of the Early Adams, with larger and more uniform ears and deeper grains; perhaps a few days later in maturing than Early Adams. I.b. $30 \mathrm{c}$ 2 1bs. 50c; 5 lbs. \$1.00; 10 1bs. \$1.90, by mail postpaid. Not postpaid, lb. $20 \mathrm{c} ; 5$ lbs. $85 \mathrm{c}$; 10 1bs. $\$ 1.50$
ADAMS EARIY-Similar to Adams Extra Early, but a little later and very much larger ears, earlier and hardier than sugar corn. a profitable corn for truckers. Ib. $30 \mathrm{c}: 2$ lbs. $50 \mathrm{c}: 5$ lbs. $\$ 1.00$; 10 lbs. \$1.90, by mail postpaid. Not postpaid, 1b. 20c; 5 ibs. 85c; 10 1bs. $\$ 1.50$.

TRUCKFR'S FAVORITE-As name implies, this is the favorite with all market gardeners and truckers, following close to Early Adams in maturity; it is larger in ears, deeper in grain, and a sure crop; a sweet and palatable corn. Trucker's F'avorite is considered the best early market corn grown. I b. 25c; 2 1bs. $40 \mathrm{c} ; 5$ lbs. 90c; 10 lbs. $\$ 1.75$, by mail postpaid. Not postpaid, lb. 20c; 5 ibs. 85c; 10 lbs. $\$ 1.50$. 


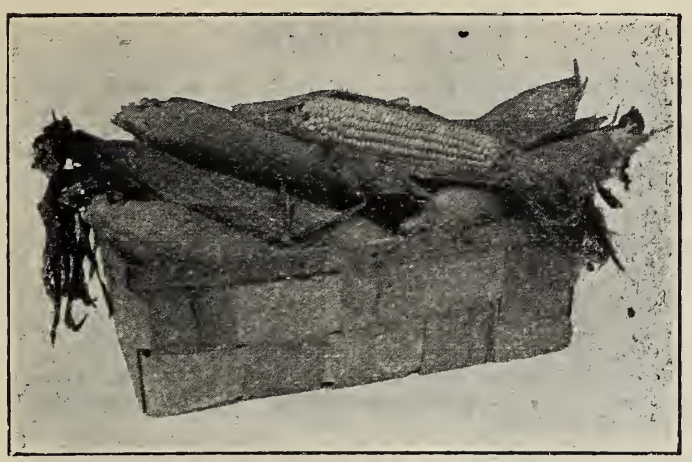

Farly White Fvergreen.

\section{Sweet or Sugar Corn}

GOIDEN BANTAM-An extra early sweet corn of very sweet and tender qualities; can be planted earlier than other sweet corns; small ear of golden yellow color; bears two and three ears to the stalk. Flet. 15c; 1b. 35c; 2 lbs. 60c; 5 1bs. \$1.25, by mail postpaid. Not postpaid, 1b. 30c; 5 lbs. $\$ 1.00$. GOIDFN GIANT BANTAM-This wonderful corn has all the fine qualities of the Golden Bantam in earliness, delicious sweet flavor, and tenderness, and rnakes an ear twice the size. Should be in every garden. I.b. 40c; 2 lbs. 75c; 5 lbs. $\$ 1.50$, by mail postpaid. Not postpaid, lb. 35c; 5 ibs $\$ 1.35$.

FARIY WHITE FVIRGREFN-An early variety of Stowell's Evergreen type, pure white kernel, deep grains and delicious in flavor; a very desirable corn for market gardeners, canners and home gardeners. Pkt. 15c; 1b. 40c; 2 lbs. 75c; 5 1bs. $\$ 1.50$, by mail postpaid. Not postpaid, 1b. 35c: 5 lbs. \$1.35; 10 1bs. \$2.50.

STOWFII'S FVPRGRFE-This is the universal sugar corn. It makes large, well filled ears, bears abundantly on good soil; and the ears remain in the green state for a long time; deep-grained and very sweet. Pkt. 15c; 1b. 40c; 2 1bs. 75c; 5 1bs. $\$ 1.50$, by mail postpaid. Not postpaid, 1b. 35c; 5 1bs. \$1.35; 10 1bs. $\$ 2.50$.

COUNTIX GENTIFMAN-One of the richest and most popular late sweet corns, has a good sized ear with small cob, long slender grains, and is especially recommended for home gardeners. Pkt $15 \mathrm{c}$; 1b. 40c; 2 1bs. $75 \mathrm{c} ; 5$ 1bs. $\$ 1.50$, by mail postpaid. Not postpaid, 1b. 35c; 5 1bs. $\$ 1.35 ; 10$ lbs. $\$ 2.50$.

\section{Pop Corn}

RICF-The most popular of all popcorns, a good yielder. Corn pops pure white and of good quality. Ib. 20c, postpaid.

MAPIFDAIE PROIIIC-A prolific, large eared variety, grains pure white and extremely tender. Ib. 20c, postpaid.

QUEFN'S GOIDEN-A very handsome yellow popcorn, large grains; pops perfectly white, and of good flavor. Generally yields four ears to the stalk. Ib. 20c, postpaid.

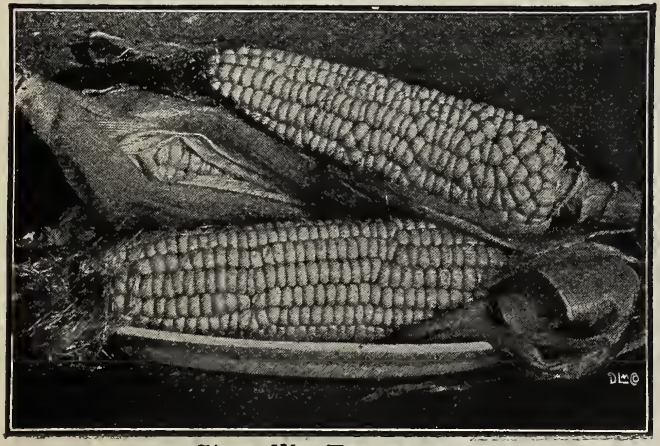

Stowell's Fvergreen.

\section{Cucumbers}

CUITURE.-For early crop, plant in hotbed, in pots or small paper boxes, or on pieces of sod, grass side down, so that they can be readily transplanted. or plant in the open ground as soon as the weather becomes setiled warm, about the end of April or during May, in hills about 4 feet apart each way. The hills should be previously prepared by mixing well-rotted manure with the soil. Put about ten seeds in each hill, and when all danger of insects is past, thin out to four plants. The fruit should be gathered when large enough, whether wanted or not, for if left to ripen on the vine, it destroys its productiveness. For pickling, plant in June or July. One ounce will plant 50 hills; two pounds, one acre.

FARIX FORTUNE-An extra early variety of uniform shape, dark green color; fast becoming a favorite with market truckers. Pkt. 10c; oz. 15c; 1/4 1b. 35c; 1b. \$1.00, postpaid. By express, oz. 10c; $1 / 4$ 1b. 25c; 1b. $85 \mathrm{c}$.

GRIIN PROIIFIC-A heavy bearing variety making fruit of medium length, and especially recommended for pickle; used extensively for late planting for pickling purposes. Pkt. 10c; oz. $15 \mathrm{c}$; $1 / 4$ 1b. 35c; 1b. $\$ 1.00$, postpaid. By express, oz. $10 \mathrm{c} ; 1 / 4$ lb. $25 \mathrm{c}$; $1 \mathrm{~b}$. $85 \mathrm{c}$.

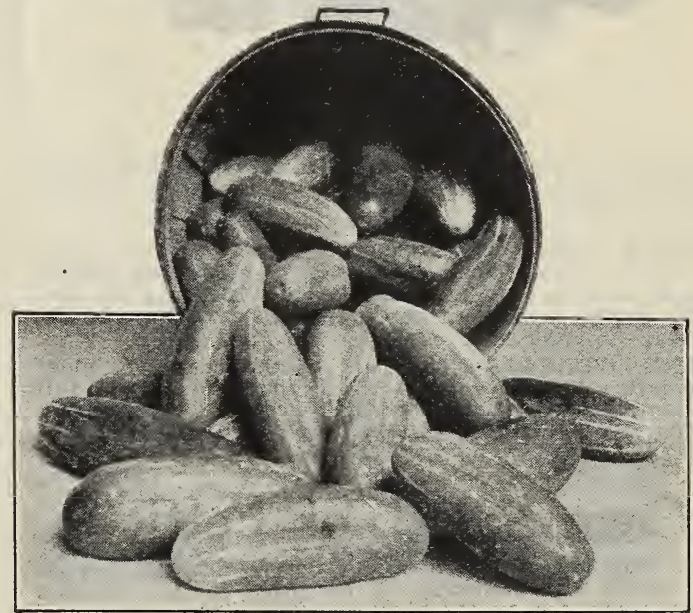

Arlington white Spine.

KIONDYKr-This variety is becoming very popular as a money-maker with our truckers; fruit is long and straight, hard and very dark green color, making a good shipping variety; early in maturing and very productive. Pkt. 5c; oz. 10c; $1 / 4$ 1b. 25c; 1b. 90c, postpaid. By express, oz. 10c; $1 / 4$ 1b. 20c; 1b. $75 \mathrm{c}$.

ARIINGTON WIITE SPINF-An improved strain of the old reliable white spine variety; the fruit is of good uniform shape, straight in growth, and rich dark green color; very popular variety with our truckers. Plkt. 10c; oz. 15c; 1/4 1b. 35c; $1 \mathrm{~b}$. $\$ 1.00$, postpaid. By express, oz. 10c; $1 / 41 \mathrm{~b}$. $25 \mathrm{c}$; 1b. 85c.

IMPROVED IONG GRFEN-This is the best cucumber for all purposes; fruit grows ten to twelve inches long; straight and dark green in color; firm and crisp; a heavy bearer and good quality; the young fruit being very desirable for pickle. Pkt. 10c; oz. $15 \mathrm{c}$; $1 / 4$ 1b. 35c; 1b. $\$ 1.00$, postpaid. By express, oz. 10c; $1 / 4$ 1b. 25c; 1b. 85c.

GFFRII, or BURR CUCUMIBFR-Small, round and prickly; used only for pickling. Pkt. 10c; oz. 20c; $1 / 4$ 1b. 50c, postpaid. By express, oz. 15c; $1 / 41 \mathrm{~b} .40 \mathrm{c}$.

DAVIS PFRTECH-This is an early variety and makes long symmetrical fruit of deep green color, which it retains for a long time; considered one of the best table varieties, and is much thought of by our truckers; highly recommended. Pkt. 10c; 0z. 15c; $1 / 4$ lb. 35c; lb. $\$ 1.00$, postpaid. By express, oz. 10c; $1 / 4$ 1b. 25c; 1b. 85c.

All Vegetable Seeds offered in this Catalogue are New Crop, 1924 growth, and produced by the most careful growers in, the country. 


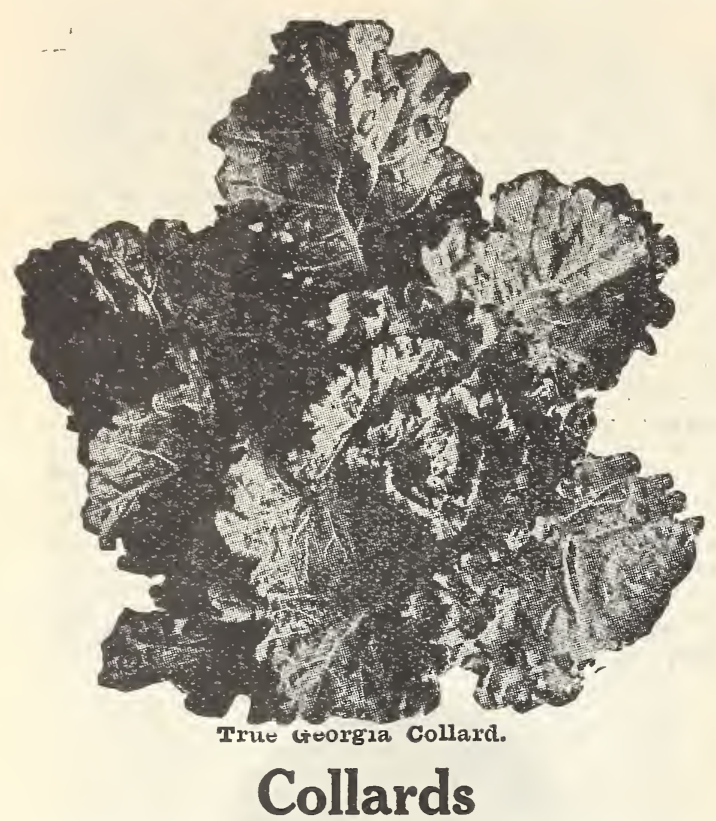

A fine winter vegetable, similar to cabbage, but does not make solid heads. Sow and cultivate like late cabbage.

NORTH CAROIINA SHORT STEM-A short stenl variety with large spreading leaves; very hardy and good flavored. Pkt. $10 \mathrm{c}$; oz. $15 \mathrm{c} ; 1 / 41 \mathrm{~b} .35 \mathrm{c}$; 1b. \$1.00, postpaid. Вy express, oz. 10c; 1/4 1b. $30 \mathrm{c} ; 1 \mathrm{~b} .90 \mathrm{c}$

TRUIS GEORGIA-The old standard and most popular collard grown throughout the South, tall and long stemmed, good flavored and very hardy. Pkt. 10c; oz. 15c; 1/4 1b. 35c; 1b. $\$ 1.00$, postpaid By express, $1 / 4$ 1b. $30 \mathrm{c}$; $1 \mathrm{~b}$. $90 \mathrm{c}$.

\section{Corn Salad, or Fetticus}

A very desirable salad; can be used like lettuce or cooked like spinach; to be sown in August and September for fall or spring use. Pkt. 10c; oz. 15c; $1 / 4$ 1b. 40c, postpaid. By express, oz. 10c; 1/4 1b. $35 \mathrm{c}$.

\section{Cress}

WATER CRESS-To be sown in the spring along edges of creek or pond. Only one sowing is along sary, as it increases and perpetuates itself: make a splendid salad and is considered quite a delicacy by a great many. Pkt. 10c, postpaid.

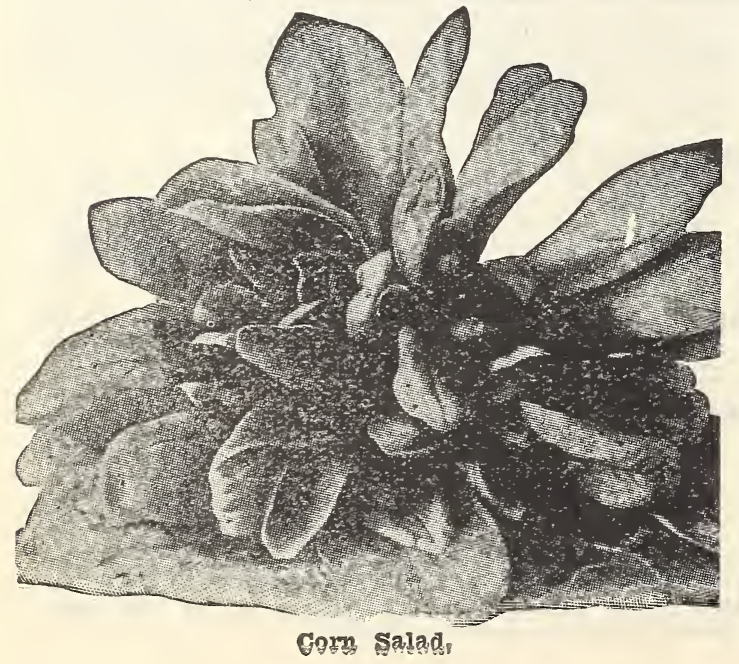

\section{Egg Plant}

CUITURT.-Egg Plant do best in a deep rlch loamy soil. In February or March sow in hotbeds, and when two inches high, transplant to good rich soil. After frost is past, set out three feet each way, and protect from bugs by dusting lightly with slugshot. One ounce will produce about 1,000 plants.

FIORIDA HIGI BUSF-Resists drought and wet weather to a wonderful degree on account of its strong, upright growth the fruits being held well off the ground. Very vigorous and productive, bearing very profusely its large purple fruits of fine shape and quality. An excellent shipper and commands high prices. Pkt. 10c; $1 / 2$ oz. 15c; oz. 30c; $1 / 4$ 1b. $\$ 1.00$, postpaid. By express, oz. $25 \mathrm{c} ; 1 / 41 \mathrm{~b}, 90 \mathrm{c}$

BIACK BEAUTY-Two weeks earlier than any other variety; produces large, lustrous, purplish fruit of fine quality; a very desirable market and shipping variety. Pkt. 10c; $1 / 2$ Oz. $15 \mathrm{c} ;$ oz. $30 \mathrm{c} ; 1 / 4$
$1 \mathrm{~b} . \$ 1.00$, postpaid. By express, oz. $25 \mathrm{c} ; 1 / 4 \mathrm{lb} .90 \mathrm{c}$. INEW YORK IMPROVID PURPIE-The best known and popular variety, vigorous and productive fruit large sized; smooth, glossy, deep purplish skin. Pkt. 10c; $1 / 2$ oz. $15 \mathrm{c} ;$ oz. 30c; $1 / 4$ 1b. $\$ 1.00$, postpaid. $\mathrm{By}$ express, oz. $25 \mathrm{c} ; 1 / 4 \mathrm{lb}$. $90 \mathrm{c}$.

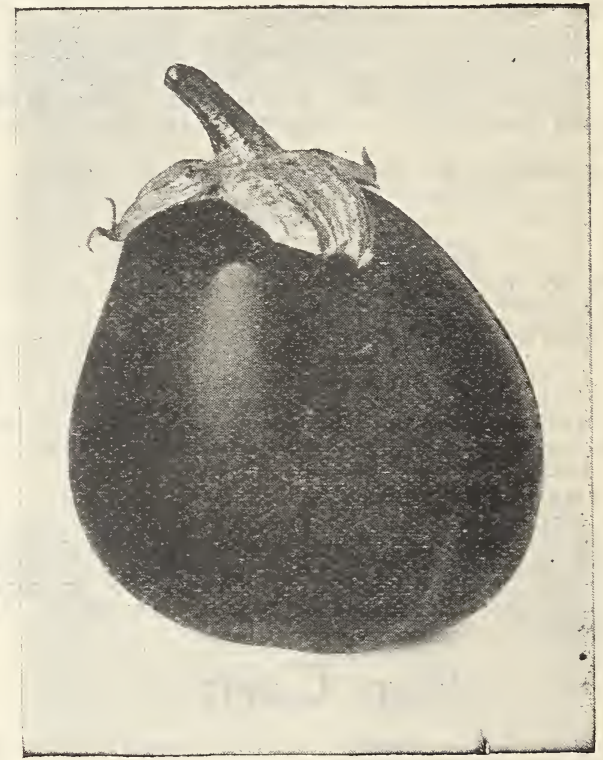

Black Beauty

\section{Endive}

CUITURE,-Sow in August in drills 18 inches apart, and thin out to blanch the heart. In dry seasons give plenty of water.

A. most excellent salad or granishing for the late summer and fall. Use same as lettuce.

GRFFN CURIED-Best variety; green, crisp and tender Pkt. 10c; oz, 20c; 1/4 1b. 75c, postpaid By express, oz. $20 \mathrm{c}$; $1 / 4 \mathrm{lb}$. $60 \mathrm{c}$.

\section{Gourds}

DIPPER-This gourd is used for making dippers. Pkt. 10c; oz. 25c, postpaid. By express, oz. 20c. NFST FGG-This gourd makes a good nest egg which lasts for years. Pkt. 10c; oz. 25c, postpaid. By express, oz. $20 \mathrm{c}$.

DISH CrOTF-The lining of this gourd is used for making dish cloths and bath sponges. Plet. 10c: oz. 35c, postpaid. Bj express, oz. $20 \mathrm{c}$.

HORSE RADISH ROOMS-25c per dozen; 50 for $75 \mathrm{c}$ : $\$ 1.25$ per $100_{1}$ postpaid 


\section{Kale}

CUITURE.-The Siberian and Scotch are the popular sort for fall sowing: a limited quantity is also sown in the spring. Sow from August 15th to October - 15 th, either broadcast or in drills 18 inches apart and give some cultivation, and they will yield greens throughout the winter. Spring or smooth Kale may be sown either in the fall or spring, making greens earlier than the winter sorts, but not of as fine quality. Spring sowings should be made in February and March. Sow 8 pounds per acre broadcast, 4 to 5 pounds in drills.

FARIY CURIED SIBERIAN-A hardy, vigorous, spreading green kale, with leaves beautifully curled around edges. Will stand the winter without protection, and is the most generally used kale for truckers and home gardeners. Oz. 10c; $y / 410$. $25 \mathrm{c}$; 1b. 75c, postpaid. By express, oz. 10c; $1 / 4$ 1b. $20 \mathrm{c}$; 1b. $60 \mathrm{c}$.

GREFN CURIFD SCOTCH, or NORFOIK-This is a dwarf spreading kale, very largely grown around Norfolk for shipping purposes. Leaves are detp green, beautifully curled and crimped. Hardy and can be grown without protection for winter. Oz. 10c; $1 / 4$ 1b. 35c; 1b. $\$ 1.00$, postpaid. By express, Oz. $10 \mathrm{c} ; 1 / 4$ 1b. $25 \mathrm{c}$; $1 \mathrm{~b} .90 \mathrm{c}$.

SPRING KAIF-A quick growing smooth leaved variety. Very generaly sown. Can be sown in fall or spring, being hardy enough to withstand the winter. Oz. 5c; 1/4 1b. 15c; 1b. 25c; 5 1bs. at $15 \mathrm{c}$ per 1b. postpaid. $5 \mathrm{lbs}$. at $12 \mathrm{c}$ per $1 \mathrm{~b}$.

\section{Kohl Rabi}

Combines the flavor of cabbage and turnips and makes a splendid dish if used when the bulbs are 2 to 3 inches thick. Sow early in hotbed and transplant and sow outside in April in rows 18 inches apart, thinning to 8 inches; for Winter use, sow in June or July. Also makes fine stock food, yielding 300 to 400 bushels to the acre.

EARIY WHITE VIFNNA-The best variety for Virginia and the South; small top, flesh white, very tender; early to mature. Pkt. 10c; oz. 25c, postpaid. By express, oz. 20c.

\section{Lettuce}

Sow the seed at intervals of three weeks during the spring for a succession of lettuce, and transplant eight inches apart in beds or rows. Sow in July and August for fall crop, in September for winter and spring crops. For winter heading transplant September plants in coldframes. One ounce produces 1,500 plants.

MAY KING-Makes large, round, solid heads. Fxtra fine for growing in coldframes. A very good all-around early lettuce. Pkt. 10c; oz. 35c; 1b. 85c.

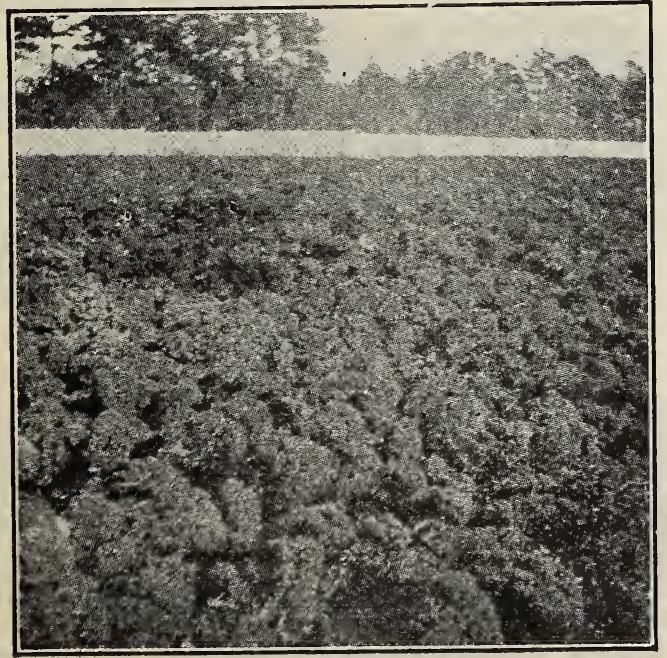

Farly Curled Siberian Kale.

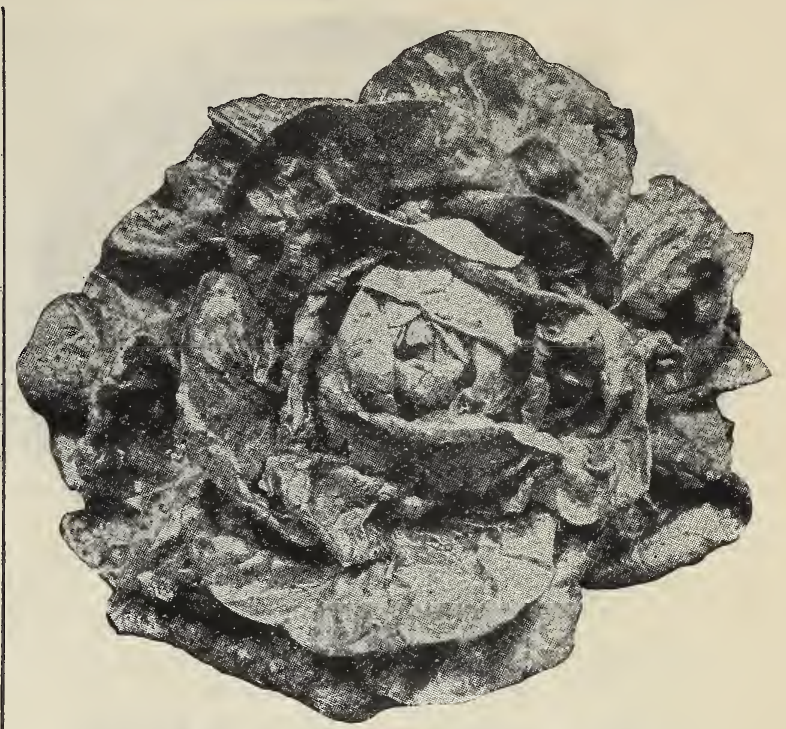

May King Iettuce.

WHITE PARIS COS-The best of the celery lettuce: forms large, light green, well folded heads of unright growth, and popular for its crispness and mild flavor. Pkt. 10c; oz. 40c, postpaid. By express, 0z. 30c; $1 / 41 \mathrm{~b}$. $85 \mathrm{c}$.

CHICKmN IFTTUCE-If you raise chickens, ycu should grow Chicken Lettuce, for it provides just the right green feed to keep them in the best of health. Unlike any lettuce you have ever grown. It does not make a heart but sends up a stalk three to four feet high fairly loaded with leaves. You can either cut the stalk or pull the leaves: in either case it keeps on growing and will yield more green feed even than rape. Although called Chicken Lettuce and recommended especially for chickens, it can be fed to any kind of stock and can be grown as economically and produced in even greater abundance than any of the green crops usually grown for feeding. An ounce of seed will produce as much green feed as the average flock of chickens can consume. Pkt. 10c: oz. 35c, postpaid.

ICFBERG-Large handsome head with bright green, curly outside leaves tinged with red. The head is hard and tightly. supported by the strongly incurved outer leaves; making exposure of the center impossible. Excellent for forcing under glass or outside planting. Quality unsurpassed. Matures in about 50 days. Plkt. $10 \mathrm{c} ;$ oz. $40 \mathrm{c} ; 1 / 41 \mathrm{~b} . \$ 1.00$, postpaid. By express, oz. 35c; 1/4 1b. 90c.

FARIY WHITE CABBAGE-This is the best allaround lettuce in cultivation. Does well for early spring, summer and fall planting. Makes fine, large, solid heads with blanched hearts. Crisp and tender. Plkt. 10c; oz. 35c; $1 / 4$ 1b. $\$ 1.00$, postpaid. By express, oz. $30 \mathrm{c}$; $1 / 4 \mathrm{lb}$. $85 \mathrm{c}$.

IMPROVF BIG BOSTON-This is a great favorit for forcing, and also does exceptionally well for outdoor planting for all seasons. Heads large, of fine appearance; crisp and tender, and of fine By express, oz. 30c; $1 / 4$ ib. $85 \mathrm{c}$

IMPROVID HANSON-One of the best suminer lettuce. Has large, solid, compact heads, tender and crisp; blanches well and withstands hot weather. Pkt. 10c; oz. 30c; 1/4 lb. $\$ 1.00$, postpaid. By express, oz. 30c; $1 / 4$ 1b. 85c.

FARIY CURIED SIMPSON-Will make a well balanced, curly, loose head; crisp and tender. Rapid growing. One of the best curled varieties. Plst. 10c; oz. 35c; $1 / 4$ 1b. $\$ 1.00$, postpaid. By express, oz. 30c; $1 / 41 \mathrm{~b} .80 \mathrm{c}$.

GRAND RAPIDS-A good curled leaved lettuce. Good for forcing, and does splendidly outdoors if sown in fall or early spring. Does not form heads but makes a large, compact cluster, crimped around edges; crisp and tender. Pkt. $10 \mathrm{c}$; oz. $35 \mathrm{c}$; $1 / 4$ 1b. $\$ 1.00$, postpaid. By express, oz. 35c; 1/4 Ib. 85c. 


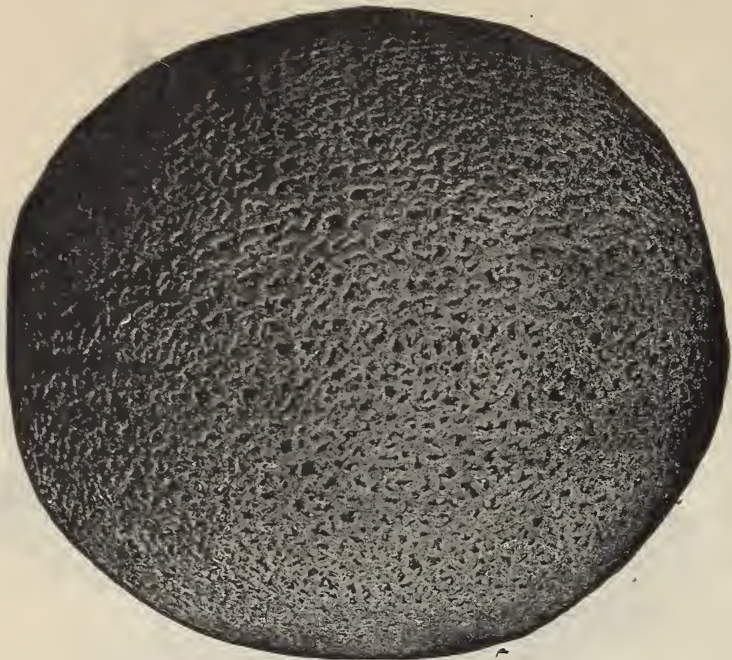

Gold Iined Netted Rock.

\section{Cantaloupe, or Musk Melon}

CUITURE.-Prepare hills 4 to 6 feet apart in a rich, moderately dry sandy soil, using well-rotted manure. When danger of frost is gone, plant 10 to 12 seeds one inch deep in each hill. To promote iruitfulness, pinch the vines when blossoming begins, and cultivate till the vines cover the ground. To combat insect attacks, dust' with ashes, lime or road-dust. Do not grow near cucumbers, squashes, etc. One ounce will plant 50 hills; two pounds, one acre.

RNIGHT-This is a splendid shipping melon. Somewhat earlier than Rocky Ford; medium sized, uniform in shape. Well netted, thick green flesh, and good quality. Oz. 15c; 1/4 1b. 40c; 1b. \$1.25, postpaid By express, oz. 10c; $1 / 4 \mathrm{lb}$. 30c; 1b. $\$ 1.00$. IMPROVED NETTE GEM-An improvement on the old favorite. Fruit uniform and larger than the Rocky Ford and quality unsurpassed. Oz. 15c $1 / 4$ 1b. 40c; 1b. $\$ 1.25$, postpaid. By express, oz. $10 \mathrm{c} ; 1 / 4 \mathrm{lb}$. 30c; 1b. $\$ 1.00$.

FARIY HACKENSACK-A large medium early melon, roughly netted, rather deeply ribbed. Splendid shipping and market melon. Fine quality. Oz. 10c; $1 / 4$ lb. 35c; 1b. $\$ 1.00$, postpaid. By express, oz. 10c; $1 / 4$ lb. 30c; 1b. $80 \mathrm{c}$.

BURRFII'S GFM-Similar in appearance to the Netted Gem, but pinkish flesh instead of green; well netted thin rind, very solid; exceptionally sweet flavored. A splendid variety for table use. press, oz. 10c; $1 / 4$ ib. $35 \mathrm{c}$; 1b. $\$ 1.00$.

TRUE ROCKY FORD-This is the most popular of all cantaloupes; small, nearly round, very thickly netted: small seed cavity, and delicious in flavor. A money-maker for truckers, and should be in every garden. Oz. 15c; $1 / 41 \mathrm{~b} .40 \mathrm{c} ; 1 \mathrm{~b}$. $\$ 1.25$, postpaid. By express, oz. 10c; $1 / 4 \mathrm{lb}$. 30c; 1b. $\$ 1.00$.

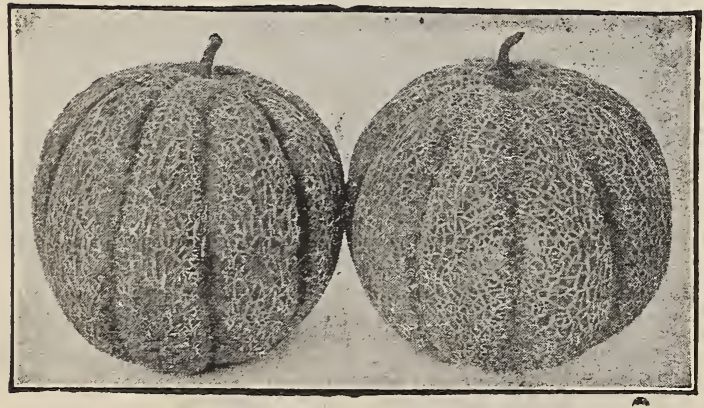

True Rocky Ford Cantaloune.
ANTP ARUNDFI-An old standard variety, great favorite for shipping; medium to large sized, well netted and fine quality. Oz. 15c; 1/4 1b. 35c; $1 \mathrm{~b}$ $\$ 1.00$, postpaid. By express, oz. 10c; $1 / 41 \mathrm{~b} .30 \mathrm{c}$ 10. $80 \mathrm{c}$.

HONGY DFW-This is certainly a delicious melon, and should be grown in every garden. The smooth, thick skin is creamy white when ripe, and so thick that the melon is practically sealed up and will keep for a month. Melon should be pulled when the blossom end is slightly soft, and kept for a few days before serving. Pkt. 10c; oz. 15c; $1 / 4$ 1b. $45 \mathrm{c}$, by mail postpaid. Not postpaid, oz. 10c; $1 / 4$ 1b. $35 \mathrm{c}$.

BANANA-Grows 18 to 24 inches long. Thick flesh and of a most delicious flavor; very sweet. Oz. 15c; $1 / 4$ 1b. 40c, postpaid. By express, oz. 10c; $1 / 4$ 1b. $35 \mathrm{c}$.

BURREII'S GOTD IINFD NFTTFD ROCK-One of the finest strains of the Rocky Ford varieties. Melons of fine grain, thick flesh and very sweet. The seed cavity very small, the flavor is exquisite. A heavy yielder. One of the sweetest melons in cultivation. Oz. 15c; 1/4 1b. 50c; 1b. $\$ 1.50$, postpaid. By express, oz. 15c; 1/4 lb. 45c; 1b. \$1.25. BURRFII'S SFIFCTYD ROCKY FORD-Grown especially for us by originator. Seed saved from selected melons only. The very finest strain of Rocky Ford obtainable. Oz. 15c; 1/4 1b. $50 \mathrm{c}$; Ib. $\$ 1.50$, postpaid. $\mathrm{By}$ express, oz. $15 \mathrm{c} ; 1 / 41 \mathrm{~b} .40 \mathrm{c}$; 1b. $\$ 1.25$.

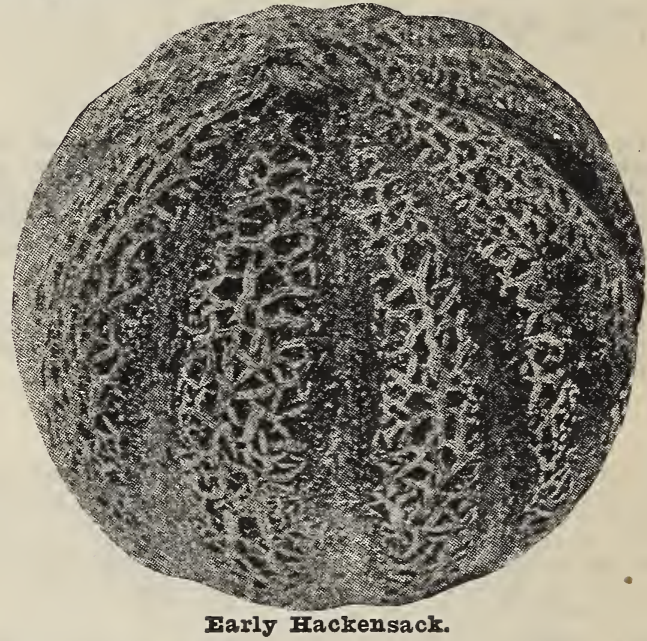

CHICAGO MARKFT-This we consider the best nutmeg melon, combining earliness of maturity large and uniform size, thickly netted skin, small seed cavity, and deep green flesh. Melons grow four to five pounds in weight. Fine quality. Oz. 10c; $1 / 4$ 1b. 35c; 1b. $\$ 1.00$, postpaid. By express, oz. $10 \mathrm{c} ; 1 / 41 \mathrm{~b}$. $30 \mathrm{c}$; 1b. $80 \mathrm{c}$.

MONTREAI MARKFT-The largest of all nutmeg sorts. Fruit round, flattened at end with very broad ribs. Flesh green and of fine quality. Oz. 10c; $1 / 4.1 \mathrm{~b} .35 \mathrm{c}$; 1b. $\$ 1.00$, postpaid. By express, oz. $10 \mathrm{c} ; 1 / 41 \mathrm{~b}, 30 \mathrm{c}$; $1 \mathrm{~b}, 80 \mathrm{c}$.

FDFN GFM-One of the best of the Rocky Ford type melons. Uniform size, very heavily netted. Green flesh, with salmon pink around seed cavity. Highly recommended for shipping, as well as for home use, Oz. 10c; 1/4 1b. 40c; 1b. \$1.25, postpaid. By express, oz. 10c; 1/4 lb. 35c; 1b. $\$ 1.10$.

\section{Leek}

CUITURE-Leek is generally considered superior to onions for soup-flavoring, etc. Sow as early as practicable in the Spring in a light, rich, moist soil in drills half an inch deep. When six or eight inches high, trim off the tops and roots, and transplant to rows one foot apart and six inches apart in the row. setting them three or four inches deep and earthing up as they grow, so that the necks will become well blanched. May also be sown in coldirames in September, and the young plants transplanted in the fall or early spring to where they are to remain. One ounce will sow about 100 feet of drill.

IARGF AMBRICAN FIAG-This is the standard variety generally used. Pirt. 10c; 0 . 25c, postpaid. 


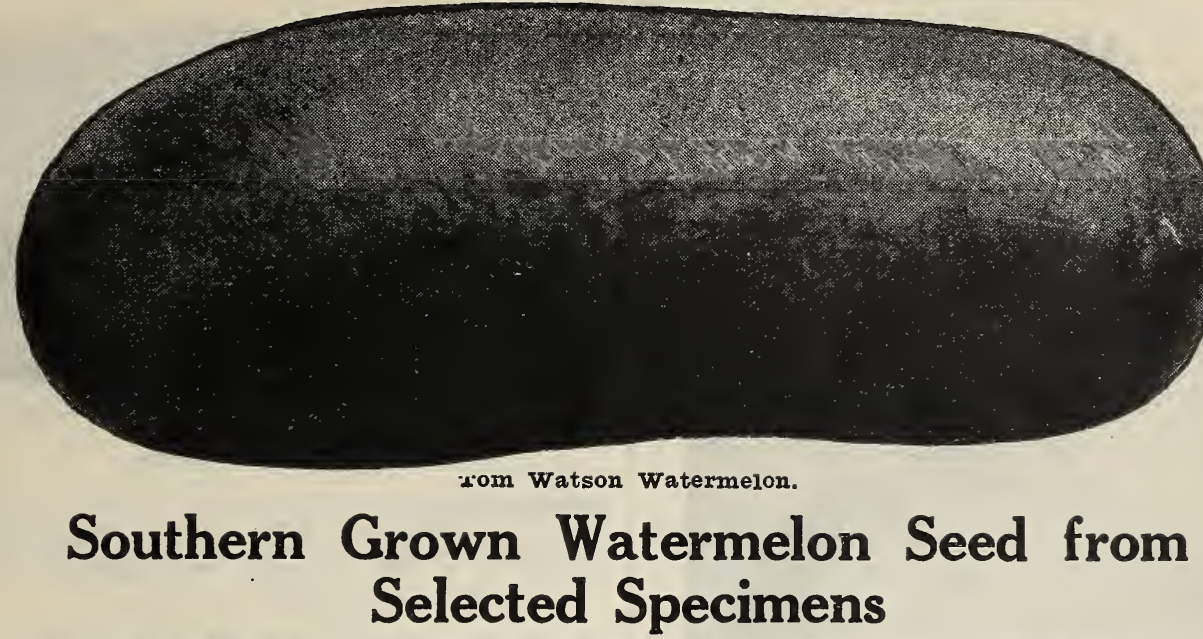

Cultivate like cantaloupes, but make the hills 12 feet apart. Do not plant near gourds or pumpkins. One ounce for 30 hills, 3 pounds for acre.

HARRIS' FARIIEST-The earliest variety grown, and a good melon for being so early. Medium large fruit, handsome in appearance, and first-class quality. Oz. 10c; $1 / 4$ 1b. 25c; 1b. $75 \mathrm{c}$, postpaid. By express, oz. 10c; $1 / 4 \mathrm{lb}$. 20c; 1b. 60c.

DUKF JONES-A large round, dark green melon. Splendid shipper: flesh dark red; sweet and juicy. Oz. $10 \mathrm{c}$; $1 / 4 \mathrm{lb}$. $25 \mathrm{c}$; 1b. $75 \mathrm{c}$, postpaid. By express, oz. $10 \mathrm{c} ; 1 / 41 \mathrm{~b}$. $20 \mathrm{c}$; 1b. $60 \mathrm{c}$.

KOIB GEM-Particularly fine shipping melon. The rind is exceptionally hard and firm. Bright red flesh and solid; heavy yielder. Oz. 10c; $1 / 41 \mathrm{~b}$. $25 \mathrm{c}$; 1b. 75c, postpaid. By express, oz. 10c; $1 / 4$ 1b. $20 \mathrm{c}$; 1b. $60 \mathrm{c}$.

IMPROVID GEORGIA RATTIFSNAKE-This is an improved strain of the old standard Rattlesnake melon, and has all the fine qualities of same, combined with larger growth and unsurpassed flavor. A splendid melon for shipping or home use. Oz. 10c; $1 / 4$ 1b. 25c; 1b. 75c, postpaid. By express, oz. 10c; $1 / 4$ lb. 20c; 1b. 60c.

TOM WATSON-Decidedly the most popular melon grown. Large, long and dark green; fruit of exceptionally fine shipping quality. Rich red, flesh solid, sweet and luscious. Good shipping, a good market, and a fine table melon. Oz. 10c; $1 / 41 \mathrm{~b}$. $25 \mathrm{c}$; 1b. 75c, postpaid. By express, oz. 10c; $1 / 4$ 1b. 20c; ib. $60 \mathrm{c}$.

KIECKIFY'S SWEFT-One of the most popular melons grown; dark green skin, thin rind, solid scarlet heart. Sweet, crisp and melting flavor. One of the best melons grown. Oz. 10c; 1/4 $1 \mathrm{~b}$. $25 \mathrm{c}$; 1b. 75c, postpaid. By express, oz. 10c; 1/4 1b. 20c; 1b. 60c.

JACKSON-An exceptionally sweet melon, and one of the best for table use. A long melon with mottled skin; ripens close to the rind. Oz. 10c; $1 / 4$ 1b. 25c; 1b. 75c, postpaid. Вy express, oz. 10c; $1 / 4$ 1b. 20c; 1b. $60 \mathrm{c}$.

BRADFORD-One of the best melons for home use or near by market, but not recommended as a shipping melon. Dark green rind with darker stripes: rather sweet. Oz. 10c; $1 / 4$ 1b. 25c; 1b. 75c, postpaid. By express, oz. $10 \mathrm{c} ; 1 / 4$ lb. 20c; $1 \mathrm{~b}$. $60 \mathrm{c}$.

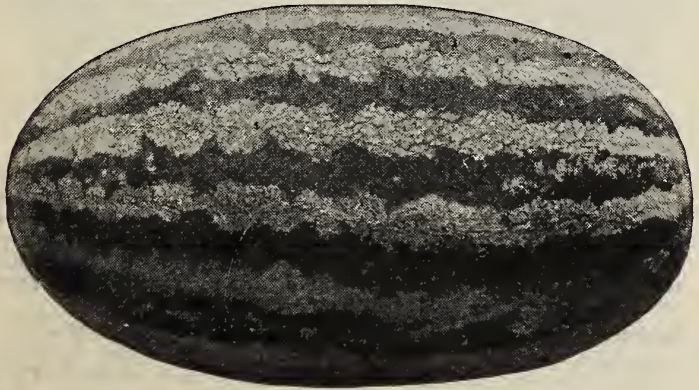

Improved Georgia Rattlesnake.
FIORIDA FAVORITE-A splendid, large, long melon. Ripens early, thin rind and deliciously sweet. A good shipper and home melon. Oz. 10c; $1 / 4$ 1b. 25c; 1b. 75c, postpaid. By express, oz. 10c; $1 / 4$ 1b. $20 \mathrm{c}$; 1b. $60 \mathrm{c}$.

JORDAN'S GRAY MONARCH-One of the largest melons grown, and a splendid shipper. Long fruit with mottled gray color, good flavor. Oz. 10c; $1 / 4$ lb. 25c; 1b. $75 \mathrm{c}$, postpaid. By express, oz. 10c; $1 / 4 \mathrm{lb}$. 20c; 1b. 60c.

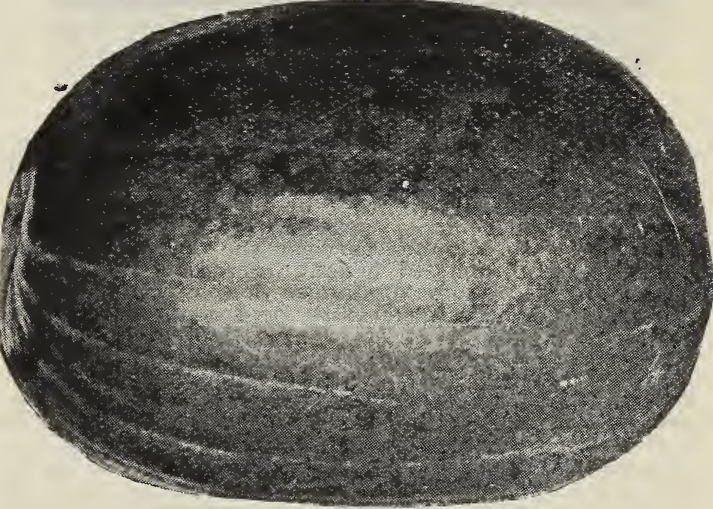

Triumph Watermelon.

TRIUMPH-A medium early, extra large melon of splendid quality. Dark green rind, with indistinet stripes; fine appearance. Flesh solid and sweet. Oz. 10c; $3 / 4$ 1b. 25c; 1b. 75c, postpaid. By express, oz. 10c; $1 / 4 \mathrm{lb} .25 \mathrm{c} ; 1 \mathrm{~b} .60 \mathrm{c}$

IRISH GRAY-As sweet as Kleckley's Sweet, but like the Tom Watson in shipping quality, size, shape and productiveness. Has a thin but tough rind, and stands shipping well. Color is a mottled greenish gray; flesh red, crisp and sweet. A great acquisition to the melon family. Oz. 10c; $1 / 41 \mathrm{~b}$. $25 \mathrm{c}$; lb. 75c, postpaid. By express, oz. 10c; $1 / 4$ 1b. 20c; 1b. 60c.

\section{Okra}

CUITORF.-When the ground has become warm, sow thickly in drills 3 feet apart, and when large enough thin out to 8 inches apart in the rows. To keep for the winter use, slice the pods when young and tender into narrow strings, string and hang in shade to dry. Ounce will sow 30 feet of drill.

WFITI VIIVIT-A very prolific variety, bearing smooth white pods of splendid flavor. The most popular okra grown. Oz. 5c; 1/4 1b. 20c; 1b. 50c, postpaid. By express, oz. $5 \mathrm{c} ; 1 / 4$ 1b. 15c; 1b. $40 \mathrm{c}$.

TAT. GRFFN-Produces in great abundance, dark green pods, of best quality. Oz. 5c; 1/4 1b. 20c; 1b. 50c, postpaid. By express, $0 z^{2}, 5 \mathrm{c}$; $1 / 4$ 1b. 15c; 1b. $40 \mathrm{c}$. 


\section{Mustard}

Grown and used like Spinach or Kale. Sow from February to April, or in September and October, broadcast or in drills. One ounce for 100-foot drill, 4 pounds per acre broadcast.

SOUTHERN GIANT CURIIED-The most popular curled mustard orown in the South: forms a great mass of leaves finely curled and crimped and of good flavor. Oz. 10c; $1 / 4$ 1b. 35c; 1b. 90c, postpaid. By express, oz. 10c; $1 / 4$ 1b. 25c; 1b. $80 \mathrm{c}$.

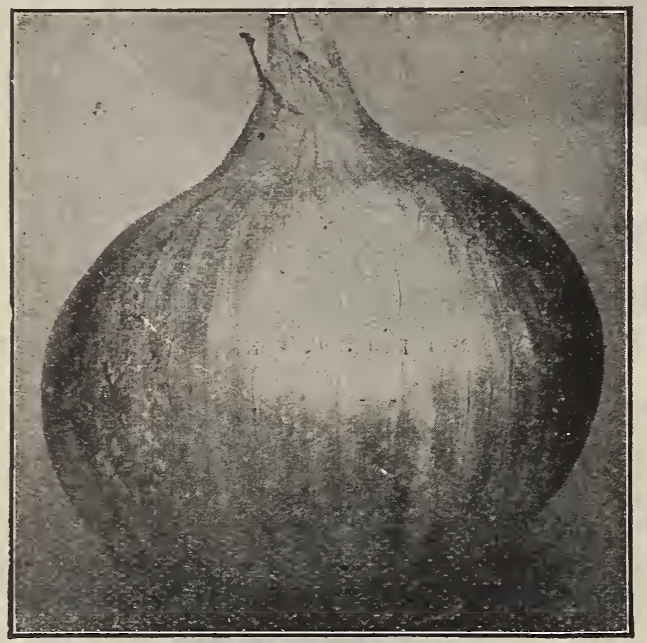

Yellow Globe Danvers.

\section{Onion}

CUITURE.-Iarge Onlons from seed.For best crop results, to grow large onions from seed the first year, sow in January and February in hot-beds and as soon as the weather opens and the sets are the size of goosequill, transplant to rows 12 inches apart and 4 to 6 inches between the onions. Transplanting is of decided benefit, increasing the yield considerably, in some instances double the yield being reported. They can also be sown in the open ground in February or March, and will make a good crop put' in at this time. The Italian, Spanish and Bermuda varieties can also be sown in August or September, and transplanted about the end of October or early in November. Five or six pounds will sow an acre.

Growing Onion sets from Seed-To grow onion sets. sow in broad, wide rows, in March or early in April, 40 to 50 pounds per acre, and keep clean of weeds. In late summer, or whenever the tops die, remove the small bulbs, buttons or sets, to a dry place, spread them out thinly on trays made of laths, piling the trays one on top of another, separated by blocks, so that the air can circulate freely between them. The larger sets should be sold for pickling, and only the smallest retained for planting.

IARGE RED WEATHERFIFID-The best known red variety. Grown to a large size, flattened on ends, but thick. A very hardy. solid and good keeping onion. Pkt. 10c; oz. 25c; 1/4 1b. 50c; 1b. $\$ 1.75$, postpaid. By express, oz. 20c; $1 / 4$ lb. $40 \mathrm{c}$; 1b. $\$ 1.50$.

YEILOW GIOBE DANVERS-The best known and most largely grown onion. Grows to good size, and ripens solid and heavy. Pkt. 10c; oz. 20c; $1 / 4$ 1b. 60c; 1b. $\$ 2.00$, postpaid. By express, oz. $20 \mathrm{c} ; 1 / 41 \mathrm{~b} .50 \mathrm{c}$; 1b. $\$ 1.75$.

EXTRA FARIY WHITE PEARI-The quickest growing of all white sorts, makes large pearly onions. Tender, mild and of excellent flavor. Seed can be sown thickly in the spring; sets raised and planted out in fall, and large onions will be ready in spring, before any other variety. Pkt. 10c; Oz. 25c; $1 / 4$ lb. $75 \mathrm{c}$, postpaid. $\mathbf{B y}$ express, $0 \mathrm{z}$. $20 \mathrm{c} ; 1 / 41 \mathrm{~b}$. $60 \mathrm{c}$.

SIIVER SKIN, or WHITE PORTUGAI-Flesh and skin pure white; flavor mild and sweet Grows to a good size and ripens early and evenly. Makes a good onion for bunching; for table use, and for pickling purposes. Pkt. $10 \mathrm{c} ; 0 \mathrm{z}$. $25 \mathrm{c} ; 1 / 4 \mathrm{lb}$. 90c, postpaid. By express, oz, 20c; $1 / 4$ lb. $75 \mathrm{c}$.

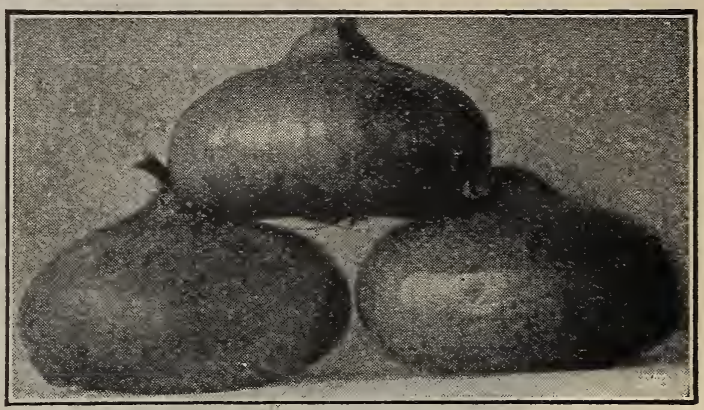

Silver Skin Onions.

PRIZETAKER-Very large and solid. Skin rich yellow, flesh pure white, sweet and mild. A $25 \mathrm{c}$; $1 / 4$ 1b. $75 \mathrm{c}$, postpaid. Not postpaid, oz. $20 \mathrm{c}$; $1 / 4$ 1b. 60c; 1 ib. \$2.25.

\section{Onion Sets}

Prices on Onion Sets Fluctuate. Current-Prices on Request.

YEIIOW DANVERS-Qt. 25c; 4 qts. 75c; pk. $\$ 1.25$, postpaid. By express, qt. 20c; peck $\$ 1.70$; bushel of 32 Ibs. $\$ 4.00$.

RED WETHERSFIEID-Qt. 25c pk. $\$ 1.50$, postpaid. By express, qt. $20 \mathrm{c}$; pk. $\$ 1.25$; bushel of 32 los. $\$ 4.00$.

SIIVIR SKIN-Crop almost total failure. Quality poor. Write for prices.

\section{Parsley}

CUTTURב.-For spring seeding, sow in February, March or early in April. Soak a few hours, and then sow in rows a foot apart, and cover about half an inch. Parsley is slow to germinate, sometimes two or three weeks in coming up. One ounce will sow 150 feet of drill.

CHAMPION MOSS CURISD-Beautifully curled and crimped, and the favorite for garnishing and flavoring. Pkt. 10c; oz. 15c; 1/4 1b. 40c, post. paid. Bj express, oz. 10c; $1 / 4$ ib. 30c.

PIAIN, or SIIOOTH IEAVID-A very hardy variety; somewhat stronger in flavor than the curled. Pkt. 10c; Oz. 15c; 1/4 1b. 40c, postpaid. By ezpress, oz. 10c; $1 / 4$ 1b. $30 \mathrm{c}$.

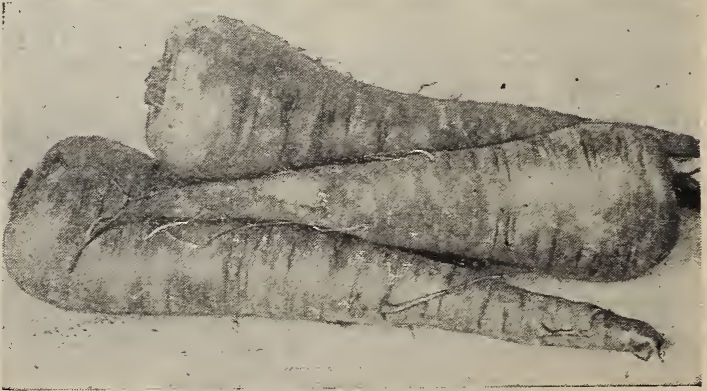

Sugar or Holiow Crown Parsnip.

\section{Parsnip}

CUITURF,-A rich sandy loam, deeply worked, is the best for parsnips. Sow in the spring, in drills eighteen inches apart, and cover lightly, Parsnip seed is very slow in germinating, especially when the ground is dry. When two inches high, thin out to 4 or 6 inches apart. One ounce will sow 200 feet of drill; five pounds to the acre.

IMPROVID SUGAR or IOIIOW CROWN-The standard variety; smooth, tapering roots, and of good flavor. Fine for both table and stock. Pkt. 10c; oz. 15c; $1 / 4$ 1b. $35 \mathrm{c}$; 1b. \$1.00, postpaid. B express, oz. 10c; $1 / 4$ 1b. $25 \mathrm{c} ; 1 \mathrm{~b}$. $85 \mathrm{c}$. 


\section{Garden Peas}

CUITURF.-Peas succed best in light, rich loamy soil which has been manured the previous season. Plant the smooth varieties in the spring as soon as the ground can be worked, in rows 3 to 4 feet apart, 2 inches deep, giving the taller vareties me rows. The wrinkled varieties are tender, and should be planted later every two weeks. The dwarf varieties can be planted in rows $2 \frac{1}{2}$ to 3 feet apart. Peas grown as a market crop are rarely ever staked, but when the taller varieties are grown for private use, it is a good plan to sow them in double rows and stake with brush. They should be kept clean and the with brush. growth. One and a half bushels are required to plant one acre, one quart to plant 100 feet of drill.

The smooth varieties of garden peas are much hardier, and will stand cold weather and adverse climatic conditions better than the wrinkled varieties, hence they can be sown much earlier. Wrinkled varieties are sweeter, and of better flavor, but should not be seeded until ground has obtained a certain degee of warmth.

\section{SMOOTH VARIFTIES}

EXTRA EARIY AIASKA-This is probably the best of all smooth extra early varieties. Pods are well filled, good length, and of beautiful green color which they retain longer than other varieties. Ib. 30c; 2 lbs. 50c; $10 \mathrm{lbs}$. \$2.25, by mall postpaid. Not postpaid, 1b. 25c; 2 1bs. $40 \mathrm{c} ; 10$ lbs. \$2.00; 50 lbs. \$9.00.

PHITADEIPHIA EXTRA EARIY-The old standard extra early variety. Very hardy, withstanling late frost, a good bearer. Pods medium lon of attractive light green color. Ib. $30 \mathrm{c} ; 2$ 13s. $50 \mathrm{c} ; 10 \mathrm{lbs}$. $\$ 2.25$, by mail postpaid. Not postpaid, 1b. 25c; 2 lbs. $40 \mathrm{c}$; $10 \mathrm{lbs} . \$ 2.00$; $50 \mathrm{lbs}$. $\$ 9.00$.

IIRST AND BEST-A very desirable strain of extra early smooth peas, and popular with truckers. Has practically the same characteristics as the Philadelphia Extra Early, but claimed by some truckers to be rather more prolific. Ib. $30 \mathrm{c}$; lbs. $50 \mathrm{c}$; $10 \mathrm{lbs}$. $\$ 2.25$, by mail postpaid. Not postpaid, 1b. 25c; 2 lbs. $40 \mathrm{c}$; $10 \mathrm{lbs}$. $\$ 2.00$; $50 \mathrm{lbs}$. $\$ 9.00$.

AMEFR-A much larger podded and more prolific strain of the original Alaska pea, ripening only a few days later than the extra early, varieties. Very popular with market gardeners, and a splendid pea for home gardens. Ib. 30c; 2 1bs. 50c; $10 \mathrm{lbs}$. $\$ 2.25$, by mail postpaid. Not postpaid, lb. $25 \mathrm{c} ; 2 \mathrm{lbs}$. $40 \mathrm{c}$; $10 \mathrm{lbs}$. $\$ 2.00$; 50 lbs. $\$ 9.00$.

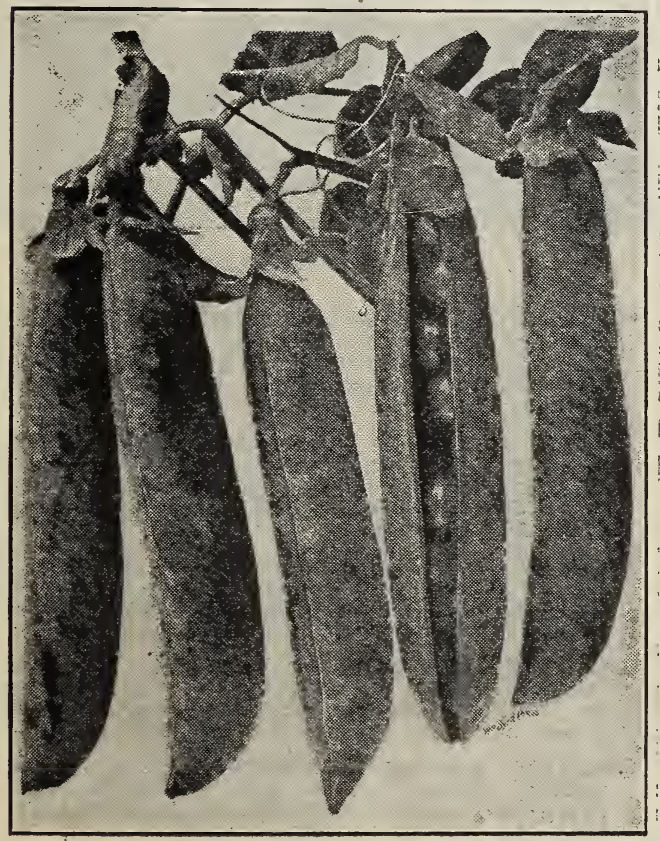

Futra Barly Alaska.
MARROWFAT-A big yielder for midsummer and late crop. The pods contain four or five peas each are about three inches long, full to the ends. Not as sweet as the wrinkled varieties, but undoubtedly the most productive of all garden peas. Ib. 25c; 2 lbs. 40c; 10 lbs. \$1.75, by mail postpaid. Not postpaid, 1b. 20c; 2 lbs. $35 \mathrm{c}$; $10 \mathrm{lbs}$. $\$ 1.50$; 50 1bs. $\$ 7.00$.

\section{WRINKIED VARIFTIES}

GRADUS, or PROSPERITY-One of the best early varieties. Pods are large, well filled, and of unsurpassed quality. Can be sown somewhat earlier than most wrinkled varieties; should be in every garden. Ib. 30c; 2 lbs. 50c; 5 lbs. \$1.00, by mall postpaid. Not postpaid, 1b. 25c; 2 lbs. $40 \mathrm{c}$; 10 lbs. \$1.75; 50 lbs. $\$ 7.50$.

THOMAS IAXTON-A large podded, early variety, and good quality; hardy, strong grower, bearing abundantly for a long time. A market gardener's favorite. Ib. 30c; 2 lbs. $50 \mathrm{c} ; 5 \mathrm{lbs}$. $\$ 1.10$, by mail postpaid. Not postpaid, 1b. 25c; 2 1bs. 40c; 10 1bs. \$1.75; 50 1bs. $\$ 8.00$.

TrLFPHONE-The most popular of all wrinkled varieties for general crop; very large pods, of a dark green color; a heavy yielder, and peas are of fine sugary flavor. Ib. 30c; 2 ibs. 50c; 5 lbs. $\$ 1.00$, by mail postpaid. Not postpaid, 1b. $25 \mathrm{c}$ : 2 lbs. $40 \mathrm{c}$; 10 lbs. $\$ 1.75 ; 50$ lbs. $\$ 7.50$.

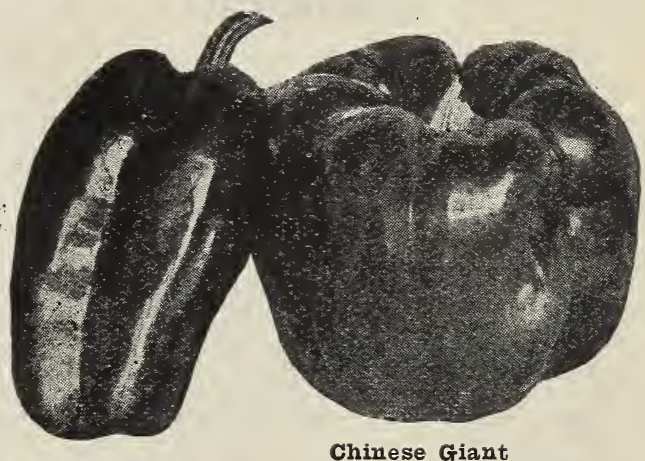

Ruby Giant

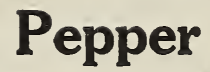

CUITURE.-SOW in hot-bed in February or March, and transplant to open ground in May in rows 2 to 3 feet apart, 15 inches between the plants: or when the ground becomes warm, sow in open ground and set out as above. When about six inches high, apply liquid manure or some good fertilizer.

CHINESE GIANT-An enormous, sweet pepper growing from 12 to 15 inches in circumference. lific. Flesh tender, mild and sweet very proslicing like tomatoes or stuffed as mangoes. Very desirable. Pkt. 10c; oz. 50c; $1 / 41 \mathrm{lb}$. $\$ 1.50$, postpaid. By express, oz. 40c; $1 / 4 \mathrm{lb}$. $\$ 1.25$.

PIMIENTO-This is the mildest-flavored of all peppers, is entirely free of the pungent flavor which so many consider undesirable, is heart-shaped, perfectly smooth, bright scarlet color and very productive. Plkt. 10c; oz. 40c; $1 / 41 \mathrm{~b}$. \$1.25, postpaid. By express, oz. $35 \mathrm{c} ; 1 / 4 \mathrm{lb}$. $\$ 1.00$.

IARGE BEII or BUII NOSE-An old standard sweet pepper. Ripens early and uniformly. Flesh of excellent quality and largely used in saluds. press, oz. 35c; $1 / 4$ 1b. $\$ 1.00$.

IONG RED CAYrNNE-The standard hot pepper. Making long, slender, bright red pods about s to 4 inches long. Used in the green and ripe state for pickling and seasoning. Plkt. 10c; oz. $35 \mathrm{c}$; $1 / 4$ 1b. $\$ 1.25$, postpaid. By express, oz. 30c; $1 / 4$ 1b. $\$ 1.00$.

RUBY GIANT-Not quite as large as Chinese Gian: but very attractive in appearance and very prolific. Flesh mild and sweet. Plst. 10c; oz. 40c $1 / 4$ ib. $\$ 1.25$, postpaid. By express, oz. 35c; $3_{1 / 1}$ 1b. $\$ 1.00$.

RED CHIII-A splendid hot pepper for making sauce and pepper vinegar. Pods grow about an inch long, and when ripe have a brilliant scarlet color Very prolific. Pkt. 10c; oz. 40c; $1 / 41 \mathrm{~b}$. $\$ 1.25$, post. paid. By express, $0 z, 35 \mathrm{c}$; $1 / 4 \mathrm{lb}, \$ 1.00$. 


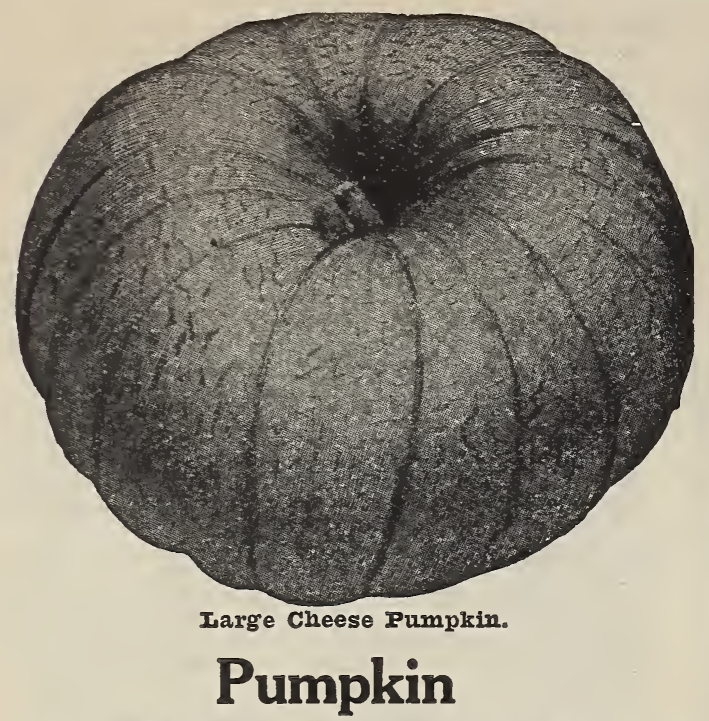

CUITURF.-Plant in May, in hills 8 to 10 feet apart, mixing well-rotted manure, in each hill. Put 8 to 10 seeds in each hill, and cultivate till the vines get strong, when they should be thinned out, leaving two or three of the strongest in each hill. When planted in corn plant at the same time as the corn, in every fourth row, 10 to 12 feet apart in the rows letting the hill of pumpkins take the place of a hill of corn. One ounce will plant 20 hills; three pounds, one acre.

CASHAW or CROOKNFCK-A fine table pumpkin and equally good for stock. Large and very productive; meat is rich yellow, tender and of the best flavor. Ours is the green striped type preferred by Southern growers and is as fine as can be had anywhere or at any price. Pkt. 5c; oz. 10c; $1 / 41 \mathrm{~b} .30 \mathrm{c}$; 1b. $\$ 1.00$, postpaid. Not prepaid, $90 \mathrm{c}$ per $1 \mathrm{~b}$.

IARGF CHFFSF-An exceedingly large pumpkin for both table and stock. Very thick flesh; sweet and of fine quality and a good keeper. Oz. 10c; $1 / 4$ 1b. 25c; 1b. 75c, postpaid. By express, oz. 10c $1 / 4$ 1b. $25 \mathrm{c}$; 1b. $65 \mathrm{c}$.

VIRGINIA MAMMIOTH-This is undoubtedly the finest pumpkin raised; growing to an enormous. size; its keeping qualities are unexcelled and it is adapted to most any climate or soil. Fruit is ovalshaped. Rich golden color; flesh of fine flavcr and a very desirable pumpkin for table as well as stock use. Oz. 10c; $1 / 4$ 1b. 35c; 1b. $\$ 1.00$ postpaid. By express, oz. 10c; $1 / 41 \mathrm{~b}$. 25c; $1 \mathrm{~b} .80 \mathrm{c}$

SUGAR or PIF-A small sweet pumpkin used mainly for making pies. Oz. $10 \mathrm{c}$; $1 / 4$ 1b. 35c; 1b. $\$ 1.15$ postpaid. By express, oz. 10 c; $1 / 4$ 1b. 30c; 1b. $\$ 1.00$.

CORNFIFID PUMPKIN-Used mainly for stock feeding. Planted in cornfields making enormous crops with little cultivation. Oz. 10c; 1/4 1b. 25c 1b. 75 c, postpaid. By express, oz. 10c; $1 / 4$ 1b. 20c; 1b. $60 \mathrm{c}$.

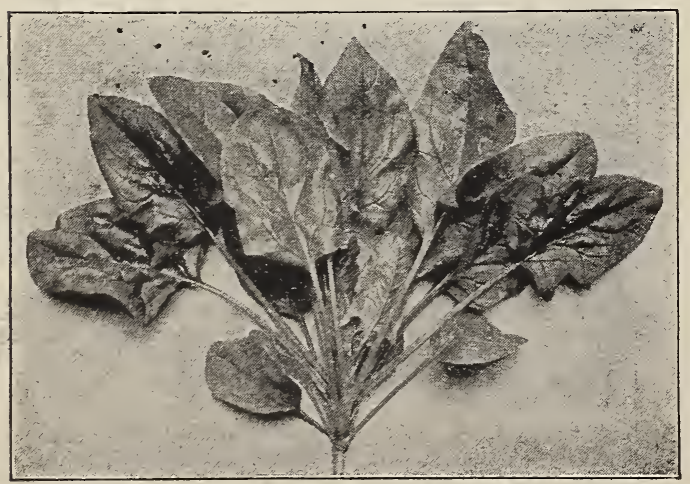

Spinach.

\section{Spinach}

Sow early in spring in rich soil in drills 1 inch deep, two feet between the rows. For winter or spring crop, sow in September and October. One ounce for 100 -foot drill; 20 pounds to an acre.

KING OF DENMARI-This new variety of spinach is quite an acquisition to any garden. Grows considerably larger than other varieties and is very slow to go to seed. Should be sown as a successor to the other early varieties, as it remains longer in edible condition than any other spinach. Give it a trial. Per oz. 10c; 1/4 1b. 25c, post. age prepaid.

NORFOIK SAVOY OI BIOOMSDAIE-The best variety for fall or spring seeding. Quick growth. hardy; beautifully curled leaves. Oz. 10c; $1 / 41 \mathrm{~b}$. 20c; 1b. 40c, postpaid. By express, oz. 10c; $1 / 4$ 1b. $15 \mathrm{c}$; 1b. $35 \mathrm{c}$; $51 \mathrm{bs}$. at $30 \mathrm{c} 1 \mathrm{~b}$.

\section{Radish}

To be tender and crisp, Radishes must be grown quickly, and this requires rich soil and moisture. Begin as early as possible in spring and sow at intervals of about 10 days in a light, rich, deeply worked soil. Can also be forced in hot-beds. For fall and winter sow in August and September. One ounce sows fifty feet.

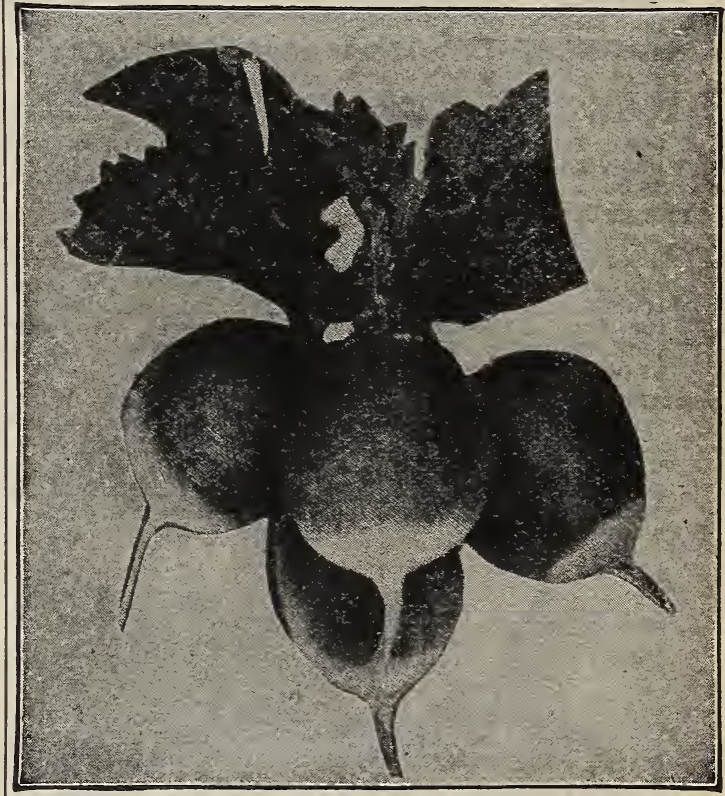

Farly Scarlet White Tip.

PARIY FORCING SCARZFT GIOBF-The earliest radish and best for forcing. Small top, bright red color. Beautiful appearance. Oz. 10c; 1/4 $1 \mathrm{~b}$. roc; 1b. 85c, postpaid. By express, oz. 10c; $1 / 3$ 1b. $25 \mathrm{c} ; 1 \mathrm{~b} .75 \mathrm{c}$.

FARIY SCARIFT TURNIP-A quick growing round red radish with small top. Crisp and tende:r. A good variety for outdoor planting. Oz. 10c; $1 / 4$ 1b. 30c; 1b. 85c, postpaid. By express, oz. 10c; $1 / 4$ 1b. 25c; 1b. $75 \mathrm{c}$.

FRFNCH BREAKFAST-A white tipped olive shaped variety, and one of the best forcing radish. Oz. 10c; $1 / 4$ ib. $30 \mathrm{c}$; 1b. $85 \mathrm{c}$, postpaid. $\mathbf{B y}$ express, oz. 10c; $1 / 4$ 1b. 25c; 1b. $75 \mathrm{c}$.

FARIY WIITY TURNIP-Pure white turnip shaped radish. Early in maturity and of good flavnr. Oz. 10c; 1/4 1b. 30c; 1b. $85 \mathrm{c}$, postpaid. $\mathbf{B y}$ express, oz. 10c; $1 / 4$ 1b. 25c; 1b. $75 \mathrm{c}$.

GOIDFN GIOBE SUMNPR-The best summer radish. Round shape, golden yellow in color. Crisp and tender. Withstands hot weather. Oz. 10c; $1 / 4$ 1b. 30c, postpaid. By express, oz. 10c; $1 / 4$ 1b. $25 \mathrm{c}$; $1 \mathrm{~b} .75 \mathrm{c}$. 


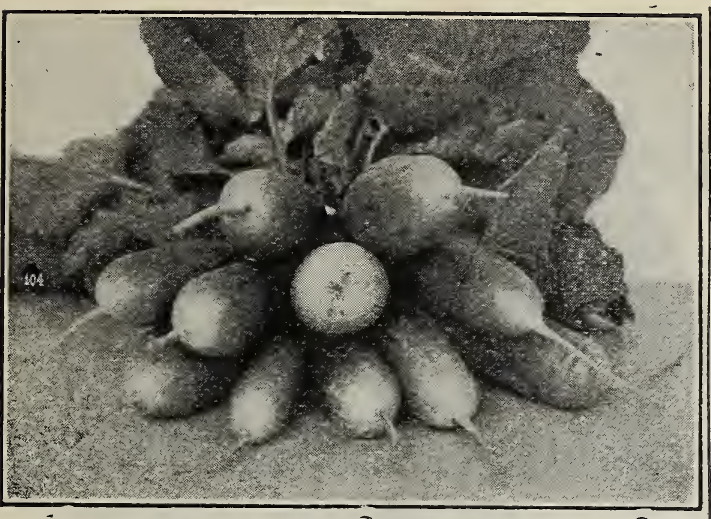

Rose China Winter Radish.

FARIY WHITE TIPPID SCARIET-Very ea: $1 y$, round shape, scarlet roots with white tip; attractive appearance. Quality crisp, tender and mild. A favorite with truckers. Oz. 10c; $1 / 4 \mathrm{lb}$. $30 \mathrm{c}$; 1b. 85c, postpaid. By express, oz. 10c; $1 / 4$ 1b. 25c; 1b. $75 \mathrm{c}$.

CRIMSON GIANT GIOBE-A large early variety. Round with deep crimson color. Tender and crisp.

\section{B-K Helps You In Many Other Ways}

B-K is a sodium hypochlorite. It is non. poisonous, clean and clear. It has the advantago of being 10 times more effective as a germ killer than undiluted carbolic acid, yet it contains no poison or acid and is safe to use anywhere that infectious diseases have to be prevented or con. quered. B-K has been used and recommended by Dairy and State Authorities, Agricultural Colleges, etc., for over 10 years and is used extensively by breeders. Our MONEY BACK GUARANTEE on every package.

Send for Free Bulletins on Stock and Poultry Diseases-Dairy Sterilizing

Powltry Disease Control-

Bulletin 213F "Poultry Health and Profts."

Ceneral Information-

Bulletin $317 \mathrm{E}$ "145 Farm Uses for B-K Germ Killer" Retained Afterbirth-

Bulletin 756 "A Safe Easy Way to Remove Afterbirth."

Calf Scours

Bulletin $136 \mathrm{H}$ "Calf Scours, Treatment and Preveation."

Abortion- $32 \mathrm{~K}$ "Prevention and Control of Abortion."

Hog Diseases -

Bulletin 147F "Hog Sanitation."

DAIRY STERILIZING

General Information-

Bulletin 320C "Better Milk."

Bottles-

Bulletin 116G "Will She Boast of the Purity of Your Milk?"

Cans-

Bulletin 87K "Amazing Adventure, of 3 Milk Cans."

Milking Machines-How to Use Successfully-

Bulletin $124 \mathrm{M}$ "How to Purify Milking Machines"" "What Happens in Your Barn?"

Separator-

Bulletin 112J "A Clean Purified Separator."

GENERAL LABORATORIES, Madison, Wis.

Manufacturers of B-K Germ Killer, Knox-Out Fly Sprast, Udder Health Ointment for Caked Bag and Garget Be-Health Sterilizer for Apiaries.

B-770 D-25R-1-25

\section{Salsify, or Oyster Plant}

CUITURz.-Sow in March or April in a rich light, deeply worked soil, in rows 18 inches apart, and thin out to 4 to 6 inches. Do not use coarse or fresh manure; it will make the roots ill-shaped and uneven. Cultivate often to keep down weeds. It is perfectly hardy, and may remain out all winter. Can also be sown in May and June, provided we get seasonable weather or boards be used to get the seeds up and shade the young sprouts until they get well established. One ounce will sow 50 feet of drill; eight pounds to one acre.

MAMMOTY SANDWICH ISIAND-Largest and best variety, vigorous grower, with long, large white tapering roots. Oz. 20c; $1 / 4 \mathrm{lb} .75 \mathrm{c}$; 1b. $\$ 2.50$, post paid. By express, oz. $15 \mathrm{c} ; 1 / 41 \mathrm{~b} .60 \mathrm{c} ; 1 \mathrm{~b}, \$ 2.25$.

\section{Squash, or Cymling}

CUITURF.-After danger of frost is past, plant in a warm well-pulverized, rich soil mixing wellrotted manure with the soil in each hill plant eight or ten seeds to the hill; the bush varieties 4 to 6 feet apart, the running sorts 8 to 10 feet. When well grown, thin out, leaving three of the strongest plants in each hill. Summer sorts, one ounce to forty hills, four to six pounds to an acre: winter sorts, one ounce to ten hills, four to five pounds to an acre.

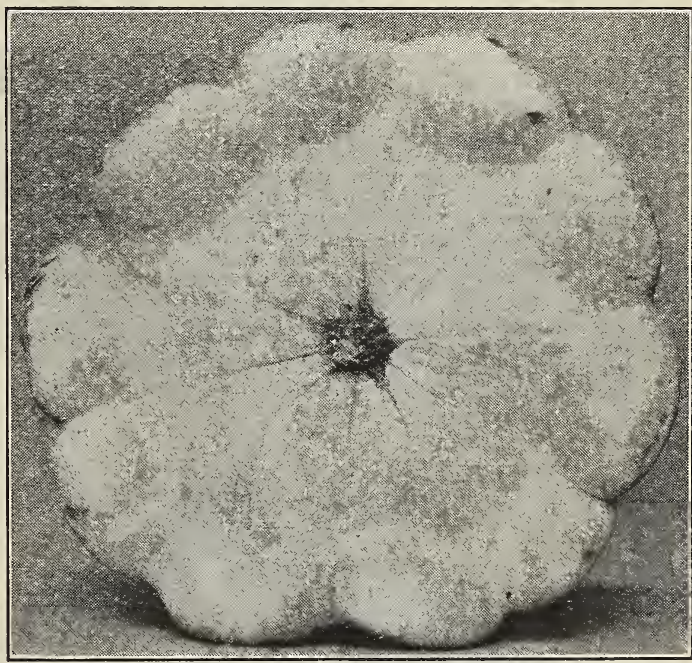

Early White Bush Squash.

EARIY WHITE BUSH-The standard White Bush squash or cymbling. Grown extensively by truckers for main crop. Very prolific and an excellent shipper. Also grown for hog feed. Oz. 10c; $1 / 4$ 1b. $35 \mathrm{c}$; 1b. $90 \mathrm{c}$, postpaid. By express, oz. $10 \mathrm{c}$; $1 / 4$ lb. $25 \mathrm{c} ; 1 \mathrm{~b} .75 \mathrm{c}$.

HUBBARD SQUASH-One of the best winter varieties. Heavy fruit of bright orange flesh, tine grains, sweet and richly. flavored, a good keeper. and unsurpassed for squash pies. Oz. 10c; $1 / 41 \mathrm{~b}$. $35 \mathrm{c}$; 1b. $\$ 1.00$, postpaid. By express, oz. 10c; $1 / 4$ lb. $30 \mathrm{c}$ lb. $90 \mathrm{c}$.

EARIIEST PROIIFIC WHITF BUSF-This is the earliest variety of white bush squash in cultivation, and is a money-maker for truckers. Ten days earlier than Early White Bush; same growth and same shape fruit. Scallops not so pronounced flesh thick, firm and very tender. Oz. 15c; $1 / 4$ 1b. 50c; 1b. $\$ 1.50$, postpaid. By express, 0z. I0c; $1 / 4$ lb. $40 \mathrm{c} ; 1 \mathrm{~b}$. $\$ 1.35$.

GIANT SUMIMER CROOKNECK-A beautiful variety for summer crop, bears early and continues through the summer. Of true crookneck type; rich golden yellow color. Thickly warted and of excellent table qualities. Oz. 10c; $1 / 41 \mathrm{~b} .35 \mathrm{c} ; \mathrm{Ib}$ $\$ 1.25$, postpaid. By express, oz. 10c; $1 / 41 \mathrm{~b}$. $30 \mathrm{c}$; 1b. $\$ 1.10$. 


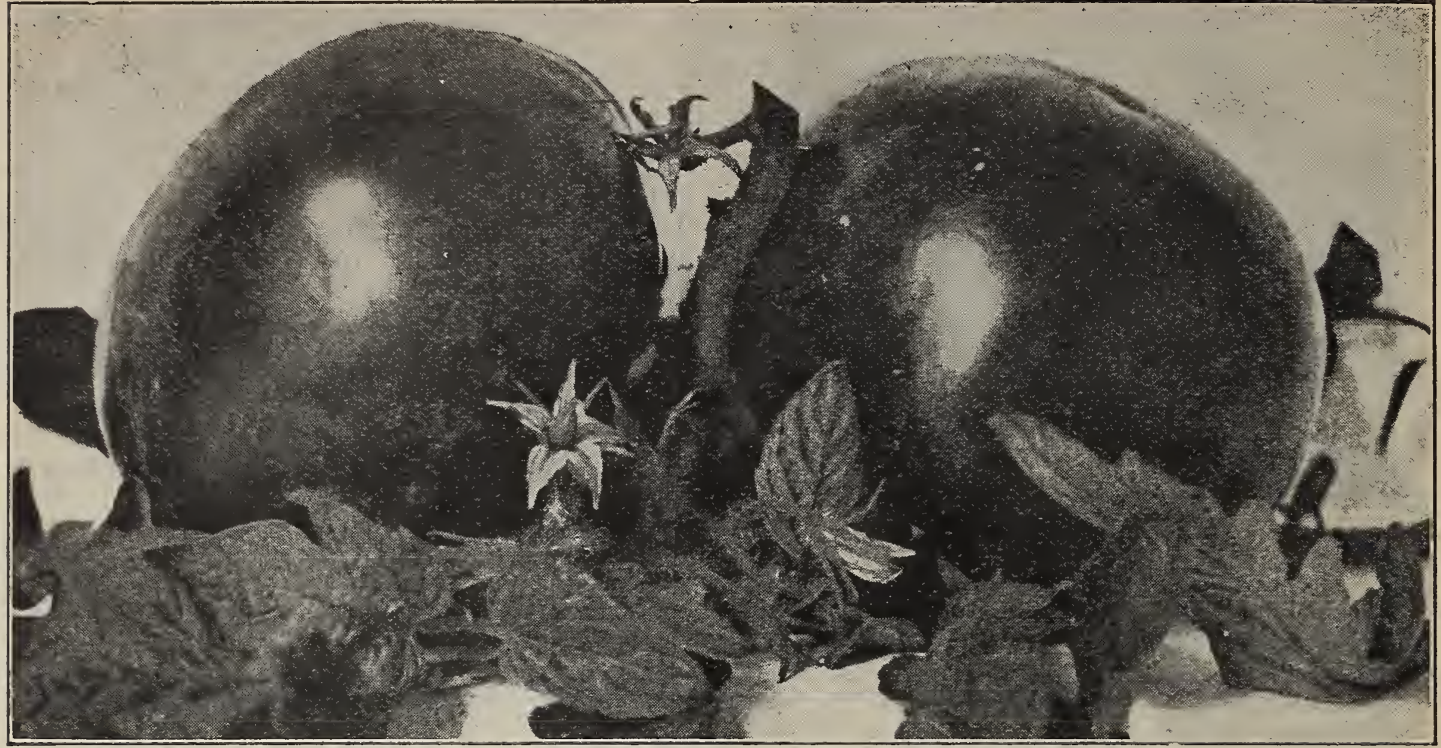

John Baer Tomato.

\section{Tomato}

CUITURE.-Sow in hot-beds or shallow boxes in the house early in the spring, transplanting in the beds to promote root growth, and when danger of Prost is over, set 3 to 4 feet apart outside. Expose to the air as much as possible to harden them, and water freely when transplanting, shading them in a few days from the sun until thoroughly established. Earliness may be promoted by growing in pots, shifting to larger size as they become filled with roots. Earlier fruits may also be had by allowing only the original stem to bear. If the plants are staked, they may be grown closer together and produce more perfect fruits.

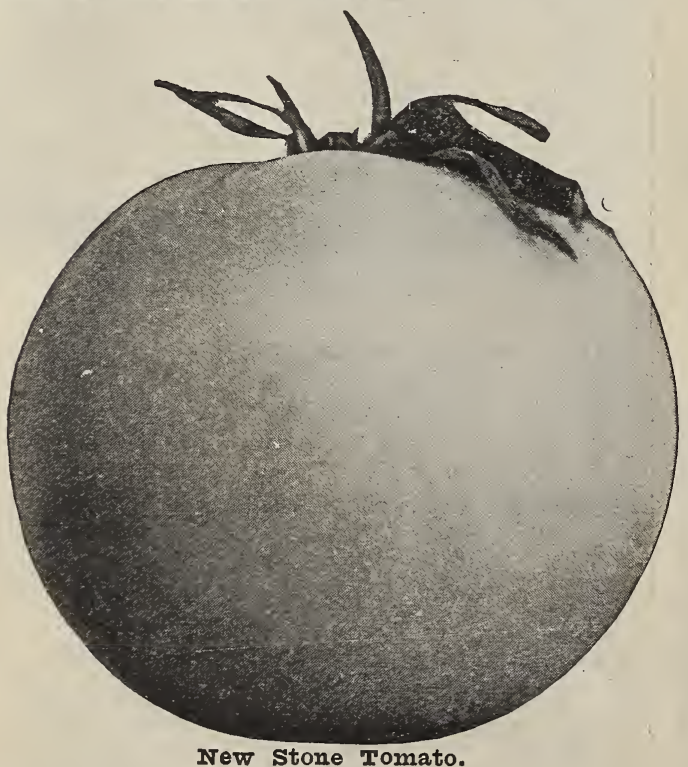

FARIANA (Special Strain)-A standard extraearly variety. Largely grown by market gardeners. Bright red, smooth and attractive in appearance. Plkt. 10c; oz. 40c; $1 / 4 \mathrm{lb}$. $\$ 1.00$, postpaid. Irot postpaid, oz. 25c; $1 / 4 \mathrm{lb} .75 \mathrm{c}$; 1b. $\$ 2.75$.

JUNR PINK-Considered an improvenient on Earliana. Extra early with beautiful pink color. Medium size, smooth and prolific. Pkt. 10c; oz, $40 \mathrm{c} ; 1 / 4 \mathrm{lb}$. $\$ 1.00$, postpaid. Not postpaid, 0z. $25 \mathrm{c}$; $1 / 4$ Ib. 80c; 1b. $\$ 3.00$.
JOHN BAER-An extra-early, large and smooth, solid, bright red Tomato. This is the earliest large, solid Tomato grown, and has proven a must profitable early market variety. Pkt. $10 \mathrm{c}$; oz. $40 \mathrm{c}$ $1 / 4$ 1b. $\$ 1.00$, postpaid. Not postpaid, oz. 30c; $1 / 4$ ib. $85 \mathrm{c}$; $1 \mathrm{~b}$. $\$ 3.25$.

FARIY ACMF-Medium early and will continue to bear until frost. One of the oldest varieties in cultivation, but one of the best. Purple in color; almost round. Smooth, solid and of good flavor. Never failing favorite. Pkt. $10 \mathrm{c}$; oz. 30c; $1 / 4 \mathrm{lb}$. $90 \mathrm{c}$, postpaid. Not postpaid, oz. $25 \mathrm{c} ; 1 / 41 \mathrm{~b} .75 \mathrm{c}$; lb. $\$ 2.75$.

BONNIF BEST-Early, smooth, bight red tomato. Medium in size. Uniform and attractive. Growing in favor for market and home use. Pkt. 10c; oz. $40 \mathrm{c}$; $1 / 4$ 1b. $\$ 1.00$, postpaid. Not postpaid, oz. $30 \mathrm{c}$; $1 / 4$ Ib. $85 \mathrm{c}$; 1b. $\$ 3.25$.

NEW STONE-Considered the best tomato for n:ain and late crop. Large, solid, bright scarlet. Very firm, uniform and hardy. Pkt. 10c; oz. 25c; 1/4 1b. $75 \mathrm{c}$; 1b. $\$ 2.50$, postpaid. Not postpaid, oz. $25 \mathrm{c}$; $1 / 4$ 1b. 60c; 1b. $\$ 2.00$.

MATCHIESS-One of the best main crop tomatoes. Very solid; few seed; large smooth fruit. As a main crop, it is unsurpassed. Pkt. $10 \mathrm{c}$; oz. 35c; $1 / 4$ 1b. 90c; 1b. $\$ 3.25$, postpaid. Not postipaid, oz $25 \mathrm{c} ; 1 / 4$ lb. $80 \mathrm{c}$; 1b. $\$ 3.00$.

NORTON WIIT RESISTING-This is similar in shape, size and color to the well-known Stone, but resists blight better than any other variety. It is very hardy. Pkt. 10c; oz. 40c; 1/4 1b. \$1.25; is. $\$ 4.60$, postpaid. Not postpaid, $1 \mathrm{~b}$. $\$ 4.50$.

PONDFROSA-An extra large and very handsome, bright red tomato. Flesh. thick, solid and of fine quality. Especially recommended for home gardeners. Pkt. 10c; oz. 50c; 1/4 1b. \$1.50, postpaid. Not postpaid, oz. $40 \mathrm{c}$; $1 / 4$ 1b. $\$ 1.25$; 1b. $\$ 4.50$.

BRIMMTR TOMATO-A large variety, of fine quality, very solid, productive, and practically all meat, containing very few seeds. A splendid variety for home gardens. Pkt. 10c; 1/2 oz. 50c, postpaid.

GOLDFN PONDFROSA-One of the largest of the yellow tomatoes; very handsome, solid and smooth: very productive. Plst. 10c; oz. 50c; 1/4 1b. \$1.50, postpaid. Not postpaid, oz. 40c; $1 / 4 \mathrm{lb}$. $\$ 1.25$.

YFIIOW PFAR-Small pear shaped variety, used for preserving. Pkt. 10c; oz. 40c, postpaid. Not postpaid, oz. $35 \mathrm{c}$. 


\section{Turnip and Ruta Baga}

CUITURE-Spring sowing should be put in early so that they will attain a good size before hot weather, otherwise they will become tough and bitter. For the regular crop, sow the early sorts in July or August, the later sorts during August, and the salad varieties during August and September. Sow either broadcast or in drills 2 feet apart, thinning out to 6 inches, and roll the ground after sowing. Rutabagas should be sown in July and early in August, and earthed $u p$ as they grow. Sow 11/2 pounds to the acre in drills, 2 pounds broadcast; salad turnips 3 pounds to the acre.

FARTY FIAT DUTCF-An extra early pure white flat growing variety. Recommended for early market. Oz. 10c; 1/4 1b. 20c; 1b. 65c, postpaic. By express, oz. 5c; $1 / 4$ 1b. $15 \mathrm{c}$; $1 \mathrm{~b}$. $60 \mathrm{c}$.

EARIY PURPIE TOP STRAPIEAF-Flat, white with purple top. Fine grained and tender. Used for early market and table. Oz. 10c; 1/4 1b. 20c; 1b. $40 \mathrm{c}$, postpaid. $\mathbf{B y}$ express, oz. $5 \mathrm{c}$; $1 / 4$ 1b. $15 \mathrm{c}$; 1b. 50c.

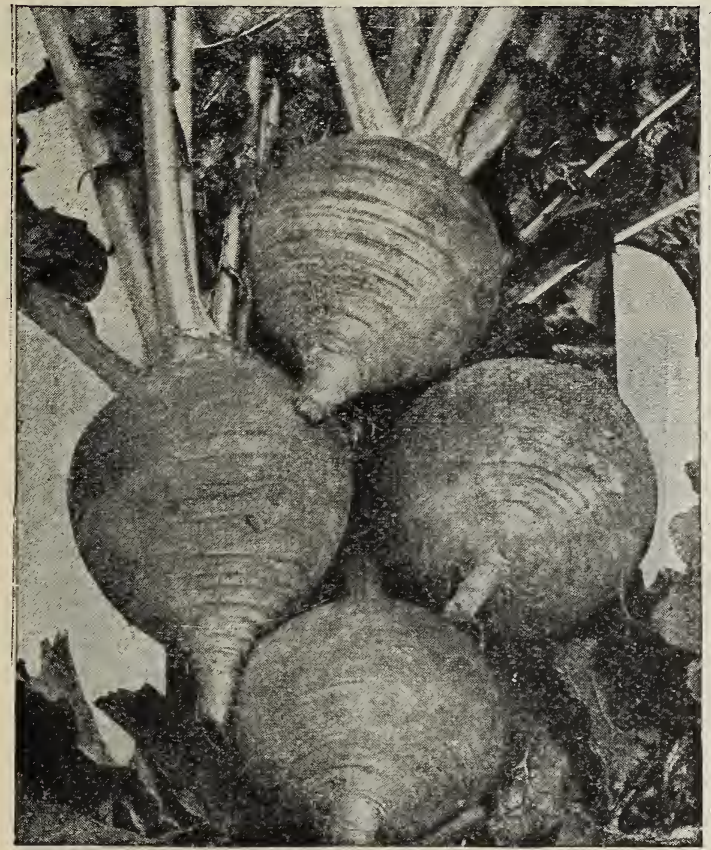

Iarge Yellow or Amber Globe.

IAIGE WrITE NORFOTK GIOBE-Makes large, round, handsome, white roots, excellent for table and stock. Oz. 10c; 1/4 1b. 20c; 1b. 50c, postpaid. By express, oz. 10c; $1 / 4$ ib. $15 \mathrm{c} ; 1 \mathrm{~b} .40 \mathrm{c}$.

IMPROVED AMTERICAN PURPLE TOP WHITE GTOBE-The most popular turnip for market ane? table use. Makes large, globe shaped roots, pure white, with purple top. A heavy yielder and unsurpassed in quality. Oz. 10c; 1/4 1b. 25c; 1b. 60c, postpaid. By express, oz. 10c; $1 / 4$ 1b. 20c; 1b. 50c.

IONG WHITE COW FORI-A very attractive quick growing turnip. Used especially for stock feeding. Oz. 10c; $1 / 4$ Ib. 25c; 1b. 75c, postpaid. By express, oz. $10 \mathrm{c} ; 1 / 4$ 1b. 20c; 1b. $70 \mathrm{c}$.

IARGE YEITOW, or AMBER GIOBE-Of large size, globe shaped, solid yellow flesh, green tor. Fine for table and stock. Keeps firm and sweet throughout the winter. Oz. 10c; 1/4 1b. 20c; $1 \mathrm{~b}$. $50 \mathrm{c}$, postpaid. By express, oz. $10 \mathrm{c}$; $1 / 4$ 1b. $15 \mathrm{c}$; 1b. $40 \mathrm{c}$.

XFIIOW ABERDFEN, PURPIE TOP-A splendid keeping variety with firm, solid yellow meat. Keeps throughout the winter, and especially recommended for stock feeding. Oz. 10c; $1 / 41 \mathrm{~b}$. 20c; 1b. 50c, postpaid. By express, oz. 10c; $1 / 4$ 1b. 15c; 1b. $40 \mathrm{c}$.

WHITF FGG-A quick growing, egg shaped, pure white variety. Very sweet, firm, and mild. Oz. 10c; $1 / 4$ 1b. 20c; 1b. 60c, postpaid. By express, 07. $10 \mathrm{c} ; 1 / 4$ 1b. $20 \mathrm{c}$; 1b. $50 \mathrm{c}$.

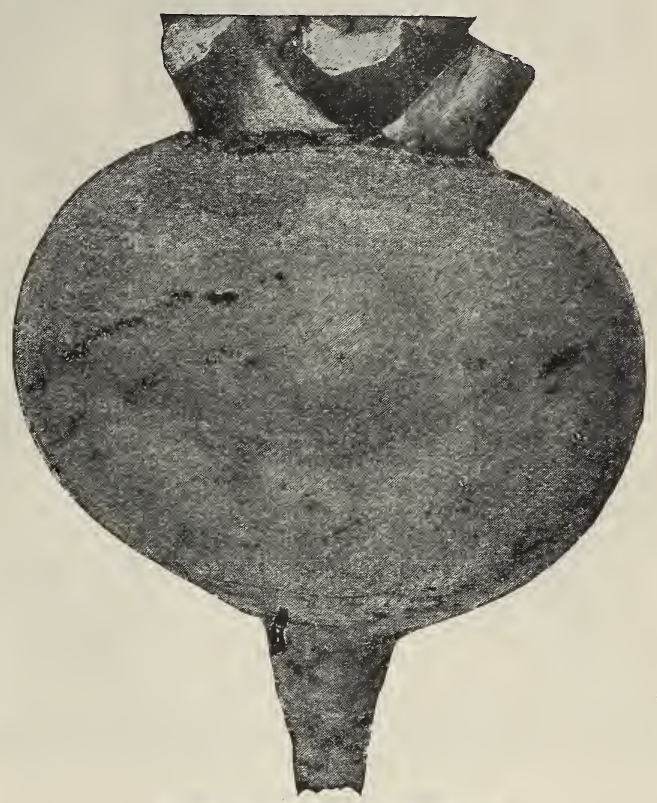

Iarge White Norfolk Globe.

IMPROVED AMERICAN PURPTE TOP RUTABAGA -An improved strain of the finest yellow fleshed rutabaga grown. Hardy, sweet and is a good keeper. Oz. 10c; $1 / 4$ 1b. 20c; 1b. 60c, postpaid. By express, oz. 10c; $1 / 4$ 1b. 15c; 1b. $50 \mathrm{c}$.

\section{SAIAD VARIFIIES}

SOUTHFRN PRIZF, or DIXIF-Considered the best salad variety known. Very hardy, withstands cold, and makes beautiful luxuriant salad. Oz. 10c: $1 / 4$ 1b. 30c; 1b. $\$ 1.00$, postpaid. By express, oz. 10c; $1 / 4$ 1b. 25c; 1b. $90 \mathrm{c}$.

SFVFN TOP-The old standard popular salad variety, grown exclusively for this purpose. Oz. 10c; $1 / 4$ 1b. 30c; 1b. $\$ 1.00$, postpaid. By express, oz. $10 \mathrm{c} ; 1 / 41 \mathrm{~b} .25 \mathrm{c}$; $1 \mathrm{~b}$. $90 \mathrm{c}$.

\section{Herbs}

IAVENDER-Pkt. 5c; oz. 25c SWFFT IMARJORATI-Pkt. 5c; oz. 300. SAGE-Pkt. $5 \mathrm{c}$; Oz. $15 \mathrm{c}$. THXIMF-Pkt. $5 \mathrm{c}$; oz. $50 \mathrm{c}$. SAVOY-Pkt. $5 \mathrm{c}$; oz. $15 \mathrm{c}$. CARAWAY-Pkt. 5c; oz. $20 \mathrm{c}$.

DIII-Pkt. 5c; oz. 20c.

All Vegetable Seeds offered in this Catalogue are New Crop, 1924 growth, and produced by the most careful growers in the country. We cannot improve in quality. We try to please our customers in prices.

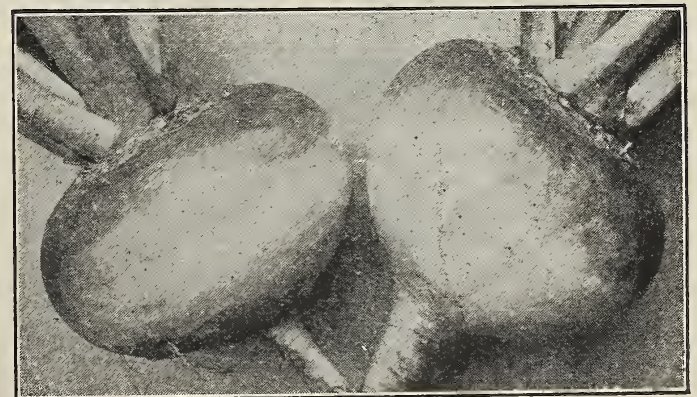

American Purple Top Globe. 


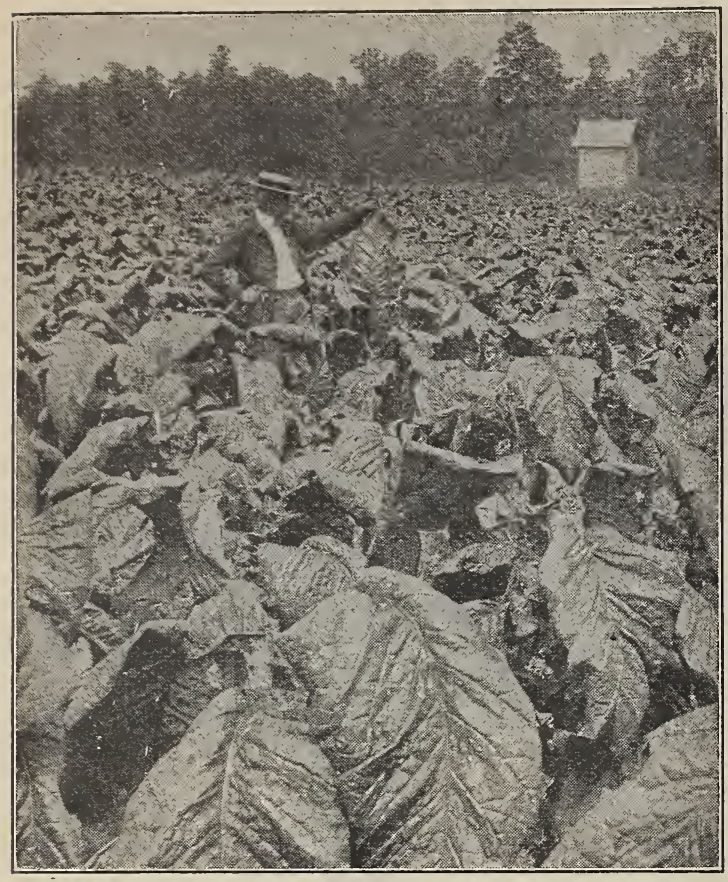

Gold Iea: Tobacco.

\section{Tobacco Seed}

One Ounce Will Sow Fifty Square Yards.

Our Tobacco Seed are grown in the Virginia tobacco belt by a reliable tobacco grower, who makes a specialty of growing seed, true to name and recleaned of all filth and imperfect seeds.

CUITURE-Sow in February and March in a rich and perfectly clean bed from which all seeds and insects have been destroyed by firing. Protect from flies, and transplant about June $3 \frac{1 / 2}{2}$ to 4 feet each way. During growing season guard against suckers and worms.

\section{BRIGHT VARIETIES}

IMPROVID GOIDEN ORONOKO-A select strain of this standard variety. Very popular and extensively grown; large, erect growth, with large leaves of finest texture. Price, oz. $30 \mathrm{c} ; 1 / 4 \mathrm{lb}$. $75 \mathrm{c}$; 1b. \$2.75, postpaid.

IMPROVID FIESTER-For wrappers, cutters, fillers, or cigars, fairly long, of medium width, cures bright. Best adapted to gray or sandy soils overlying yellow clay or chocolate soils. $\mathrm{Oz} \mathrm{30 \textrm {c }}$ $1 / 4$ 1b. $75 \mathrm{c}$; 1b. $\$ 2.75$, postpaid.

WARNE-For bright wrappers, this variety is unexcelled; grows to large size, and holds up well. Leaf is large, of medium breadth and very fine grain. Price, oz. 30c; $1 / 4$ 1b. $75 \mathrm{c} ; 1 \mathrm{~b}$. $\$ 2.75$, post. paid.

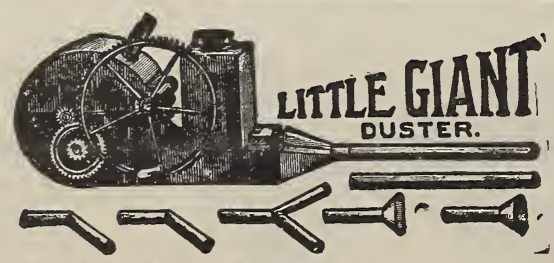

IITTIE GIANT DUSTER-Distributes any dry powder, like Dry Arsenate of Lead, Slug Shot and Paris Green, to perfection. Keeps the poison at a safe distance from the operator, and will dust potato plants as fast as the operator can walk, two rows at a time. One of the best appliances for tobacco growers. By turning a handle a fan is rapidly revolved, distributing the insecticides uniformly on two rows at once, and to all parts of the plant and on both sides of the leaf. Price, $\$ 11.00$.
GOID IFAF-Considered the finest of all bright varieties. Leaf long and broad, producing a combination of weight and quality unequalled. Price, oz. $40 \mathrm{c} ; 1 / 4 \mathrm{lb}$. $\$ 1.00$, postpaid.

ADCOCK-An old popular variety. Considered one of the best for growing on poor land. Long, broad leaf of good texture. Price, oz. $30 \mathrm{c}$; $1 / 4$ 1b. $85 \mathrm{c}$; 1b. \$2.75, postpaid.

\section{DARK VARIFTIES}

BIG ORONOKO-The largest and heaviest variety of the Oronoko strain, and a sure winner for dark wrappers. Has large broad leaf of handsome appearance; cures well, and possesses weight and body. Price, oz. 30c; $1 / 4 \mathrm{lb}$. 80c, postpaid.

KENTUCKY YEIIOW-A fine, large, broad-leaved tobacco for strips, dark wrappers and fillers. Best suited to chocolate alluvial and rich red clay soils, producing heavy crops. Price, oz. 30c; $1 / 4$ 1b. $75 \mathrm{c} ; 1 \mathrm{~b}$. $\$ 2.75$, postpaid.

BIUE PRYOR-A large, long and broad leaf. Makes a rich, waxy tobacco for black wrappers, strips, and fillers, and a rich export tobacco; best adapted for rich alluvial soils. Price, oz. $30 \mathrm{c}$; $1 / 4 \mathrm{lb}$. $75 \mathrm{c}$; 1b. $\$ 2.75$, postpaid.

ONE SUCKER-A dark manufacturing sort of good breadth, long leaf, and rich quality. Best suited to alluvial, chocolate and. rich red clay soils Price, oz. $30 \mathrm{c} ; 1 / 4 \mathrm{lb}$. $75 \mathrm{c}$; $1 \mathrm{~b}$. $\$ 2.75$, postpaid.

\section{Cotton Seed}

The Cotton Seeds offered by us are early types, especially adapted for Virginia. Our seed is grown in Virginia from the best crops, and great care has been taken by us to keep each variety true to name and free from mixture.

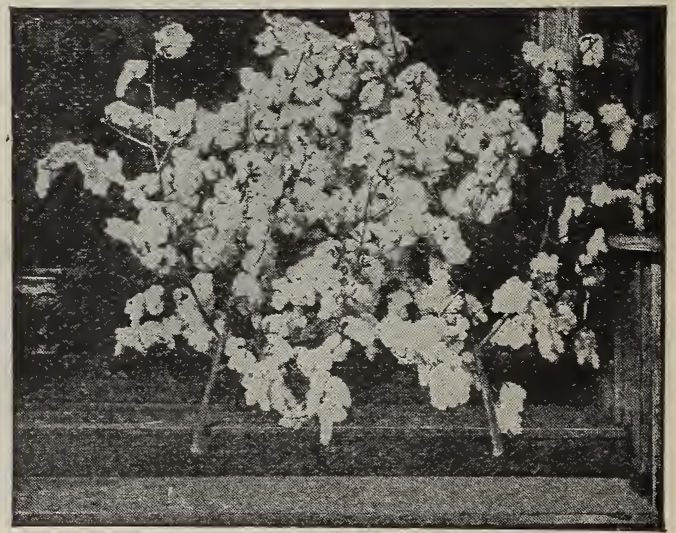

Cleveland Big Boll Cotton.

IMPROVED EARIY IRING COTTON-This splendid variety will make its crop early and will open uniformly, and is especially recommended for the northern part of the cotton belt. Wherever the Improved Jing variety was planted in this section, the results were very satisfactory. Per bu. of 30 lbs. \$2.25; 5-bu. lots and over, $\$ 2.00$ per bu. CIEVIIAND BIG BOII-A hardy, drought-resisting cotton that opens early enough in Virginia to escape boll weevil. Results with this variety have made it a favorite in this section. Staple is about an inch long and will average about 40 per cent lint. Price, per bu. of 30 lbs. \$2.25; 5 bu. lots and over, $\$ 2.00$ per bu.

We will have in stock the seeds of several splendid crops of 1924, grown in this section, of which the growers do not know the name. They opened up uniformly to the entire satisfaction of the growers. Price on these lots, $\$ 1.75$ per bu.

\section{PIANT BID CANVAS}

We carry two grades of Plant Bed Canvas.

Our No. 100 is a medium quality and considered suitable by most of our tobacco growers. Sold in pieces of 70,71 and 74 yards each. Price, 4c per yard, parcel post prepaid.

Our No. 400 is a closer woven canvas and well worth the difference in price. Sold in pieces of about 65 to 70 yards each. Price, $41 / 2 \mathrm{c}$ per Jard, parcel post prepaid. 


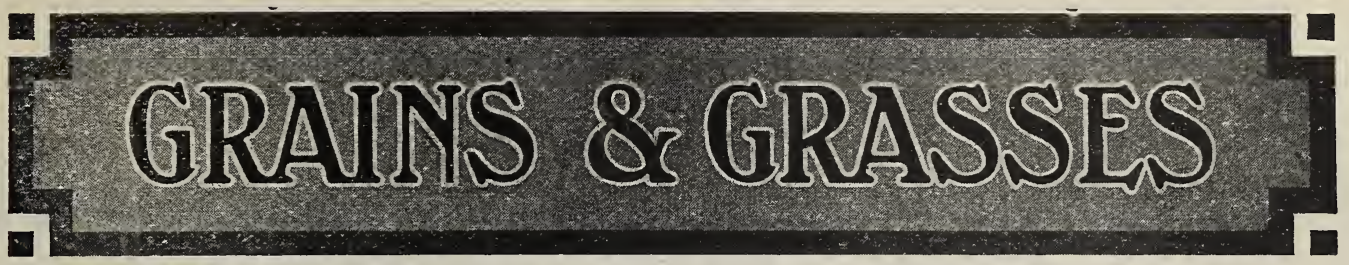

THE SEEDING OF GRASS AND CLOVERS

To begin with, let us bear in mind that land requires as much careful preparation and attention for the seeding of these field crops, as it does for the smallest vegetable seeds, and that we cannot expect to harvest two or three tons of hay per acre on land that has not had the proper treatment and nourishment. We shuld get out of the old habit of making up our mind at the last moment to put this or that piece of land in grass or clover, because, as a rule, this or that land is not in proper condition for seeding; we should try to look and plan ahead from year to year, so our land may be ready and in such physical condition as to insure good returns for what we have done for it.

\section{PREPARATION OF IAND}

Begin the preparation of land by feeding 1 t, viz.: Adding humus through green fallow crops, such as cowpeas, crimson clover, vetch, etc.; any of these crops will more than pay for themselves in either cured or green feed, and the stubble turned under will enrich the soil in nitrogen and humus, as these plants obtain their supply of nitogen from the air and give it to the soil. Should the land be thin, an application of three to four hundred pounds of acid phosphate per acre will help to give these crops sufficient growth for the purposes desired.

Having supplied the land with food in the form of humus, we should give it a sweetener-Limean application of 1,000 to 2,000 pounds per acre, according to the character of the soil, will aid the land to digest the food given it, and will render available for the use of the grass and clover plants, the various plant foods contained in the soil. This application of lime should be turned under with the green fallow, or when land is disked preparatory to seeding. A further application of 400 to 500 pounds of Pure Raw Bone Meal per acre at seeding time will increase the yield of hay and give longer life to the plants.

\section{PIOWING, DISKING AND SEEDING}

In the seeding of grass and clovers, a firm, wellprepared seed bed is a most important factor, and to obtain this the land should be deeply fallowed and allowed to remain so for at least two weeks before touching further. This allows the ground to settle, weed seeds to sprout (which are afterwards killed by disking), and the air to penetrate the soil thoroughly; after this has been accomplished, disk the land thoroughly until the surface is in first class condition; then sow the seed carefully, preferably with a Cahoon Seeder, and cover lightly to a depth of about one-half inch; then run the roller over the whole, unless the land is too wet or inclined to bake.

\section{TIME OF SFFDING}

Grass and clovers can be seeded in Spring, in February, March and April. or in Fall, during the months of September and October. In Fall seeding it is customary to sow either oats, wheat or rye with it, which method affords two crops on same land, the grain crop being harvested in early summer, and a cutting of hay being made later in the season. However, it is our belief that better results are obtained by seeding without grain, as generally the grain crop is removed from land during a hot dry spell, and the grass plants, tender from being shaded by the grain, are more or less damaged and killed by the hot sun, the result often being a poor stand, and consequently a short hay crop. A point in favor of the grain addition, however, is the protection the same affords the young grass during the winter.

\section{PRICES IIUCTUATI}

Prices on all Field Seeds are constantly fluctuating. and are subject to change without notice. We will glady quote lowest current price at any time on application. Prices in this catalogue are prevailing January 1,1925 , and are based on seeds of highest quality in germination and purity.

\section{NOTICE}

Prices quoted in this catalogue on all grasses, clovers, and other field seeds, are f. o. b. Petersburg. If ordered to be sent by mail, refer to "Parcel Post Table" on page 2, and add to remittance accordingly. Cotton bages are charged extra at cost also. Add $45 \mathrm{c}$ for a $21 / 2$-bushel cotton bag. $25 \mathrm{c}$ for a one-bushel bag, and $15 \mathrm{c}$ for smaller size bags in ordering such seeds as require a seamless cotton bag to insure safe arrival.

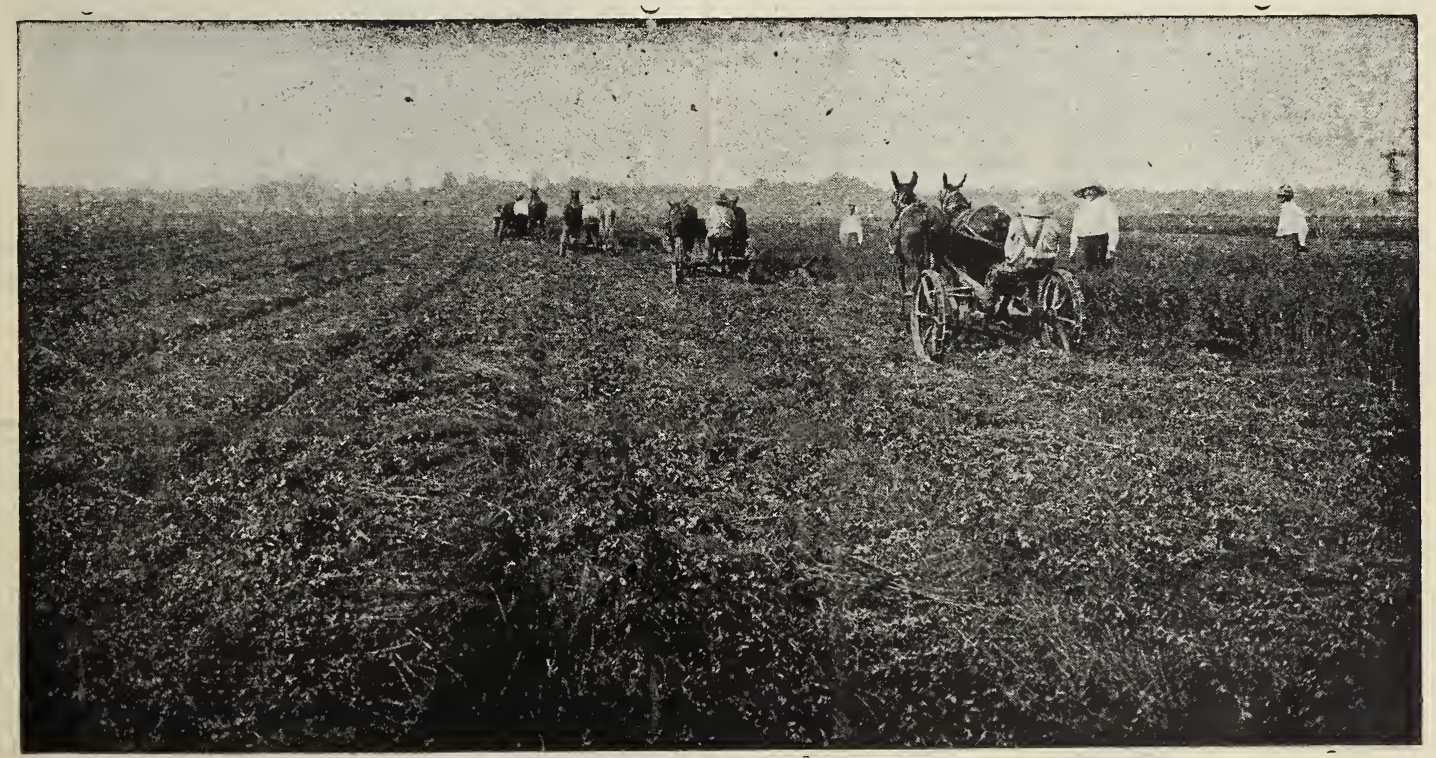




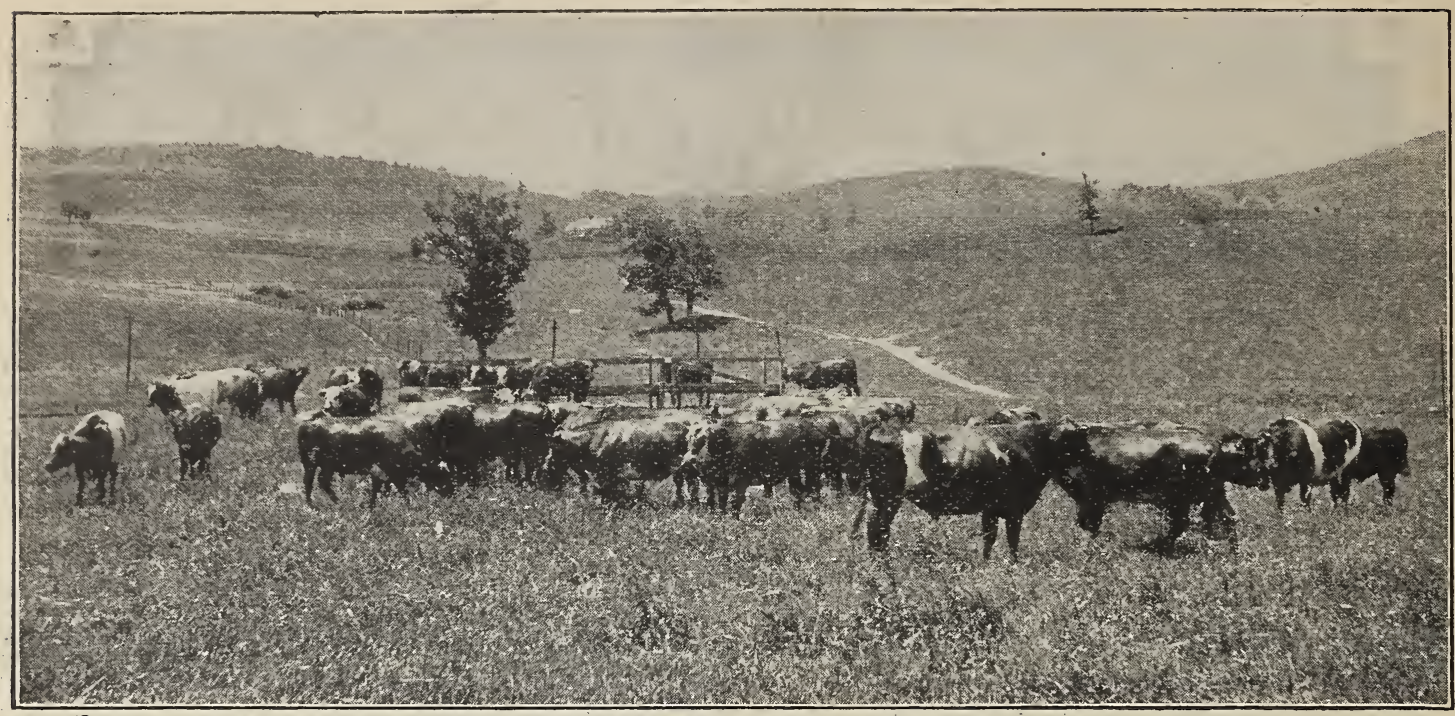

\section{Clover and Grass Seed Mixtures}

Experience has taught us that certain mixtures of grasses and clovers will give us better results, netter satisfaction, and better returns than the seering of one variety of grass or clover by itself. This is due to the fact that where a mixture is used, we are more apt to get a good stand, as, even though one or two varieties of seed in the mixture should fail to germinate, there still remains enough of the other varieties to cover the ground; whereas, if one variety is used, and the seed failed to germinate, our time and labor would be entirely lost, and we would have to do the whole work over again.

Different mixtures of seeds in different proportions are necessary for various soils, and care should be taken in seeding mixtures, to combine only such varieties as are adapted to the same soil, and will mature practically at the same time.

Through practical experience, we recommend for PERMANENT HAY on high lands, the following: A mixture of Orchard Grass, Meadow Fescue, Alsylke Clover, Red Clover, and a sprinkling of Alfalfa. The cost of this mixture in proper proportions, based on today's prices, would be $\$ 6.00$ per acre, seeded at the rate of $25 \mathrm{lbs}$. to each acre. We quote this mixture in smaller quantities at $28 \mathrm{c}$ per $1 \mathrm{~b}$.

This mixture, with the addition of five pounds of Red Top or Herds Grass per acre, will also make a fine PERMANENT PASTURE for High Land.

For a mixture suitable for PERMANENT HAY in Low Lands, good rich bottoms, we recommend the following grasses and clovers in proper proportions: Timothy, Meadow Fescue, Sapling Clover, Herds

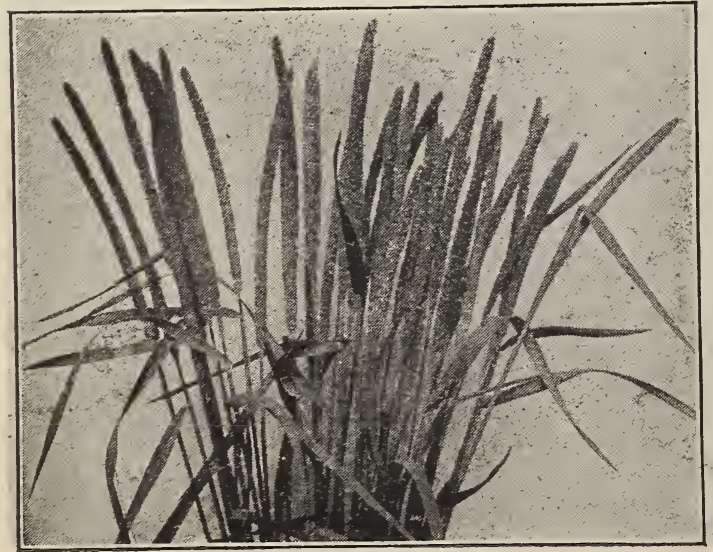

Timothy.
Grass, and Alsyke Clover. This mixture will cost on today's market $\$ 5.50$ per acre; 25 lbs. per acre. Price of this mixture in smaller quantities would be $27 \mathrm{c}$ per $1 \mathrm{~b}$.

A good mixture for PERMANENT PASTURE for moist bottom lands is a combination of the following grasses and clovers: Italian Rye Grass, Red Top Grass, Tall Meadow Oat Grass, Alsyke Clover and Timothy. Cost per acre, $\$ 5.00 ; 25$ lbs. per acre. Price of this mixture in small lots, 25c per 10.

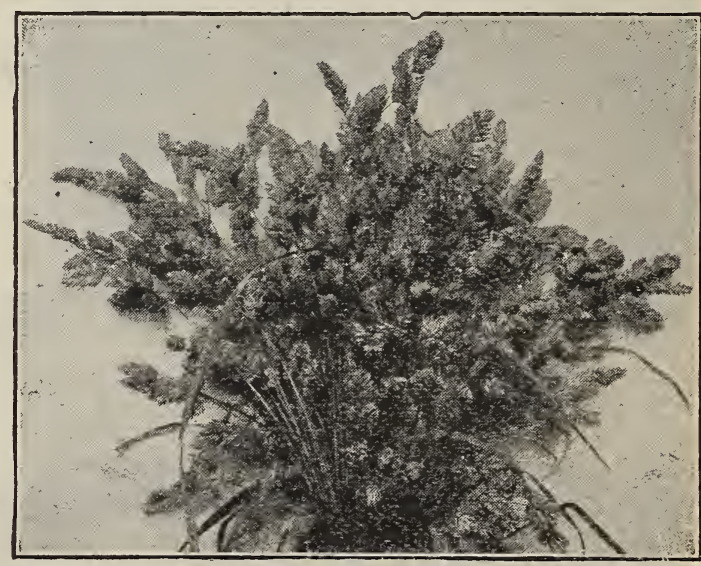

Orchard Grass.

\section{GRASSES}

TIMOTIY-This is considered the most nutritious and salable of all hay grasses. Best adapted to clay or heavy loam, rich low lands or bottonis, as well as mountainous districts. Timothy does not root as deeply as other grasses, and should not be sown on lands deficient in humus, nor on light and sandy soil. In this section Timothy is lafgely sown with Sapling Clover, Herds Grass and Meadow Fescue, which combination on suitable soil wiłl make a large yield of excellent hay and afford good pasturage. Sow this mixture at the rate of eight pounds Timothy, five pounds Clover, five pounds Herds Grass, one-half bushel Meadow Fescue Grass per acre. If sown alone, use twelve to fifteen pounds Timothy per acre. Timothy, alone or in a mixture, can be sown in Fall or Spring. Price, per 1b. 15c; bushel, $\$ 4.25$, 
ORCHARD GRASS-This is one of the most reliable grasses for hay or pasture, making a quick and vigorous growth, yielding large crops of excellent and nutritious hay, and lasting for years with increasing value if properly taken care of. Maturing early, it generally yields two crops of hay ing early, it generally yields two crops of hay most all soils, but does best on loamy uplands or moderately stiff soil. It gives best results when sown with Tall Meadow Oat Grass and Red Clover. If sown alone for hay, use two bushels per grass, one bushel Tall Meadow Oat Grass, and eight pounds of Red Clover per acre. If sown for pasturage, use one bushel Orchard Grass, one-half bushel Meadow Fescue, four pounds recleaned Herds Grass, three pounds Alsike Clover per acre. Price, per 1b. 25c; bushel $\$ 3.00$.

TAII MIEADOW OAT GRASS-This is a very valuable and popular grass for the South, as it withstands heat and drought well, and succeeds better than any other grass on light, medium and sandy soil. It ripens at the same time as Orchard Grass, and the best results are obtained by sowing with Orchard Grass and Red Clover at the rate of one bushel Tall Meadow Oat Grass, one bushel Orchard Grass, eight pounds Red Clover. If it is desired to make a pasture after first cutting, add to the above mixture five pounds recleaned Herds Grass Seed. If sown alone, use from two to three bushels Tall Meadow Oat Grass per acre. Price, per 1b. 25c; bushel \$2.75.

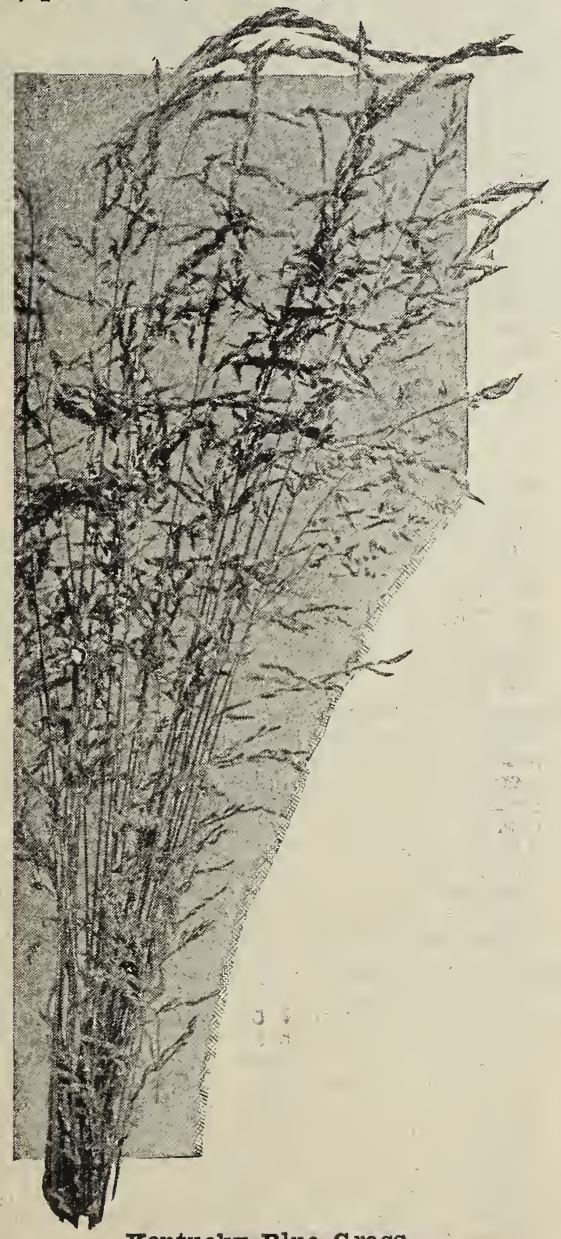

Kentucky Blue Grass.

PERENNIAI RYE GRASS-A quick growing, early maturing grass, furnishing good grazing early in the season. Can also be used for hay, in a mixture of one bushel Orchard Grass, one bushel Tall Meadow Oat Grass, and one bushel Perennial Rye Grass. Can be sown in Fall or Spring. Pice, Grass. Can be sown in Fall or Spring. Pulice, per po

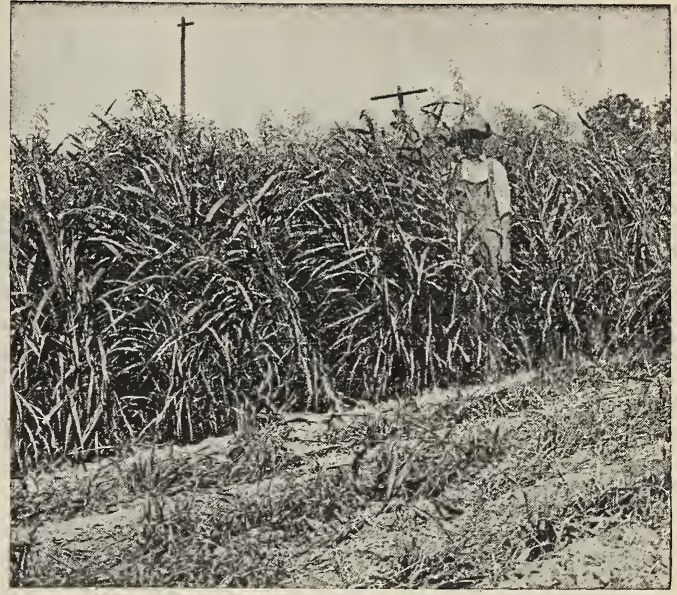

Sudan Grass.

KENTUCKY BIUE GRASS-This is the richest and most nutritious of all pasturage grasses, and should be largely used in pasture mixtures except on light and sandy soils. Blue Grass is best adapted to soil with limestone foundation, but can be made to grow if proper fertilizing and liming is given. A mixture of two bushels Blue Grass and eight pounds recleaned Herds Grass per acre on fertile soil, with red clay subsoil, will give an excellent pasture. Can be sown in the Fall

SUDAN GRASS-A sweet, heavy yielding annual grass, yielding from three to four cuttings of good hay. Very thick growing and withstands drought exceptionally well. Recommended for a quick Summer hay crop, or green food during the Summer months. Should be sown when the ground and weather becomes warm in the Spring, either in drills two feet apart at the rate of about ten pounds per acre, or broadcasted at the rate of 25 to 30 pounds per acre. On account of its rapid and luxuriant growth, Sudan Gass is trying on the soil, and should not be sown on thin land. Price, per pound of certified Sudan Grass seed, free of per 1b.; 100-1b. lots, 10c per 1b.

ITAIIAN RYE GRASS-Recommended principally for. Fall seeding. Will yield two to three cuttings of nutritious hay per year, and particularly adapted for rich, loamy soils and low grounds.

BERMIUDA GRASS-This grass is very valuable in the South for grazing, as it makes a very vigorous, persistent growth, and lasts for years. In Virginia, it is used mainly for golf courses, athletic grounds, and on land liable to wash; on galled places, railroad embankments, mill dams, etc. Per 1b. 55c; in 10-1b. lots, $50 \mathrm{c}$ per $1 \mathrm{~b}$; ; in 100-1b. 10tg, 48c per $1 \mathrm{~b}$.

RED TOP, or HERDS GRASS-This is undoubtedly one of the most satisfactory grasses throughout the South. It is adapted to all soils, succeeding well on light, sandy soils, as well as stiff uplands and low grounds, on dry hillsides as well as wet bottoms. Being once established, it thickens and improves each year, making it exceptionally valuable as a permanent pasture. As a hay crop, it should be sown with Timothy and Sapling Clover at the rate of five pounds Herds Grass, elght pounds Timothy, four pounds Sapling Clover per acre. As a permanent pasture, it should be sown in a mixture of six pounds Herds, eight pounds Timothy, four pounds Alsike Clover, one-half bushel Orchard Grass per acre. This mixture can also be cut for Hay, and then be turned into pasture. If sown alone, Herds Grass should be sown at the rate of eight to ten pounds per acre. Can be sown either in Fall or Spring. Price, Fancy recleaned Herds Grass, per 1b. 20c; per $100 \mathrm{lbs}$. $\$ 17.00$.

Timothy, Red Top Grass and Clover Seeds require seamless cotton bags for safe transportation. Bags extra at cost, 2 bu. bags, $45 \mathrm{c}$; 1 bu. bag 25c; 15 lb. bags, 150 each. 


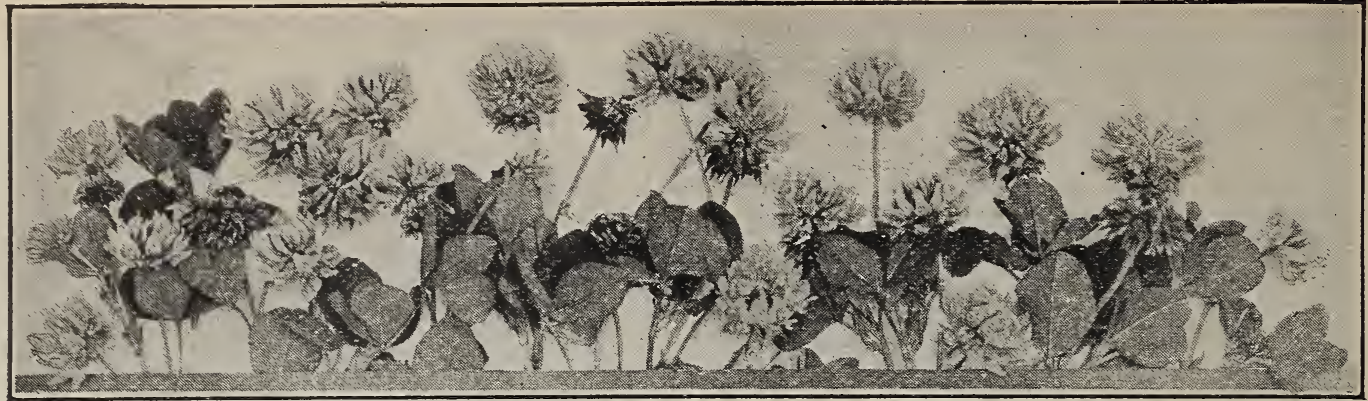

Rea Clover.

MEADOW rHSCUF-This splendid grass is gaining in popularity throughout Virginia and the South, succeeding well in early all sections. It is a splendid Spring and Summer grass, and very useful for Fall and Winter pasturage, remaining green throughout the Winter. It is especiaily recommended in mixtures in the following proportlons: For Fay-One bushel Meadow Fescue, ive pounds Herds Grass, six pounds Timothy per acre. For Permanent Pasture-One bushel Meadow Fescue, four pounds Herds Grass, five pounds Timothy, one-half bushel Orchard Grass, one-half bushel Tall Meadow Oat Grass, three pounds AIsike Clover per acre. If sown alone, use two bushels per acre. Sow in Spring or Fall. Price, per 1b. 20c; bushel $\$ 2.50$.

\section{Clovers}

RED CLOVFR-This is the old standby of all clovers, and is more largely used than any other, for hay, pasturage, and improvement of the soil. Sow either in Fall or Spring, alone or in mixtures, and yields from one to three cuttings per year. In this section, it is largely sown in February and March on Fall sown grains, by running a harrow over the grains, sowing the clover and following with a pea weeder or harrow cross-wise. This not only puts the seed in properly, but gives the grain a much needed cultivation. Red clover gives best results as a hay crop when used in the following mixture: Eight pounds clover, one bushel Orchard Grass, one bushel Tall Meadow Oat Grass per acre. If it is desired to turn the field into pasturage after cutting, add to the above mixture six pounds of Herds Grass Seed. If sown alone, use 10 to 12 pounds of Red Clover Seed per acre. Price, per 1b. $40 \mathrm{c}$; bushel, $\$ 23.00$.

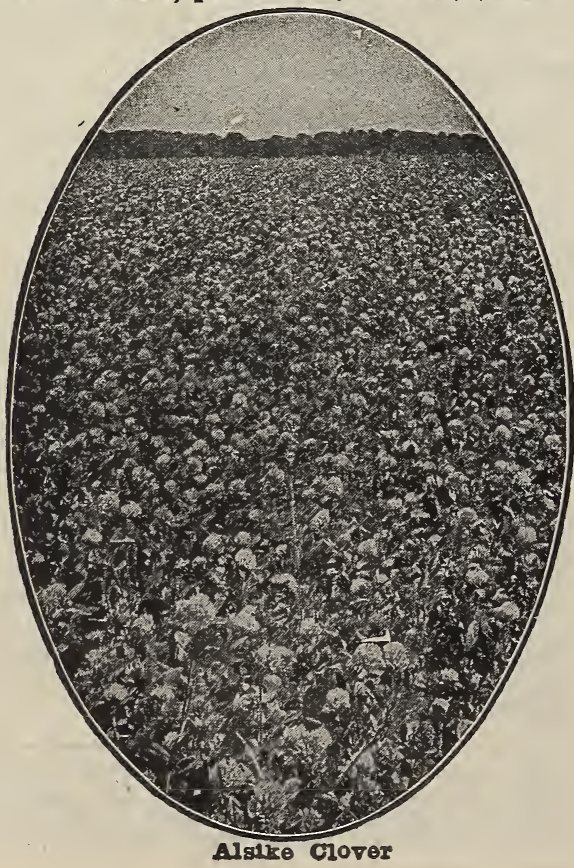

MAMEMOTH, or SAPIING CIOVIR-This clover is indentical in habits and characteristics with the Red Clover, with the exception that it usually grows larger and matures two to three weeks later. As a soil improver it is preferred to the Red Clover on account of the extra growth. Maturing at the same time as Timothy, it is at its best as a hay crop if sown at the rate of seven pounds clover and ten pounds of Timothy per acre. As a pasture mixture, add six pounds Herds Grass per acre to the above mixture. Can be sown like Red Clover, in Fall or Spring. Price, per pound Sapling Clover, 45c; per bushel, \$26.00.

AISIKF CIOVFR-This clover grows thicker than Red Clover, though not quite so tall. It is found to be hardier, resisting heat, drought, and cold weather better than other clovers. In this section, the Alsike Clover has proven to give better stands, better crops and better grazing than the Red Clover, and it is fast growing in popularity. We strongly recommend Alsike Clover in mixtures, especially for pasturage. Sown alone, 6 to 8 pounds is required per acre. As a lowland pasture mixture, use six pounds Herds Grass, four pounds Alsike, six pounds Timothy per acre. Can be sown in Spring or Fall. Price, per pound Alstke Clover, 30c; per bushel, $\$ 15.00$

WHITY BOKHARA, or SWEFT CIOVIR-This is a very valuable clover for Virginia, and should be used very largely for the redemption of worn-out soils, and on hillsides subject to wash, as it will make $a$ growth on the thinnest of soils, adding humus and body to the land and inoculating the same for other clovers and alfalfa. It makes a nutritious hay if cut young, and affords splendid pastuarge. The life of this clover is two years, but will reseed itself if allowed to go to seed the second year. Can be sown in Fall or Spring at the rate of 15 to 20 pounds per acre. Price, per pound, hulled and scarified seed, 18c; 10-1b. 1ots, $16 \mathrm{c}$ per $1 \mathrm{~b}$.

JAPAX CIOVRR-This has proven to be a very valuable crop for the South. Both as an excellent pasturage and as a soil improving crop. It will rrow on most any soil, and is especially recommended for the redemption of hillsides and barren and waste lands. Should be seeded in March or April at the rate of 10 to 15 pounds per acre. It can also be sown in connection with Herds Grass for pastuarge at the rate of ten pounds Japan Clover and eight pounds Herds Grass per acre. Price, per 1b. 30c; bushel of 25 1bs. $\$ 6.75$.

WHITE BIOOMING CRIMSON CIOVFR-Same as the red crimson clover, but has white bloom, and is later in maturity. The white bloom is more desirable for hay and forage, and when sown with rust-proof oats makes the most desirable hay. We also recommend very highly from personal experience, the seeding of rust-proof oats, white bloom crimson clover and hairy vetch, which combination yields exceedingly heavy crops of most nutritious hay. This combination should be sown at the rate of $11 / 2$ bushels rust-proof oats, $101 \mathrm{bs}$ white bloom clover, 10 lbs. hairy vetch per acre. Price, per 1b. 15c; per bu. \$7.00.

\section{NOTICE}

The Mammoth or Sapling, Ied and Alstke Clovers offered in this catalogue are genuine rorth American grown seeds. 


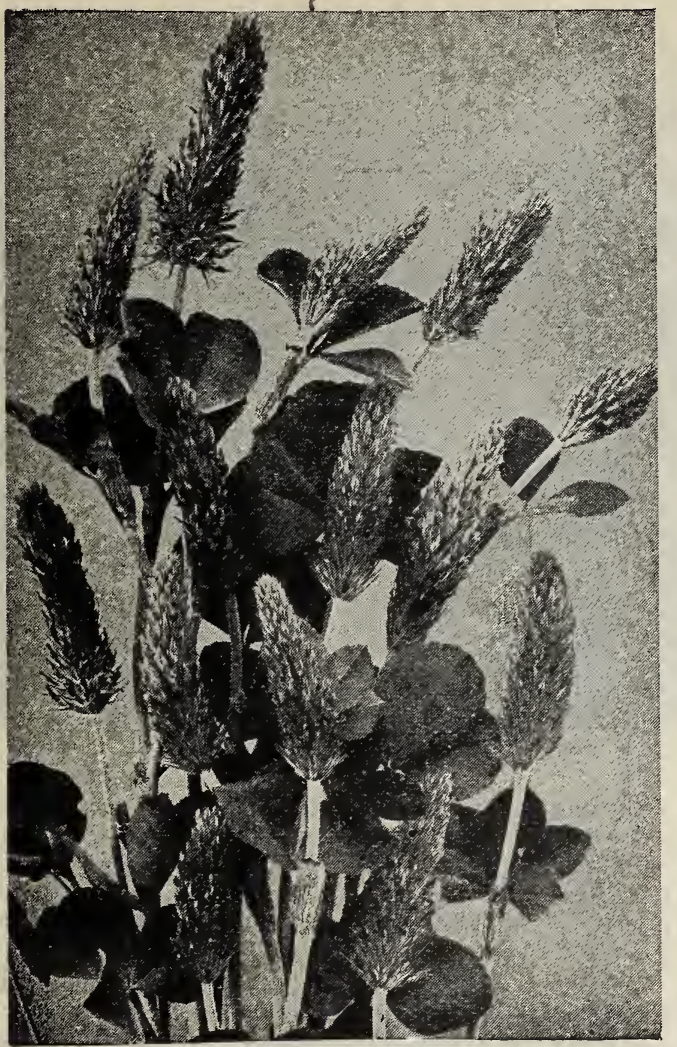

Crimson Clover.

\section{INOCULATE THIS \\ SEED WITH}

WHITE DUTCH CIOVER-Largely used in lawn and pasture mixtures, and is well adapted to our soils. It is voluntary in growth and will cover the ground well and makes a good pasturage. Generally sown in a mixture with other grasses; not suitable for hay. Price, per 1b. 70c.

CRIMSON CIOVER-This is our great soil improver and redeemer of worn-out lands. A crop of crimson clover plowed under is equal to a heavy application of stable manure, and is the cheapest and most effective improver of soils in the agricultural world. It is an annual plant, and is sown in July, August, September and October at the rate of 15 to 20 lbs, per acre. It has been very generally sown in corn at the last working in July and August, but we are rather inclined to advise the discontinuance of this method, as our experience has taught and shown us that these early seedings are very uncertain, and have cost our farmers hundreds of thousands of dollars loss in seed. We would rather recommend September and October seedings. Crimson Clover offers a cover crop for winter, early pasturage, and green feed for spring and nutritious hay crop and increased fertility of the soil. Every available foot of land on the farm should be sown in Crimson Clover. Price, per 1b. 15c; per bushel $\$ 6.50$.

\section{Alfalfa}

Alfalfa is acknowledged the king of all hay crops It will yield more cuttings and make larger yields of most nutritious hay than any other crop. Once established, it will last for years, giving four to five cuttings each season.

\section{PREPARATION OF SOII AND METHODS}

Alfalfa should be sown on improved soils, care being taken that the same is absolutely perfect in drainage, with a clay subsoil. It will not thrive on land that is inclined to be wet or where roots will reach water near surface. The land should be sown in cowpeas or crimson clover, on or two years previous to the seeding of the crop. It should then be limed at the rate of one to two tons per acre, and should be thoroughly and well prepared with a firm seed bed before seeding. The seed should be sown in September at the rate of 25 to $30 \mathrm{lbs}$. per acre, lightly covered and rolled. An application of 400 to $600 \mathrm{lbs}$. of pure bone meal per acre at the time of seeding will prove a paying investment. Alfalfa should be cut before it reaches full bloom which causes it to stool out better, and thicken root growth. Alfalfa should always be sown alone, without other grasses or clovers. If the land re quires inoculation, we recommend soil inoculation at the rate of 500 to 600 lbs. of soil derived from well established alfalfa fields, or inoculation of the seed with Farmogerm. In seeding grass and clovers, we recommend a mixture of 3 to $4 \mathrm{lbs}$. alfall'a seed per acre on all lands adapted to alfalfa. This gives the necessary inoculation in case the farmer determines to sow alfalfa in the future.

We have an exceptionally fine stock of high-grade American Grown Alfalfa Seed to offer this year testing over $991 / 2$ per cent purity, with a germination test of from 92 to 95 per cent.

Price, per pound, 30c; per bushel, $\$ 16.00$.

\section{OUR CLOVER AND GRASS SEEDS}

Represent the highest grades obtainable. Each lot accurately tagged for purity, germination and territory where grown.

\section{GOOD SEEDS ARE THE CHEAPEST}

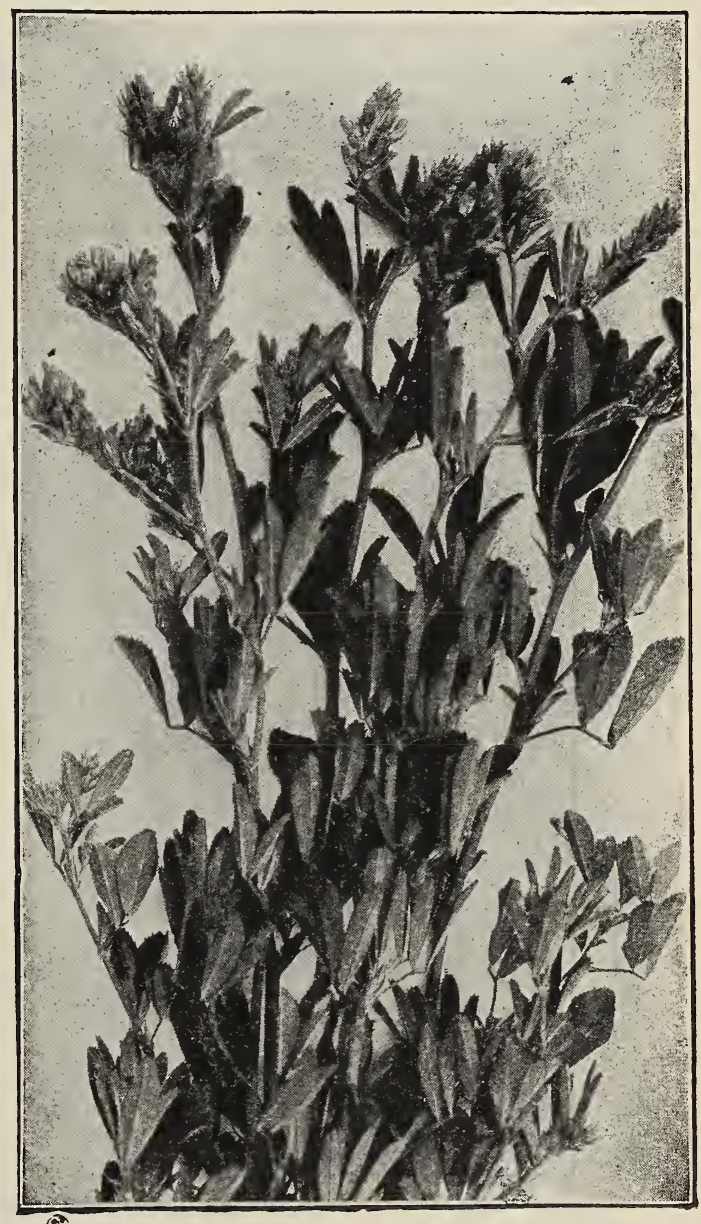

Alfalfa. 


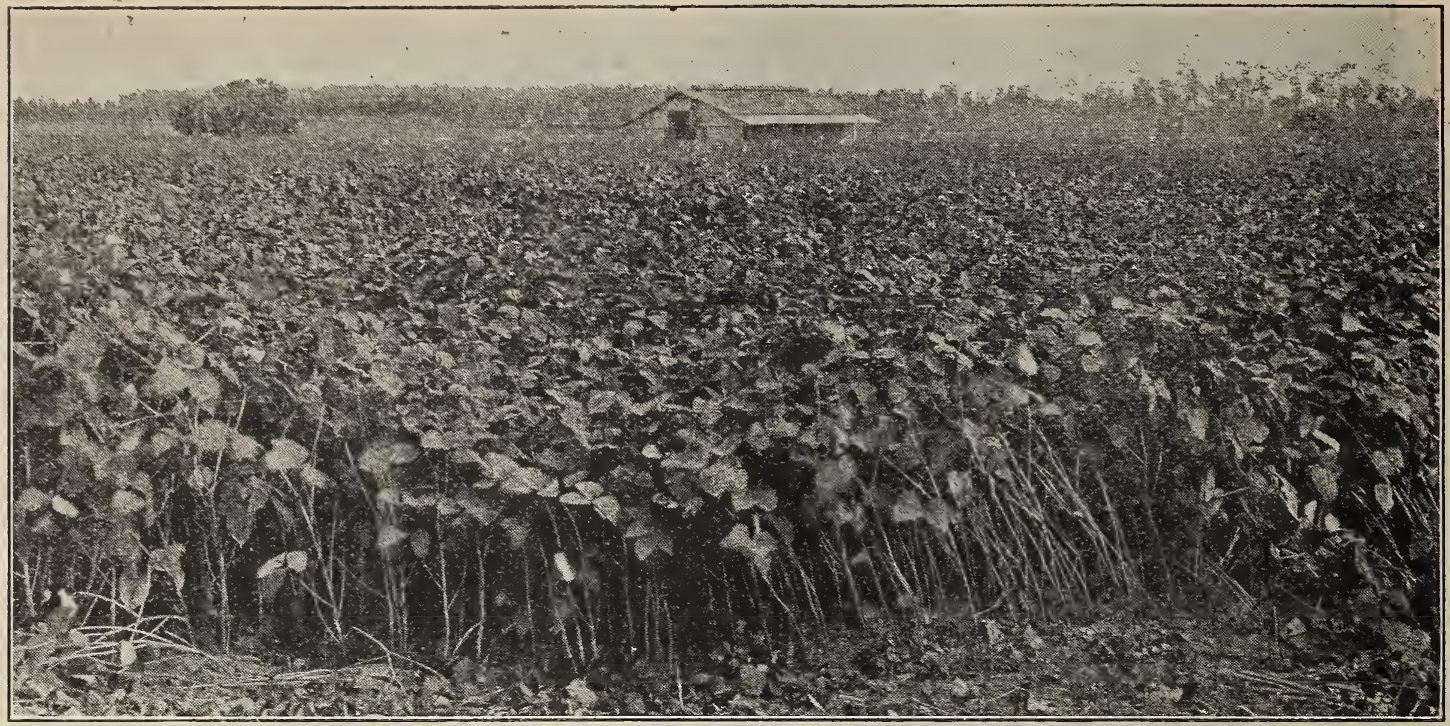

Field of Cow Peas.

\section{Seed Oats}

Our Seed Oats are all selected stocks, recleaned and sacked in even weight five-bushel bags.

BURT, or NINETY-DAY OATS-This is undoubtedly the best spring oat. It is very early in maturity, free from rust, hardy and a vigorous grower, making a large field of good, hard grain. Resembles the red rust-proof, but the grain is not as large or as heavy; growth is somewhat taller. Price, per bu. $\$ 1.10$; 10-bu. lots, $\$ 1.00$ per bu.; 25-bu. 10ts, 95c per bu.

VIRGINIA GRAY WINTER, OY TURF OATS-This is the old standard and favorite winter oat for Virginia, and is more generally sown than any other oat. Is very hardy, and a sure cropper. While generally sown in the fall, it can be sown in the spring up to about March 10th to 15th. Price, per bushel, $\$ 1.50$.

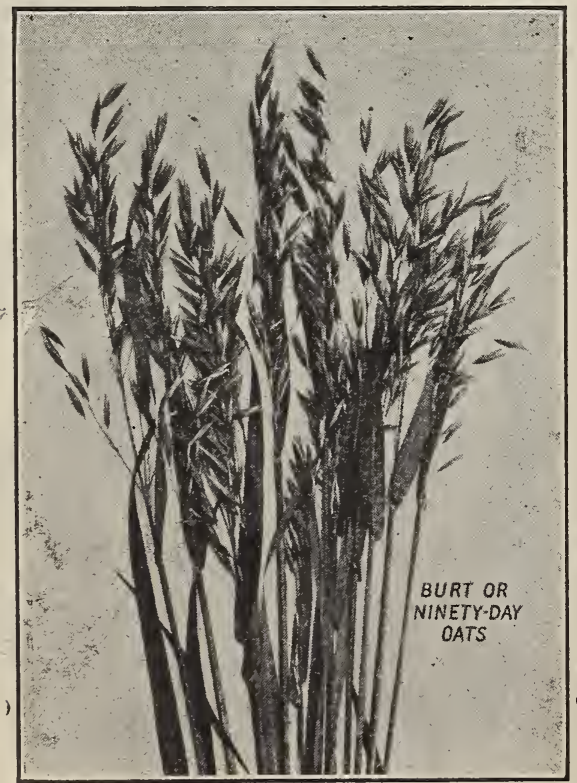

TEXAS RID RUST-PROOF OATS-A very popular and desirable oat throughout the South. Especially adapted for heavy soils of good fertility, where it yields abundant crops of large, heavy grain. This variety does not grow as tall as the Virginia Gray, and requires rather better land than the same. It is largely used for sowing with vetch and white bloom crimson clover as a hay crop. Can be sown either fall or spring. Price, per bushel, $\$ 1.00$; 10-bu. lots, 95e per bu.

FUIGHUMI OATS-This rust-proof variety is growing in popularity each year, and deservedly so. It is practically the earliest of all rust-proof varieties; very productive, and a sure cropper on good land. Price, per bushel, \$1.35.

APPIIR OATS-Improved variety of the RustProof type. Makes a strong, quick growing oat; large bunchy heads, with heavy grain. One of the best and most reliable rust-proof oats for the South. Price, per bushel, \$1.25.

\section{Soja Beans}

The use of Soja Beans is increasing rapialy everywhere, as farmers are beginning to realize what a valuable and important forage crop they are. Sown broadcast at the rate of one and a half bushels per acre, they make practically a balanced ration when cut for hay; sown with cowpeas at the rate of onehalf bushel of beans and one bushel cowpeas, they increase the value of the hay by 50 per cent. They are also unsurpassed as a hog pasture.

MANMOTH YEILOW-The largest growing and most popular of Soja Beans, requiring a full season for maturity. Surpasses all other varieties in yield for both forage and seed. Per bushel, about \$3.50.

TAR-FFII BLACKS-Slightly earlier in maturity than Mammoth Yellow. Heavy growth of vines. upright in habit, and growing in popularity wherever used. Per bushel, about $\$ 3.50$.

HOILYBROOK EARIY-Matures two to three weeks earlier than the Mammoth Yellow. Makes a good yield of forage and peas, and is very desirable on account of its earliness. Price on application.

VIRGINIA-This variety is fast growing in favor. Makes an excellent yield of hay, and its profuse leafage, fine stems and stalks, give a quality of hay almost equal to alfalfa. On account of its earliness, it is largely used for planting with corn. earlines, per bushel, on application.

Prices on all field seeds are constantly changing. Before placing your order, write us 'for firm prices on your requirements. This will give you an opportunity of buying at the lowest current prices. 


\section{FIELD, or COW PEAS}

Cowpeas are one of the most important, most advantageous, and best paying crops for the farm ers throughout the South. They produce hay, they produce ensilage, they produce excellent grazing for hogs and cattle, and they furnish the farmer with the best and cheapest fertilizer on the market. They can be sown from the first of May to the middle of August.

AS A HAY. They produce from one and a half to two and a half tons of the best nutritious hay relished by horses and all stock, leaving the land in a much better condition. They should be sown broadcast or in drills, at the rate of one and a half to two bushels per acre; the thicker the stand, the better quality of hay.

AS AN TrSIIAGE. They are unsurpassed, being more nutritious than green corn.

AS A FrRTIIZFR. Gathering the nitrogen and ammonia from the air, and storing the same in their vines and roots, they enrich the soil faster, and more lastingly than any method of fertilization known to the farmer, without extra cost. On good land, is it not necessary to fallow the entire crop-the vines can be cut for hay, and the stubble and roots will furnish the fertilizer for the following crop. Where it is desired to improve thin and worn-out lands with cowpeas, this can be done by applying two to four

\section{INOCULATE THIS SEED WITH FARMOGERM} hundred pounds of High Grade Acid Phosphate or 8-2-2 Guano per acre at time of seeding. In these cases, it is best to give the land the benefit of the entire crop by fallowing the same.

SEFDING IN CORN. Farmers in this section are sowing thousands of bushels of cowpeas in their corn at the last working. These peas can be fallowed after the corn is taken off, or they may be allowed to stay on the land, affording a splendid mulch and winter covering.

AS A HOG PASTURE. A mixture of Cowpeas Soja Beans, with Kaffir Corn, or common White Field Corn, will afford a most luxuriant grazing for hogs, and will minimize the cost of producing the meat for market.

Prices on Cowpeas fluctuate, and are subject to change.

BIACK PEAS-This is the standard variety, and very largely grown in Virginia. It is very prolific, making a fine growth of vine and leaves, and a good yield of peas. Rather inclined to shed its leaves, and is not considered the best variety for hay on that account. Makes a fine hog pasture. Per bushel, about $\$ 5.00$.

NEW IRA-An extra early maturing variety of upright growth. Not as heavy in forage as others, but very prolific in peas. Per bus.

WONDERTUL, or UNKNOWN-This variety makes an enormous and remarkable growth of vines, requiring full growing season. The vines are of the running habit, on account of which the hay is rather hard to cut and cure. One of the best varieties as a soil improver. Per bushel,

WHIPPOORWIII-An upright, early maturing variety of great popularity. Makes a good growth of vine, easily cut and cured. One of the best peas in cultivation. Per bushel, $\$ 4.50$.

CIAY-A vigorous grower, and a heavy yielder of hay, maturing a little later than the Black Pea Per bushel, \$4.75.

IRON-A variety of Cowpeas remarkable for its vigorous growth, and its disease resisting qualities. Retains its leaves and foliage longer than other varieties, and is on this account one of the very best for hay. It is also a very prolific bearer of pêas. Per bushel, \$4.75.

TAYLOR-A large speckled pea, making an abundant growth of vine, of upright habit. Heavy yielder of peas, and a good variety for a hay crop. Per bushel, $\$ 5.00$.

MIXED COWPEAS-A general mixture of the principal varieties grown. A great many farmers prefer sowing mixed peas for hay, as experience has shown that they get better and more hay than by seeding one variety. Per bushel, \$4.50.

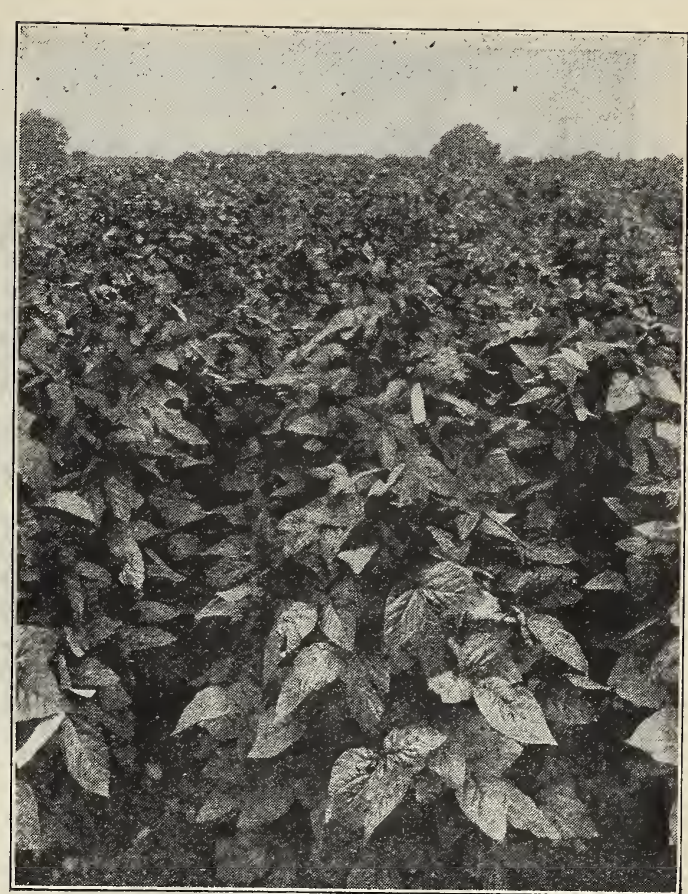

Soy, or Soja Beans.

MIXFD COWPFAS with SOJA BFAFS-For those of our customers who desire a mixture of cowpeas and soja beans, we are prepared to give them a splendid mixture in proper proportions. It is very desirable to sow soja beans with cowpeas, as the beans are upright in growth, and help to hold up the peas, besides adding considerable to the nutritive value of the pea. Per bushel $\$ 4.00$.

\section{EDIBLE VARIETIES}

FARTY RAMSFORN BT.ACFYF-A large second early black eye pea of splendid quality. A great favorite with truckers and market gardeners as a green pea. 1 lb. 30c; 5 lbs. \$1.00, postpaid.

FXTRA FARTX BIACK FYㅍ-An extra early strain of the well-known black eye pea. Of upright growth, bushy, very prolific in pods; of good flavor, and especially used for early marketing of green shelled peas. I 1b. 40c; 5 lbs. $\$ 1.50$, postpaid.

IARGPB BTACK EYE-A well-known large type of the original black eye pea. Later in maturity than Ramshorn and Extra Early, but more prolific and a sure cropper. 1 1b. 25c; 5 lbs. 75c, postpaid.

On account of the very short crop of Cowpeas, we are unable to name firm prices at this time. Write for special prices when in the market, and we will do our best to give you what you want.

\section{Ninety-Day Velvet Beans}

This new Velvet Bean is a great acquisition for Virginia farmers. It is the quickest growing, earliest maturing of the Velvet Beans, and unlike the other varieties, it will mature in Virginia. It is a wonderful soil improver and forage crop and the best of grazing for cattle and hogs. For the redemption of worn-out soils, this bean is unequalled. Peck, \$1.00; bushel, \$3.00.

\section{Canada Field Peas}

Canada Field Peas with oats make a very desirable hay. They should be sown in January or early in February to get best results. Sow at the rate of $11 / 2$ bushels of Oats, and 1 bushel of Canata Field Peas per acre. 


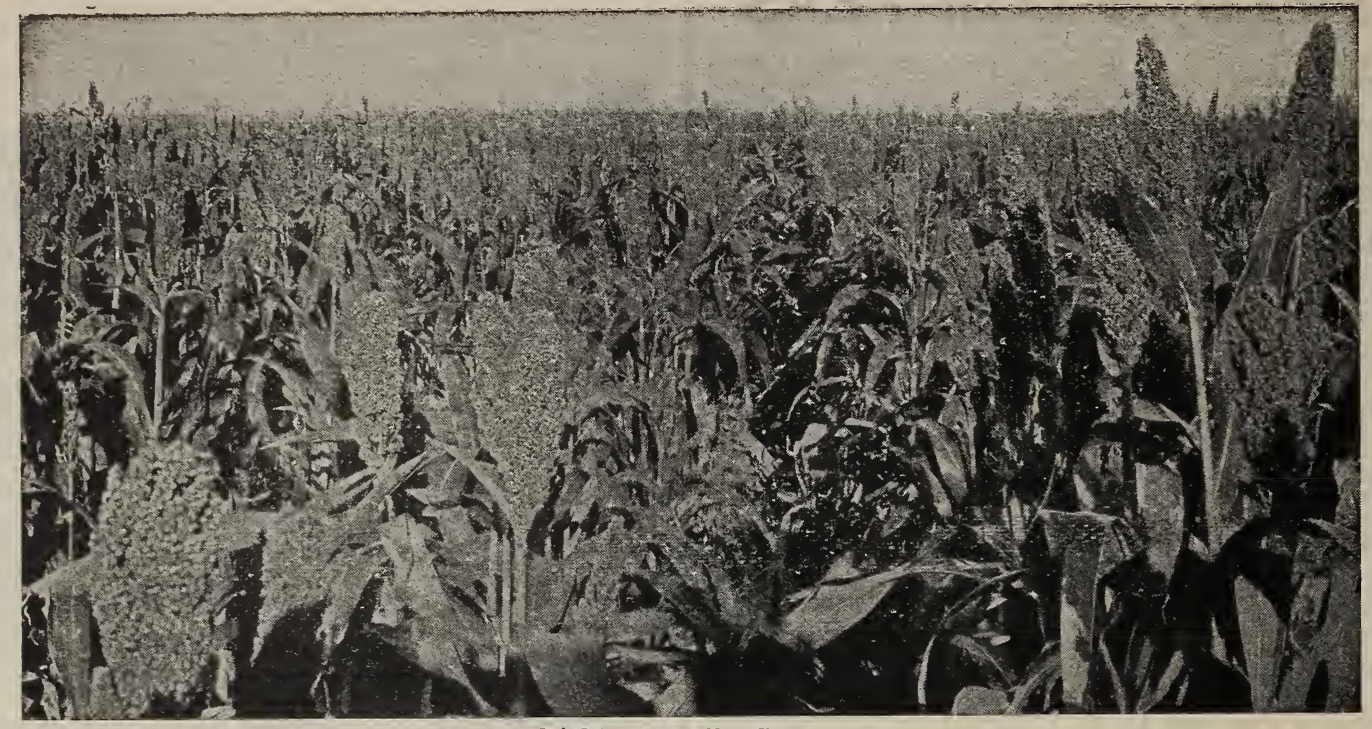

Field of Kaffir Corn.

\section{Golden Millet}

Golden Millet makes a large yield and most nutritious hay crop. Quick growing and most easily cured. Should be sown on good land only, at the while in bloom before seed hardens from the middle of Way to the end of July.

Tennessee Grown-Price, per bushel, $\$ 3.50$.

Southern Grown-Price, per bushel, $\$ 3.00$.

\section{Winter Rye}

Largely cultivated for pasturage in winter, for early green food, as a cover top, and for fallowing purposes in spring. Price on application in season.

Add for postage if ordered sent by mail.

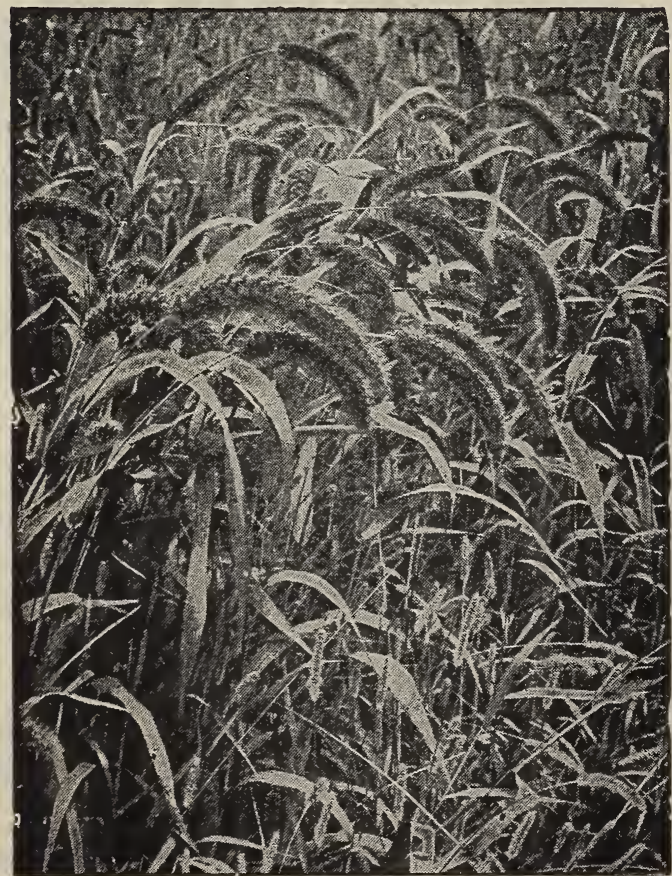

Golden Millet.

\section{Winter Barley}

Sown in the fall for winter and spring pasturage. Price on application in season.

\section{Seed Wheat}

We carry a full stock of all the leading varieties during seeding season. Price on application.

\section{White Navy Beans}

Grown for the dried bean only. Should be planted in June or July in 3-foot rows. Price, per qt. $30 \mathrm{c}$; pk. $\$ 2.00$.

\section{Kaffir Corn}

This is a very popular forage crop. Makes a heavy growth and is very nutritious. When allowed to mature the grain malses a valuable feed for stock or poultry. Kaffir corn is also sown with cowpeas to enable the cowpeas to grow up on the corn and make harvesting ,easier. Price, per 1b. 10c; bushel of $50 \mathrm{lbs}$. $\$ 2.00$.

\section{Sorghum}

SUGAR DRIP SORGHUM-A heavy yielder of nutritious forage; very juicy and sweet. Makes a large yield of syrup, which is of superior quality. Price, per 1b. 10c; pls. \$1.00; bus. $\$ 3.50$.

EARIY AMBER SORGHUM-This furnishes a large yield of very nutritious forage, and is used in the green state or cured. On good land it will yield 2 to 3 cuttings a year. It is highly recommended when quick growing, green food is desired. Price, per 1b. 10c; pk. $75 \mathrm{c}$; bus. $\$ 2.50$.

EARIY ORANGE SORGHUM-Similar in growth and character to the Early Amber, but considered a heavier yielder. Price, per 1b. 10c; pk. 75c; bus. \$2.50.

If your Grain crops are of a sickly appearance and are not showing any signs of improvement by Irarch or April, run a sharv tooth harrow over by Inarch or April, run a sharp tooth harrow over pounds Nitrate of Soda per acre, then follow with pea weeder crosswise. Results will surprise you.

ADD FOR POSTAGE IF ORDERED SENT BY MAII. 


\section{Vetches}

HAIRY, or SAND VITCH-This great forage crop is rapidly becoming a favorite throu ghout the South. Generally sown with oats, in which combination it yields heavy crops of the very best kind of hay. Sow in September at the rate of $20 \mathrm{lbs}$. of Vetch and $1 \frac{1 / 2}{2}$ bushels of oats per acre. It has been customary to sow from 30 to $35 \mathrm{lbs}$. per acre, but our experience has taught us that by seeding 15 to 20 lbs. with oats, we get much better hay, and have much less trouble in cutting and curing the same. A mixture which has proven very successful in this section is $1 \frac{1 / 2}{2}$ bushels of rust-proof oats, $15 \mathrm{lbs}$. Hairy Vetch, and $10 \mathrm{lbs}$. of white bloom crimson clover per acre. We recommend this mixture, and know it will please. Hairy Vetch is a great improver of soil, and wherever it is used, the land is left in much better shape. Price, per 1b. 15c; $50 \mathrm{lbs}$. at $13 \mathrm{c}$ per $1 \mathrm{~b}$. SPRING, or OREGON VEFCF-Adapted for spring sowing, and usually sown with some variety of spring oats. Has the same characteristics as hairy vetch. Per lb. 10c; $100 \mathrm{lbs}$. $\$ 8.00$.

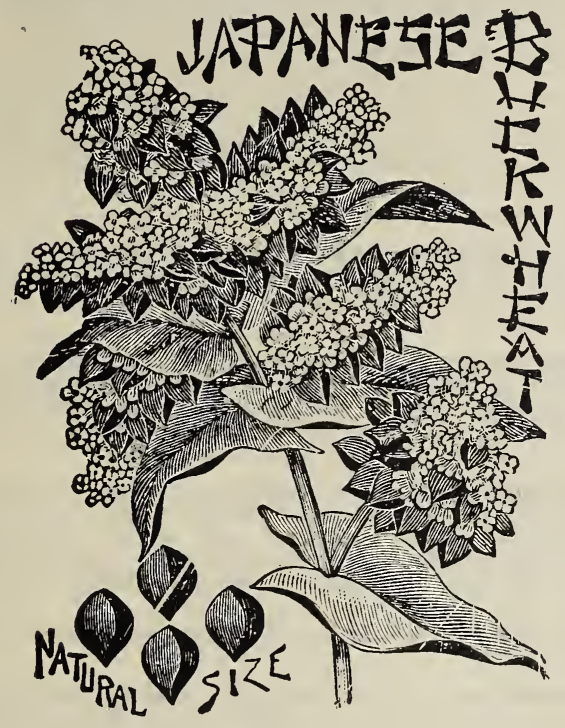

\section{Buckwheat}

A very desirable crop for late summer. Easily grown and affords splendid poultry food. Is also considered an improver of soil. We recommend the seeding of buckwheat and crimson clover together at the rate of 15 to 20 lbs. of crimson clover and $1 / 2$ bu. of buckwheat per acre. The buckwheat will grow rapidly and shade the crimson clover from the hot sun, insuring a stand of clover at all times. When buckwheat is ripe, it can be harvested and stored away for chicken feed. In this way, you can make two crops from one seeding, and are always assured a good stand of crimson clover which is generally very hard to get in the early seeding. TAPANFSE-This variety ripens a week earlier than Silver Hull, and kernels are larger, and makes a heavier yield. Price, per peck 75c; bushel $\$ 2.50$. SIIVIR HUII-A favorite sort recommended for the fine quality of flour. Price, per peck 75c: bushel $\$ 2.50$.

\section{Dwarf Essex Rape}

Excellent for grazing for sheep ho s or any kind of stock; furnishing rich and nutritious pasturage 6 to 8 weeks from time of sowing. Is largely used for green feed for poultry. Can be sown most any month in the year, at the rate of 5 to $81 \mathrm{bs}$. per acre. Price. per 1h. 15c; 10-1b. lots at 10c; $50 \mathrm{lbs}$ at 9c per 1b.; 100 1bs. $\$ 8.00$.

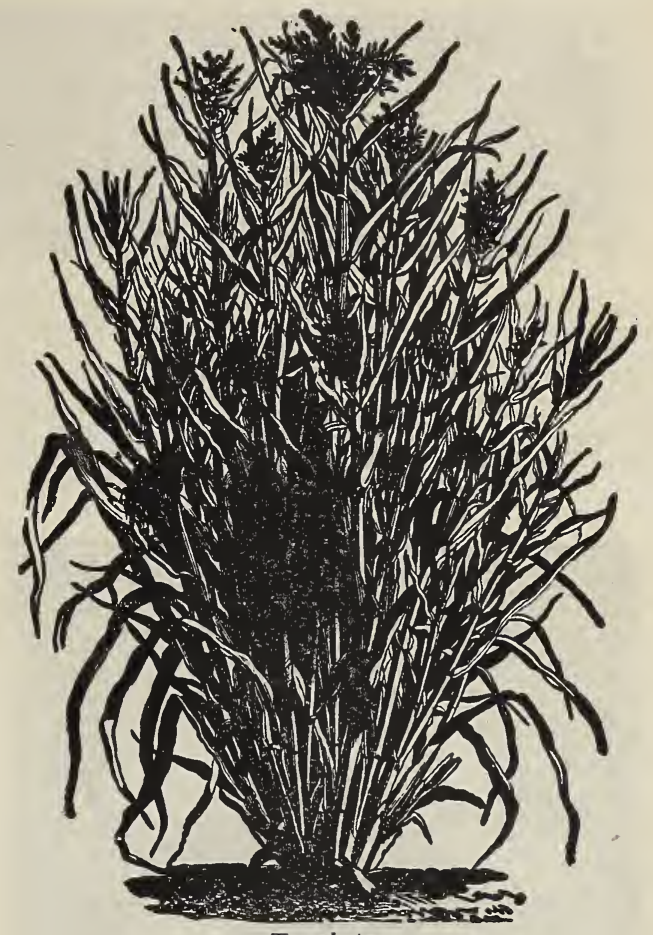

Teosinte.

\section{Teosinte}

This is a valuable fodder plant, resembles corn in orowth but with larger leaves and sweeter stalks, which yield enormous crops; if planted on rich soil, can be cut 5 to 6 times a year. Will grow to a height of from 10 to $14 \mathrm{ft}$. Drill in May or June at the rate of 2 lbs. per acre. Rows 4 feet apart. Price, per 1b. 60c.

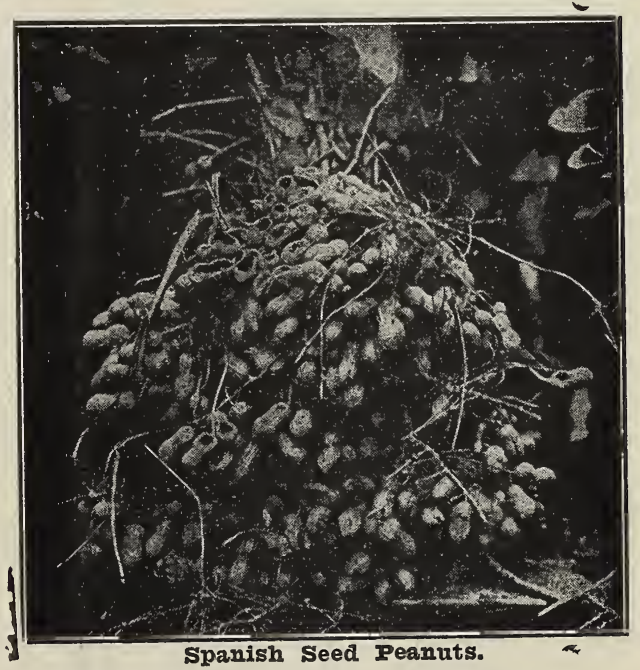

\section{Spanish Seed Peanuts}

We make a specialty of Hand Picked and Hand Shelled Spanish Peanuts for seed purposes. Our stocks are carefully selected, screened to a uniform size, and carefully handled throughout, insuring a seed of highest germinating qualities, and free from imperfect and split peas. Our peanut planters realize the superiority of our Hand Shelled stock over the general run of seed as they can figure without loss on the exact quantity per acre to get a full and uniform stand. Price fiuctuates. Current price on application. 


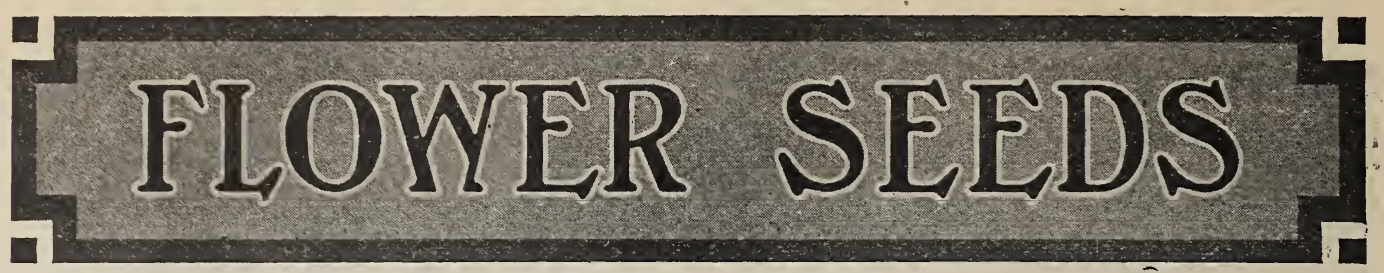

Our flower seed list comprises the best selections of all standard varieties of flowers usually found in the garden, and all varieties listed here are popular and are deserving of a place in every flower garden. The letter " $\Lambda$ " after the name of the flower indicates that the flowers are annuals, blossoms only the first year, and the seed should be planted each year. The letter " $P$ " indicates that the variety is a perennial, and blossoms for several years after sowing.

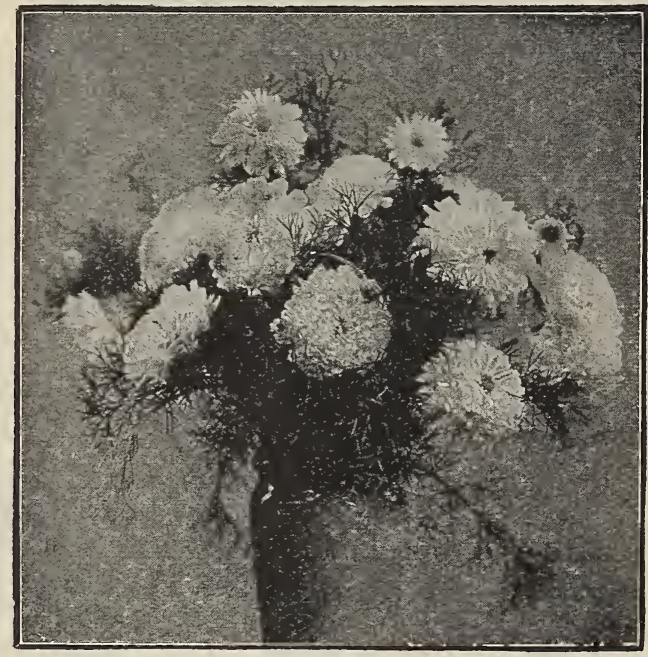

Asters.

AGERATUM (A)-A beautiful hardy annual. The flowers are borne in dense clusters and are very useful for bouquets. The plants are very attractive in the garden, being covered with bloom nearly all summer.

Mixed Colors-Pkt. 5c.

SWEET AIYSSUIM (A)-A hardy annual which begins to flower when very young, and is literally covered almost all the season with its sweet white flowers. It is especially adapted to borders or for rock work in the summer, and may be used effectively in window boxes for blooming. Pkt. 5c.

AMARANRHUS (A) (Iove Iies Bleeding)-These plants afford brilliant contrasts of color, being useful for tall border and groups, also where foliage effects are desired. The leaves and stems are of different shades of red, blended with green; two to three feet high. Plrt. 5c.

ANTIRIJINUII-Snapdragon (A) - Well known, show.y and u'seful border plants, producing flowers of a great variety of brilliant and handsome colors. Very effective in beds, succeeding in any good garden soil. Plit. 5c.

ASTERS (A)-These well-known, beautiful and popular annuals are very desirable for bedding, being in bloom when most other plants are over. Very useful for cut flowers and for bouquets.

German Quilled (China Aster) - The familiar double Aster with quilled petals. Exceedingly showy and excellent for cutting for vase decorations. The large, brilliant, daisy-like flowers with yellow centres are produced in profusion. Pkt. I0c.

Victoria-The most popular variety of Asters, and very desirable for bedding, and useful for cut flowers and baskets.

In separate colors, pink, white, and blue, per package, 10c; mixed colors, per package, 10c.
BAISAM-Touch-IMe-Not (A)-Also known as "Lady Slipper." A tender annual with brittle stems and foliage. Grows about 12 inches high. Flowers both single and double, in bright colors and variations; are wax-like and very attractive. No flower is more easily cultivated, and it succeeds in most any good soil.

Double Irixed-Plst. 5c.

BAISAMI PEAR (A)-An ornamental climber grow ing to height of 12 to 15 feet. The fruit is pearshaped, and when preserved in alcohol is said to be useful in relief of pain. Pkt. 5c.

BACFFIOR'S BUTTONS-Globe Amaranth (A)A well-known and popular everlasting flower which forms bushy plants about 2 feet high, and bearing sometimes hundreds of flowers. - Excellent as border plants, and very useful for winter decorations. If cut when well matured will retain their beauty throughout the winter.

Mixed-Pkt. $5 \mathrm{c}$; oz. 75c.

BAIIOON VINE (A) - A rapidly growing climber of attractive foliage, and deriving its name from the Inflated Seed Pod, resembling a balloon. Plet. 5c.

CARNATIONS (P)-These well-known flowers are easily grown from seed, and very free blooming. the flowers being bright-colored and with a most delicious clove-like fragrance. Excellent bloomers in the garden or for winter flowering.

Marguerite-An extra vigorous race, especially adapted for out-of-door culture The plants are trim in habit, perpetual and flower abundantly in 5 months from sowing the seed. They are highly fragrant, and have beautiful double flowers. Pkt. 10c.

Double IMixed-A mixture of all colors and types. Pkt. 10c.

CAIENDUIA - Pot Marigold (A) - Very hardy annual, one foot high. Has showy flowers blooming until frost and producing a fine effect in borders. It is of easy culture and is desirable for ers. It is of easy culture and is desirable for
rather inferior soils, where less sturdy flowers do not thrive.

Mixed Varieties-Plt. 5c.

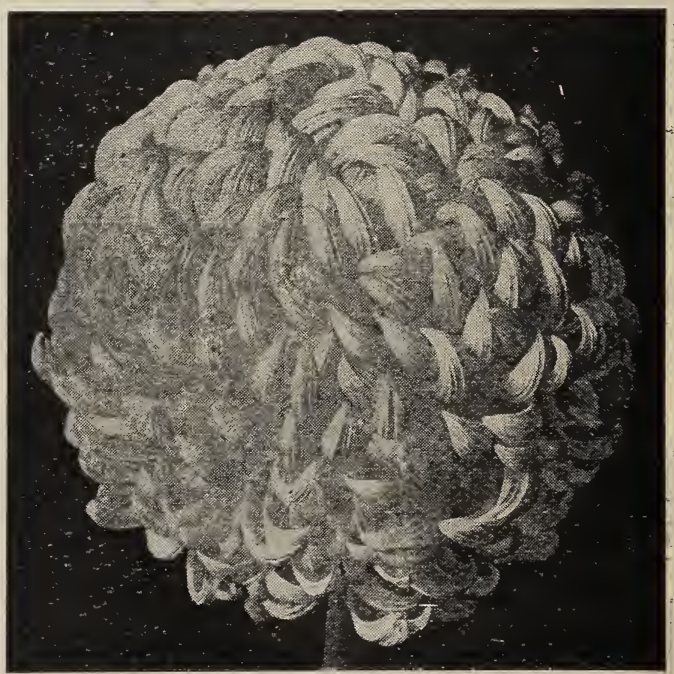

Chrysanthemum. 


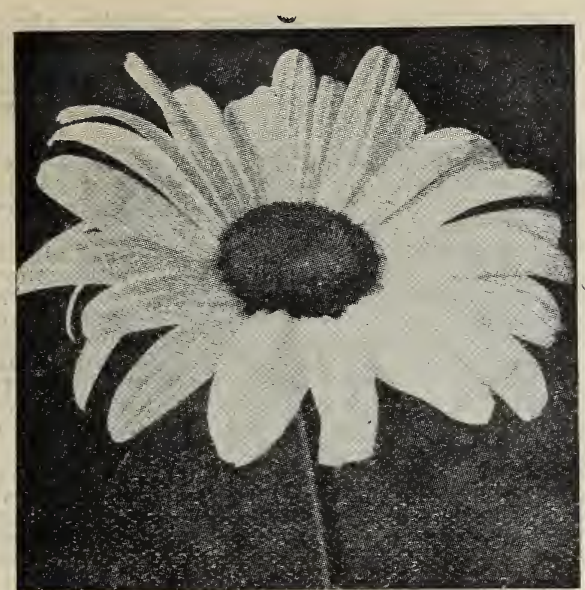

Shasta Daisy

CANDYTUE (A)-Popular favorites, flowering profusely the whole summer. Very valuable for edgings and. borders, fairly covered with masses of white and various colors. Height 1 foot. Of easy culture.

white-Pkt. 5c.

Crimson-Pikt. $5 \mathrm{c}$

Iancy Mixed-Pkt. $5 \mathrm{c}$; oz. $40 \mathrm{c}$.

C.AIIIOPSIS OR CoREoPSIS (A)-Beautiful showy summer bedding annuals with large bright flowers of golden yellow, varied with rich brown. Excellent for cutting and decorations.

Mixed-Pkt. 5c; oz. 35c; $1 / 4$ 1b. 50c.

CANTrRBURY BrI工S-Cacpanula, Cup and saucer (P)-Handsome, hardy biennial of stately growth, rich color and profuse bloom. Succeeds best in light, rich soil and in the fall should be transplanted or thinned to 18 inches or 2 feet apart and given some protection in severe winter weather. Has large, bell-shaped flowers which are strikingly effective; colors white, and various shades of violet, rose, lilac and blue. Height, to 4 feet. One of the wild forms of Campanula is the "Blue Bells of Scotland." Pkt. 5c.

CrIOSIA-Cock's Comb (A)-A half hardy annual, growing 6 to 8 inches high, bearing a wide wavy blossom that resmbles a Cock's Comb. Fine for massing or border work. Pkt. 10c.

Plumed Variety-Pkt. 10c.

Comb variety-Pkt. 10c.

CENTAUREA, GYMNOCARPA-Dusty Miller (P)Valuable because of its silvery foliage, and graceful drooping habit of growth. Half hardy perennial; one-half to two feet high. Pkt. 5c.

CHNTAURTA "CORN FIOWRR"-IMixed colors, plit. 5c.

san-

CHRYSANMHTIIUI (A)-These, annual Chrysanthemums have a charm of their own. The bloom ing season is from very early summer until frost, and their gay colors make beds or borders attractive during those hottest weeks of summer when flowers are apt to be scarce.

Double Mixed Varieties-Pkt. 10c.

Single Mixed-Plt. 5c.

Cosmos (A) - These well-known flowers are of easy culture and are almost indispensable for cutting and garden decorations, their lovely blossoms being produced in greatest profusion after inost other flowers have succumbed to frost. Few flowers have grown more into popularity in late years than the Cosmos, and we recommend them to all wanting large plants in their gardens.

Mammoth Mixed-The flowers are double the size of the old, large flowering Cosmos, measuring from 3 to 4 inches across. The petals are large, overlapping, forming perfectly round flowers, deeply ribbed and of good substance. Pkt. 10c.

DAISY (P) - These are charming little plants for edging and borders. The daisy has been so far improved by selection and careful cultivation that good seed will give at least 80 per cent of double flowers that are as large as any of the named sorts that are propagated by the division of the roots and are sold at high prices. The plants bloom well in the house and are splendid for early spring and summer flowering when planted in a slightly shaded situation. Tender perennials, about 6 inches high.

Mixed Colors-Plst. $10 \mathrm{c}$

White Colors-Bkt: 10g?
AFRICAIT DAISY-Forms compact plants about one foot high. Branches freely and is covered with daisy-shaped flowers of a glossy yellow, with dark centers, blooms entire summer. Pkt. 5c.

SHASTA DAISY-Flowers four inches in diameter, and blooms for months, easily grown. Pkt. 10c. DIGITAIIS, or FOX GIOVI (P) - A stately, oldfashioned border plant affording dense spikes of brilliantly colored flowers which are terminal and half as long as height of the plant. Colors, white, lavender and rose. Does not usually bloom until the second year. Thrives best in cool, shady locations.

Fine Mrixed-Pkt, 5c.

DIANTHUS, or PINKS (P)-These popular flowers, commonly known as Chinese and Japanese Pinks, have been for a long time very popular and deservedly so. In diversity of rich and beautiful markings they have but few rivals, and in ease of culture, freedom of bloom and almost certain satisfactory results, they stand close to the Nasturtium. Hardy biennials blooming the first year from seed. So easily grown from seed as to be rarely treated as biennials. Seed may be sown in the open ground any time in May.

Chinensis-The familiar old Chinese or Indian Pink, easily grown and very showy. Our mixture contains a large assortment of varieties. Plst. 10c. ESCrSCroITzIA - California Poppy (A) - The beautiful State flower of California. Blooms almost continuously throughout the season. A bed of these in full bloom gives a brilliant color effect. The foliage is finely cut and has a bluish tinge, delicate and very attractive. They are of the easiest culture. Can be sown in any soil, but the better the soil the larger the plants and blossoms. It is best to sow the seed in the garden where the plants are to remain, as they do not transplant easily. Pkt. 5c.

FORGFT-MI-NOT - Myosotis (P) - The favorite old border plant that succeeds best in moist situations. It comes into blooming early and the little star-shaped flowers appeal to every heart. Hardy perennials. Pkt. 10c.

FOUR O'CIOCK-Marvel or Peru (A)-A wellknown favorite plant, bearing freely funnel-shaped white, red and striped flowers, which open about four o'clock in the afternoon, remaining open all night; and usually are closed before noon the next day. Sow seed in spring in open ground in any good garden soil. The plants should be given plenty of room, about three feet apart. Pkt. 5c

GAIIIARDIA (A)-A very showy, hardy, garden plant, with brilliant flowers in scarlet and yellow, blended and shaded. Blooms freely from. early summer till autumn. Grows one and one-half to two feet high, and the blossoms are borne on long. slender stems. Pkt. 5c.

HOIIYHOCK (P)-Entirely different and more beautiful than the plant of twelve years ago, being much more compact in growth, the flowers larger more richly colored and of better form. For a background to a flower garden nothing is better. Height 5 feet. Tie to stakes if the stalks show a disposition to fall. The double varieties are the most desirable.

Double Irixed Varieties-Pkt. 10c.

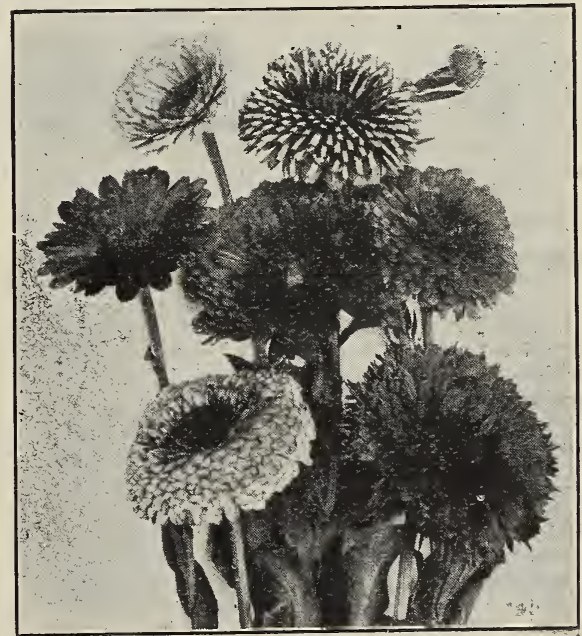

Calendulas 


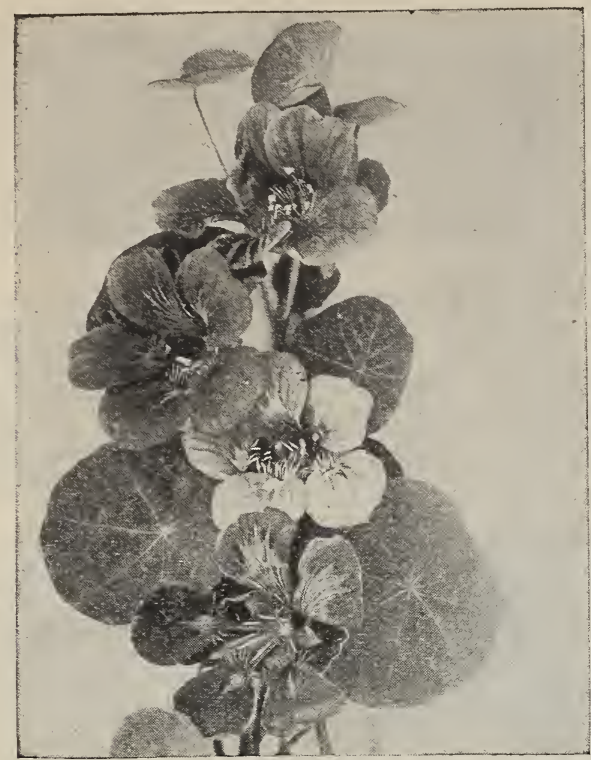

Nasturtium.

HבITOTROPᄅ (P)-May be grown from seed first season, very fragrant. Height two feet. Mixed colors, pkt. 10c.

KOCHIA, or BURNING BUSF-Grows from two to two and one-half feet high, is densely covered with small feathery light green foliage, which, as the summer advances gradually changes to crimson. Very ornamental, and of easy culture. Pkt. 5c.

IARKSPUR (A)-The Larkspur is one of the handsomest and most useful of plants. The colors are extremely beautiful and in mixed borders its profuse masses of purple, white and red show splendidly, and for large gardens is invaluable. Height, 12 inches.

Double Dwarf Varieties Mixed-Pkt. 5c.

IOBFIA (A)-Profuse blooming little plants, of great value for edging, hanging baskets or vases. It is completely covered with flowers for a long time. If given plenty of water they may be kept in flower all summer. Pkt. 10c.

IOVI-IN-A-MIST-Nigella (A)-A hardy annual one-foot high, with finely cut foliage. Oddly shaped blossoms in blue and white, and curious seed pods. Of easy culture. Pkt. 10c.

MARIGOID (A)-A hardy annual, shrubby plant, in dwarf and tall varieties, growing from 6 inches to 3 feet nigh. Foliage bright green, deeply cut, and graceful. The flowers are various shades of yellow and brown. The tall varieties are very valuable for large bedding or background work, and the dwarf varieties for borders. No flower garden seems complete without this fine oldfashioned plant.

African-The best tall variety with large, double blosisoms. Plet. 5c.

Dwarf Irench, Double Mixed-Pkt. 5c.

MIGNONITTP (A)-This popular little flower is well known as one of our most fragrant plants, and a universal favorite. If sown at intervals in spring and early summer it will bloom until killed by frost. Thrives best in a cool temperature. Pkt. $5 \mathrm{c}$.

NASTURTIUM (A)-Probably the most popular and easily grown flower in our list, and remains longer in bloom. In favorable soil the flowers are produced in abundance throughout the season. Nasturtiuns prefer dry, rather rocky soil, such as we usually call "poor" soil, and bear their flowers in such locations in greater profusion than in a rich garden, where they run too much to leaves.

Dwaxf Varieties Mixed-This mixture contains all of the choicest and prettiest flowers of the Dwarf variety. The plants form a small, round bush, 12 to 16 inches high, which is a mass of blooms all summer. Plst. 5c; oz. 10c; 1/4 1b. 35c; 1b. $75 \mathrm{c}$.
Tall Varieties Mixed-This mixture contains all of the choicest and prettiest flowers of the tall variety, are of quick growth, covering a whole hedge or trellis in a short time. The brilliant blossoms almost cover the plant from top to bottom. 5c; Oz. 10c; $1 / 4$ 1b. 25c; 1b. $75 \mathrm{c}$.

PANSY (P)-No description is needed of these little favorites, and it would be hard to find a garden whose charm is not in a large measure dependent upon their marvelous coloring.

Superb Pansy INixture-This is a mixture of all the giant flowering varieties, all the plain colors, faced sorts, ruffled edged and rare sorts, also the varieties exquisitely striped. The seed is saved from the most famous pansy gardens, from exhibition flowers. These pansies are wonderfully beautiful in every way and the very best there are The small difference in the cost of this seed over the other seed is covered one hundred-fold in satisfactory results to the grower. Pkt. 20c.

Giant Trimardeau Mixed-The largest flowering type of Pansy called the French strain. The top petals are larger than the three lower ones and are beautifully marked. The plants are vigorous, compact growth, with immense, three-blotched flowers. Pkt. 10c.

rine Iarge rlowering IMixed Pansy-This seed is saved from very good varieties, the flowers are small in comparison with the fine sorts but the colors are good. Pkt. 5c.

PFTUIA (A)-There is no bedding plant of easier culture than the Petunia, and few that make a gayer appearance when in full bloom. They are easily grown and very popular for bedding. They thrive best in a warm, suny location. The shape of the flower is similar to that of the Morning Glory. Sow the seed thinly where the plants are to remain, or for early blooming sow in the house in boxes.

Single Irixed-Pkt. 5c.

POPPY (A)-Hardly any class of plants afford the same brilliant colorings and showy display. They are of easy culture, the seed being sown where they are to remain. Thin the plants 6 to 12 inches apart.

Shirley Poppy-Pkt. 10c.

Tulip Poppy-Pkt. 10c.

Double Mixed-All the fancy and named double varieties mixed. Pkt. 5c.

PORTUIACA (A)-Low-growing or creeping tender annual, 6 to 8 inches high, and bearing glossy, cup-shaped blossoms in very brilliant and gorgeous cow slowly and should be started under glass or when the weather is hot: These flowers love the sunshine and do best on rather dry ground.

Mixed-This is an extra fine strain with very large blossoms and splendid colors. Pkt. 5c.

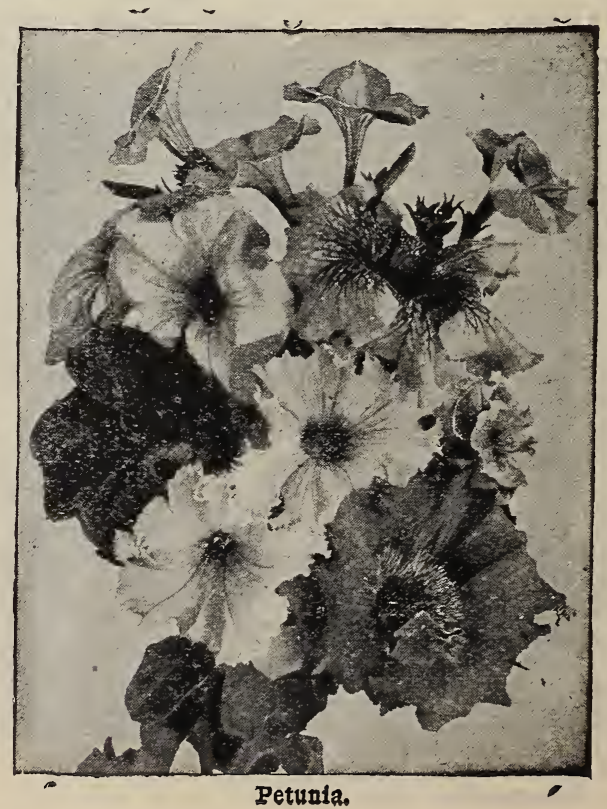




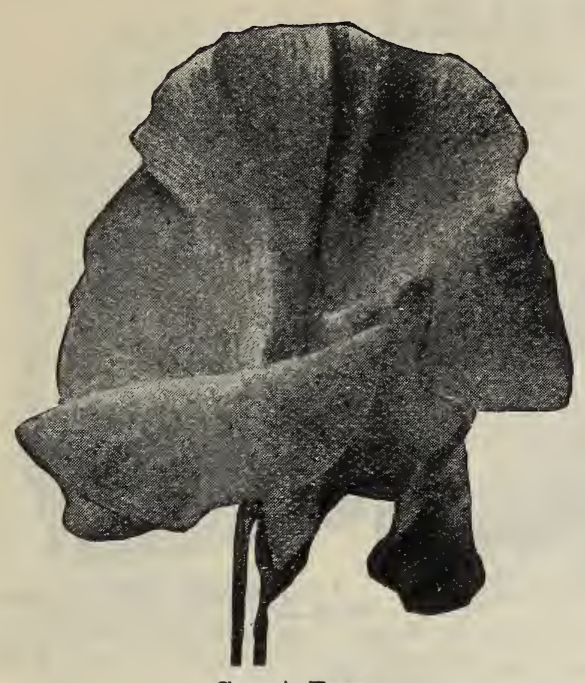

Sweet Peas.

PHIOX DRUMMONDI (A)-One of the prettiest and most popular of garden annuals. Makes very attractive beds, and continues to bloom throughout the summer. Sow in April, in open ground, or can be started earlier indoors.

Grandiflora Iarge Flowering Mixed-A great improvement on the common type, both heads and florets being nearly twice as large. Pkt. ivc.

Fxtra Choice Mrixed-This mixture is unexcelled for profusion of bloom and wide range of brilliant colors. Pkt. 10c.

PRIMROSE (A)-Green-house or pot plants, bearing trusses of large single or double blossoms in bright colors, as well as soft tints. Sow the seed in April or May for winter blooming. Pkt. 5c.

RICINUS-Castor Oil Plant (A)-Luxuriant rapidgrowing annuals with palm-like leaves. Excellent for background or centre of beds of foliage plants, the effect being especially striking after the brilliantly colored fruit is formed. Pkt. 5c.

SAIVIA SPIENDENS-Scarlet Sage (A)-A wellknown favorite bedding plant which bears magnificent spikes of scarlet flowers from July to October. Although perennial, it blooms the first year from seed, and there is really no flower that can rival it in splendid color. Excellent for cutting. Pkt. 10c.

SENSITIVE PIANT (Mimosa) (A)-Curious and interesting little plants with pinkish white flowers. The leaves close and droop when touched. Pkt. 5c.

SCABIOSA (Mourning Bride or sweet Scabious) (A)-Have perfectly double flowers, are useful for cutting, they are gracefully borne upon long tender stems well above the foliage and makes a beautiful cut-flower. Height 2 feet. Plkt. 5c.

STOCKS, DWARF GFIMLAN-Ten Weeks (A)Desirable for bedding or pot culture. They bear an immense quantity of fragrant blooms, each plant forming a perfect bouquet, and are splendid for cutting. Pkt. 10c.

SUNFTOWER-Mammoth Russian (A)-Pkt. 5c; $1 / 4$ 1b. 15c; 1b. 25c, postpaid.

SWFET PFAS (A) - superb spencer sweet Peas in Separate Colors-Pure white, shell pink, dark pink deep maroon, lavender, red and blue. Pkt. 10c; oz. 25c; $1 / 4$ 1b. $75 \mathrm{c}$.

Superb Spencer Mixture-A new race or type of sweet peas with extra large flowers, fully double the size of the older forms under good cultiva.the size of the older forms under good cultiva.-
tion. The Spencers lave wavy and fluted-edged petals, which with their rich coloring give an almost orchid-like appearance. The Spencer type will not stand careless cultivation, but if you give them you for the extra trouble by their exceptional size and beauty. This is a splendid, well-blended mixture of all true Spencer types only. All colors, mixed. Pkt. 10c; oz. 20c; $1 / 41 \mathrm{~b} .60 \mathrm{c} ; 1 \mathrm{~b}$. \$2.25.
SWFFT WIIIIAM (P) -A beautiful class of hardyfree blooming plants of extreme richness and diversity of colors. Produces a fine effect in beds or mixed flower borders. Pkt. 5 c.

VFRBENA (P)-These well-known flowers are splendid for beds or massing. Flowers of most brilliant colors, blooming from early summer till late in the fall. Verbenas grown from seed are always thrifty and do not rust. Sow early in house, or out of doors in April.

Pure white-Plet. 10c.

Iravender-Pkt. 10c.

Mixed Colors-Pkt. 5c.

WAIIFIOWER (P)-This is a fine bedding plant, but it is more often grown as a pot-plant and for this purpose is well adapted. The flowers are very fragrant and usually of various shades of yellow, brown and reddish brown. An oldearly in the rear in boxes and transplant. Pkt. 5c.

ZINNIA (A)-For georgeous sümmer and fall display the Zinnia is unsurpassed the flowers are perfectly double, resembling Dahlias, and almost every shade of color. For bedding and massing they are particularly suitable.

Tall Double Mixed Colors-Plkt. 10c.

Dwarf Double Inixed Colors-Pkt. 10c.

\section{Vines, or Climbers}

CYPRESS VINF-A tender climbing annual, with soft fern-like foliage and small star-like flowers. Height about 15 feet. Pkt. 5c.

MORNING GIORY-One of the most popular of all climbers. They grow rapidly to a height of about 15 feet and bear abundantly brilliant flowers of various colors.

Mixed Varieties-Pkt. 5c.

Imperial Japanese-Pkt. 10c.

MOON VINF, or FVFIING GIORY - Beautiful rapid climbers, bearing large white flowers which open in the evening and on cloudy days. Pkt. 10c.

DOIICFOS, or HYACINTH BEANS - A tender climbing annual, rapid growth and splendid for covering a trellis. Pkt. 5c.

\section{Gourds}

Ornamental Mixed-Package 5c; oz. 20c.

NFST FGG-In size, color and shape, like a hen's egg. Vines make good screens. Pkt. 5c.

DIPPFR-The handles grow curved if on the ground; straight if on a frame. Pkt. 5c.

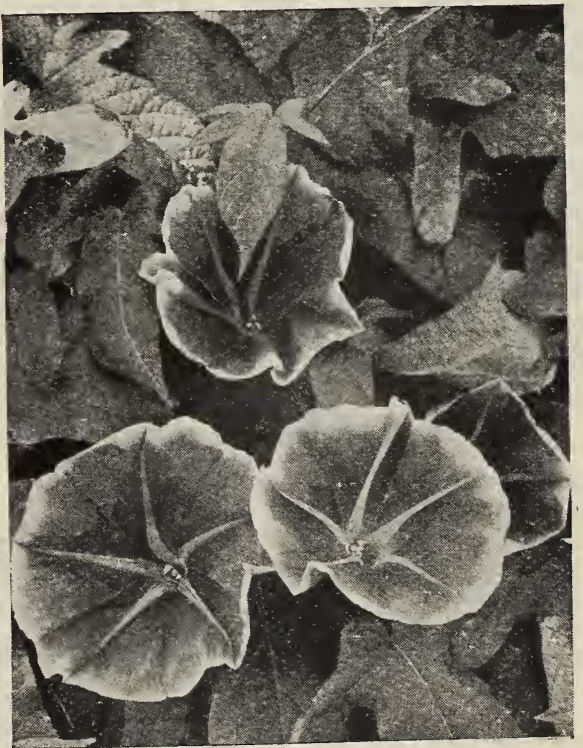

Japanese Morning Glory. 


\section{POULTRY SUPPLIES}

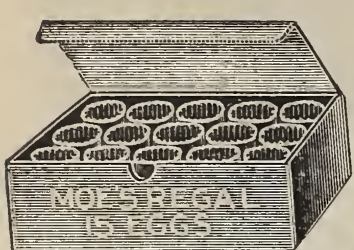

RFGAT, FGG CARRIIR. Ona of the most practical and safest packages for sending eggs by parcel post, especially recommended for hatching eggs. Price: 15-egg size, 25c each; 30-egg size, Noc each, postage prepaid. $\$$ Not prepaid, 15-egg size, size, $\$ 3.75$ per doz.

\section{JUNIOR}

CFICK

\section{IFEDIRS.}

A long shaped

feeder for baby
chicks. Very convenient and sanitary. Price: 12 - inch feeder, $35 \mathrm{c}$ each; 20.

inch size, $45 \mathrm{c}$ each, postpaid. ITot postpaid, 12-inch size, 25c each; 20-inch size, $35 \mathrm{c}$ each.

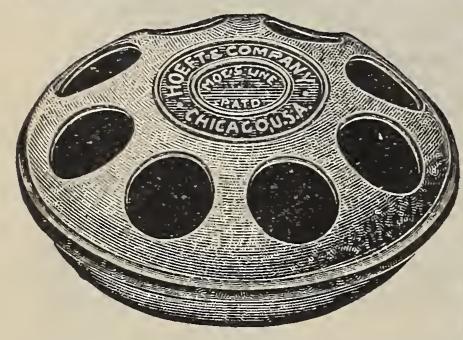

IM O F'S ROUND BA B Y C II I K IEDDSR-Insures pure food for the chicks. A great feed saver, as the chicks cannot get into it and contaminto it and contaminate feed. Small each; Irarge size, No. $12,35 \mathrm{c}$ each, postpaid. Not postpaid, No. 11, 15c

MOE'S DRY MASF HOPPER.The curved bottom of the Hopper keeps the feed within easy reach of the birds. The wire grid and the wires running from the flange prevent any chance of the fowls wasting the feed. The sloping cover prevents the birds from roosting on the hopper, and when covers are closed it is rat and mouse proof.

No. 35- $81 / 2$ ins. wide. Fach, $\$ 1.60$ postpaid. Not postpaid, $\$ 1.50$.

No. 36-12 ins. wide. Fach, \$2.10 postpaid. Not postpaid, $\$ 2.00$.

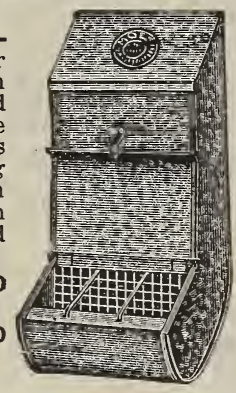

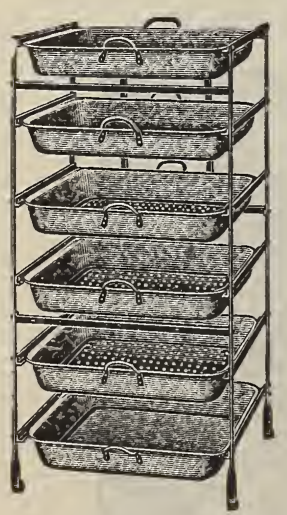

FUMPTY DUMPTY IOIDING I G G CRATES - A safe and convenient folding, shipping crate ing, shipping crate hard wood with wire rod through corners and card board division and fillers.

6-dozen egg size ...

12-dozen egg size

MOF'S OAT SPROUTER.Made entirely of metal. Strong and rigid. Provides the very necessary green feed at all seasons. Healthy chickens and more eggs. The frame is of steel, well braced and neatly painted. Has six heavy galvanized iron pans. Five of the pans have perforated bottoms to secure the proper drainage, and the bottom pan is solid to hold the drippings. Pans are interchangeable. Sectional frame can be quickly taken apart and stored in a small space. Total height of frame, $3 \mathrm{ft}$. Size of pans, $16 \times 18$ ins. Packed knocked down, one in a crate. Shipping weight, 25 pounds.

Price, each, postpaid, $\$ 6.50$; not postpaid, $\$ 6.00$.

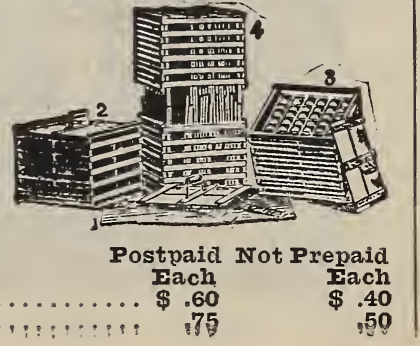

1-2-3 FFEDF-Made of galvanized iron, and so arranged as to have one, two, or three compartments. A very popular practical feeder. $\$ 1.50$ each, postpaid. Not postpaid, $\$ 1.35$ each.
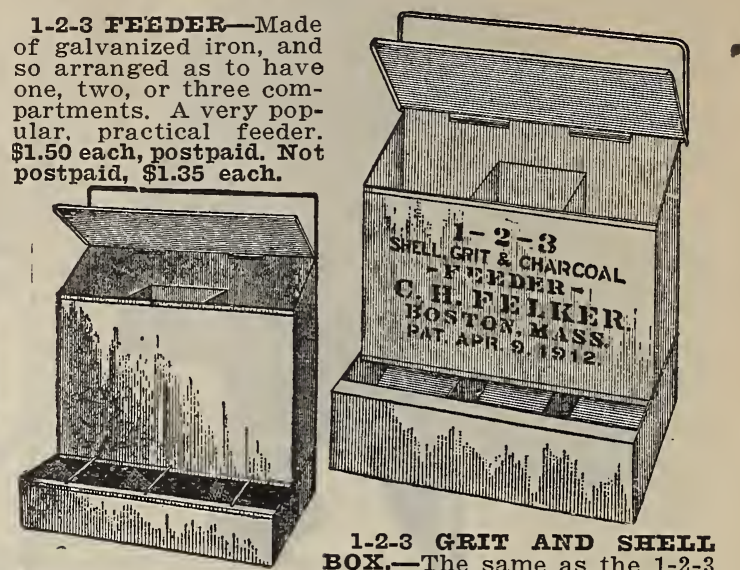

1-2-3 GRIT AND SHFIT feeder, but smaller in size, and especially adapted for feeding beef scrap, shells, charcoal or grit. $\$ 1.00$, postpaid. Not postpaid, 85c.
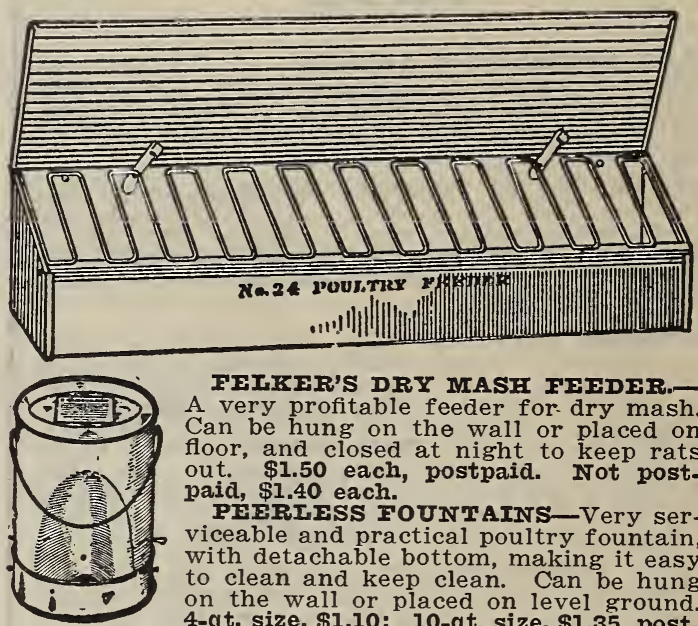

FIIKIR'S DRY MASA IFFDFR.A very profitable feeder for dry mash. Can be hung on the wall or placed on floor, and closed at night to keep rats out. $\$ 1.50$ each, postpaid. Not postpaid, $\$ 1.40$ each

PFERIESS FOUNTAINS-Very serviceable and practical poultry fountain, with detachable bottom, making it easy to clean and keep clean. Can be hung on the wall or placed on level ground. 4-qt. size, \$1.10; 10-qt. size, $\$ 1.35$, postpaid. Not postpaid, 4-qt. size, $\$ 1.00$; 10-qt, size, $\$ 1.25$.

C I A IM P I O I IFG BANDS.-Very neat, light, strong and durable. Easily and quickly put on, and guaranteed to stay. Numbers from one to one hundred. Adjustable in size. 15c per doz.; 50 for 50c; 100 for 80c, postpaid.

PFRFFCT POUTTRY MARKFR.-Makes a good clear cut, without mutilating the web. Fach 35c.

MOE'S IGG TrSTrR.-Made to fit any ordinary kitchen lamp; practical and accurate. $40 \mathrm{c}$ each, postpaid. Not postpaid, 35c each.

REFFFRS "MOR FGG" TABIFTS.-A scientifically prepared tablet dissolved in drinking water to increase production of eggs. Highly recommended by users. 50c per pkt., postpaid.

IATIP WICKS.-For No. "O" Incubator, 20c per dozen. Ior No. 1-2-3, 25c per dozen.

A "IITTIS PUTIAIM STOVמ." - Keeps poultry drinking water nice and warm during zero weather. Pays for itself in increased egg profiction. See page 39

INCUBATOR TIIR. MOMFTFRS. - Retested and certified. $\$ 1.00 \mathrm{each}$ postpaid.

BROODER THFRMOM. FTrRS. - Retested and certified. $75 \mathrm{c}$ each, post. paid.

IM O I'S IM A G A ZIN I FIIDFR-This feeder can be used either for grain or as a water fountain. It is self-feeding in either case well built, and insure: 70c each, postpaid. Ir ot postpaid, $60 \mathrm{c}$ each.

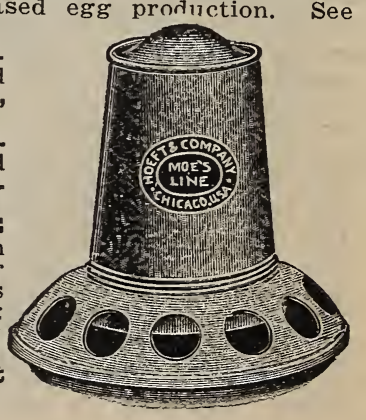




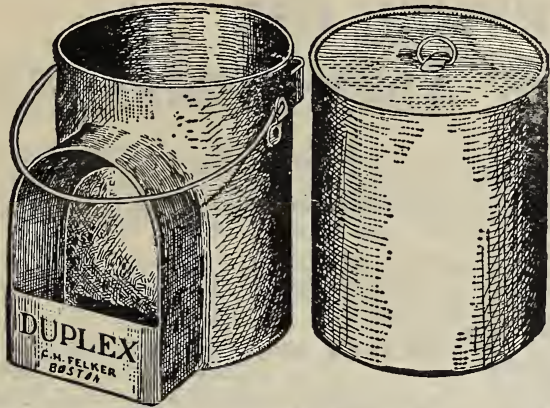

DUPIEX WAII FOUNTAIN-The latest and most practical sanitary poultry fountain on the market. This is a double fount, easy to fill, and keeps the water clean and pure. Made in two sizes. By mail postpaid, I-gal. size, $\$ 1.40$ each; 2-gal. size, $\$ 1.70$ each. Not prepaid, 1-gal. size, $\$ 1.25$ each; 2-gal. size, $\$ 1.50$ each.

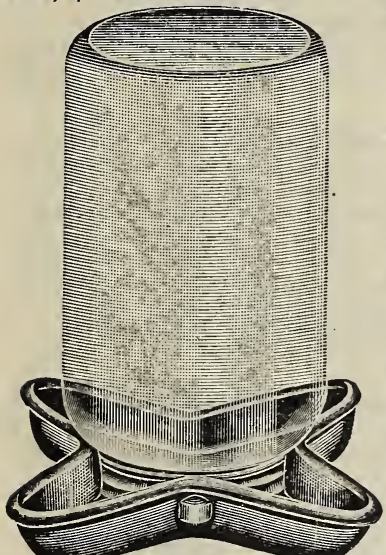

NO SIOP FOUNTAINS This is one of the best, c h e a p es t appliances used as a feeder or fountain. They are durable tin pans constructed to fit any mason fruit jar, and are used for water or food. V e ry convenient and practical. 20c each; 4 for $50 \mathrm{c}$, postpaid. Not postpaid, 15 c each; 5 for $50 \mathrm{c}$

MEDICATED NEST FGGS-A splendid nest egg with lice killing and disinfecting properties Should not be placed with set ting eggs. 60c per doz., post. paid. Not postpaid, 50c er dozen.

IIMTE NFST FGGSAn improvement on the China Nest Egg, as it does not' get so extremely cold in the winter. Per doz., 35c, postpaid. Not postpaid, 30c per dozen.

COIORED CFIIUIOID IEG BANDS. - Made in ring form; all sizes; easily adjusted. Not numbered. Colors: White, Yellow, Red, Green, Black, Cerise. Brown, and Pink. Per doz., 20c; 50 for 50c; 85c per 100, postpaid. Not postpaid, 15c per doz.; 25 for $25 \mathrm{c}$; $75 \mathrm{c}$ per 100.

\section{INTERNATIONAI}

\section{SAIITARY HOVIR.}

Can be used anywhere. Can be picked up and car ried around with ease, and is ready for use anywhere it may be dropped. This hover is so constructed as to provide a higher temperature at the outer edge, and prevents the chicks from crowding. Lamp can be removed without disturbing chicks. The International Sanitary Hover has met with marked approval with the leading and best known poultry raisers throughout the country. Price, complete, $\$ 15.00$.

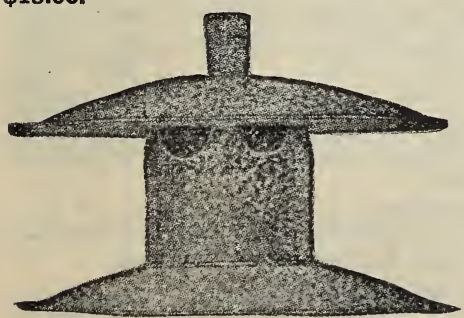

PUTNAM BROODER HEATER

This is used to heat a home$m$ a d e brooder, which will take the best of care of from 30 to 60 chicks. Instructions for making b rood er packed with every heater. A the brooder in an hour with saw and hammer. The materials need not cost over $25 \mathrm{c}$

The Putnam Brooder Heater holds one quart of oil and will burn 10 days without filling or trim ming; needs no other attention. The Putnam Brooder can be operated anywhere and in any climate. It is built on the principle of an open fireplace. It carries out the foul and draws in fresh air, providing continuous ventilation. Heat is radiated from above upon the backs of the chicks just as with the mother hen. The floor of the hover is even with the ground; the chicks have no inclines to learn and don't get lost and cold.

The Putnam Brooder Heater is made of brass and galvanized iron, and it is practically indestructible. Price of Putnam Brooder Heater, \$4.75.

Iilustrated circular on request.

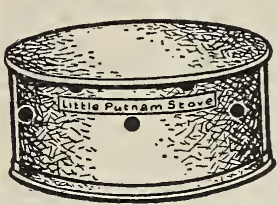

\section{IITTIF PUTNAM STOVP} FOR POUITRY FOUNTATNS

This little device will keep the water from freezing in zero weather. It holds $6 \mathrm{c}$ worth of oil and burns a month without filling or trimming. Fool-proof and fire-safe. Used under any can, crock or fountain.

A Little Putnam Stove is also used to heat a home-made oat sprouter. Plans for making sprouter packed with every stove. A 14-year-old boy can

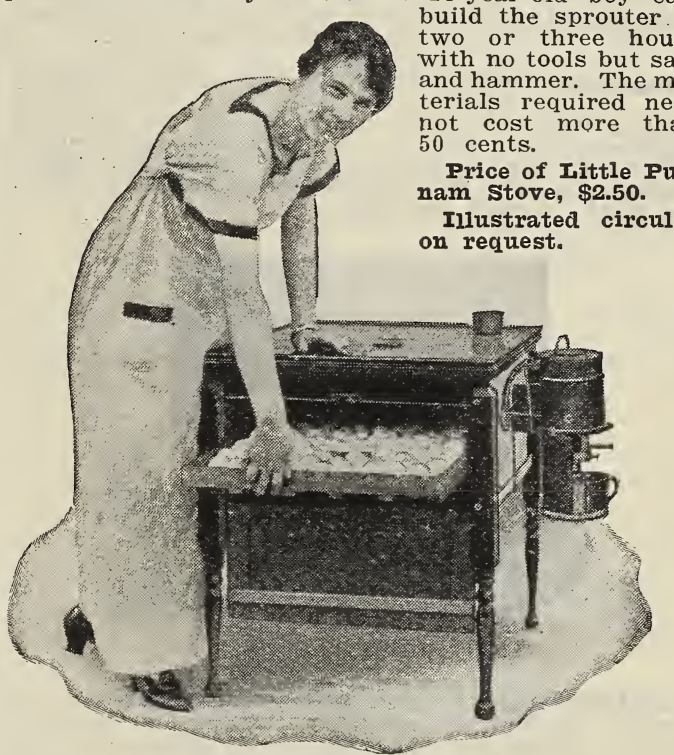

\section{QUEEN INCUBATORS}

Queen Incubators are famous the country over for big hatches of strong, healthy chicks that live and grow. The Queen is accurately regulated, keeping the temperature just right for the hatching chick. No hot and cold changes to weaken the chick's system. The Queen is properly insulatedtwo layers of wood and one of corrugated strawboard, with dead air space. This also helps to maintain an even temperature for the entire hatching period. Both Queen walls are built of genuine California Redwood, which is unusual in these days of imitation and cheap substitution.

Redwood does not absorb the odor from the hatching eggs. Cheaper woods, and pasteboard lining in iron and tin machines, retain the odors, to weaken and kill the hatching chick.

Sizes and Prices:

No. 1- 85-egg capacity $\ldots \ldots \ldots \ldots \ldots \ldots \ldots . \$ 27.50$

No. 2-135-egg capacity .............. 37.50

No. 3-180-egg capacity ............. 44.50

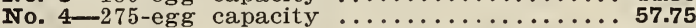

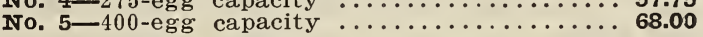

QUEEN STYIE $K$ INCUBATORS

No. 20-70-egg capacity ............ 16.50

No. 2I-130-egg capacity ................27.50

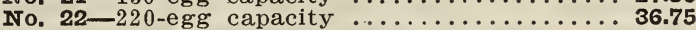

QUEFN BROODFR STOVES

No. $1-600$-chick capacity ............ 21.50 No. 2-1,200-chick capacity .............26.50

Ask for QUEmN Catalog Free. 


\section{SUCCESSFUL POULTRYMEN USE}

\section{PRATT'S POULTRY FEEDS AND REMEDIES}

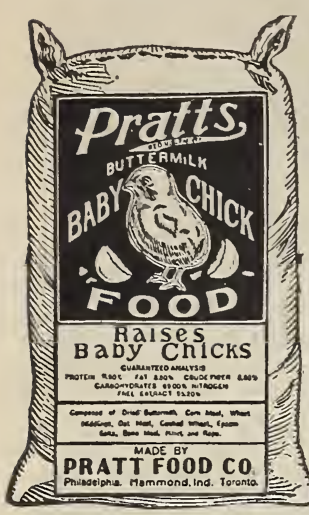

PRATT'S BABY CHICK FOOD, With Buttermilk. - A largely predigested baby food for baby chicks. Guaranteed to raise every livable chick, prevent leg weakness, white diarrhoea, and "pasting up." Using Pratts Baby Chick Food Using Pratts Baby Chick Food means Life Insurance for the baby chicks for the critical first three weeks period, at a teed to give the little fellows a splendid start which will prove the foundation for the prove the foundation for the development of strong, healthy pkg. 35c; 53/4-1b. pkg. 65c; 14-1b. bag, $\$ 1.25$; 25-1b. bag, \$2.25, postage prepaid. Not prepaid, $21 / 2-1 \mathrm{~b}$. pkg. 25c; 53/4= lib. pkg. 50c; 14-1b. bag, $\$ 1.00$; $25-1$ b. bag, $\$ 1.75 ; 50-1$ b. bag, $\$ 3.00$; 100-1b. bag, $\$ 5.25$.

PRATTS GROWING MASH, With Buttermilk. For growing youngsters. The bone, muscle, and feather builder. Start chicks on Pratts Growing Mash when they are two weeks old. Promotes rapid, Mash when they are two weeks old. Promotes rapid, postage prepaid. Not prepaid, 10-1b. bag 60c; 25-1b. bag $\$ 1.15$; $100-1 b$. bag $\$ 4.00$.

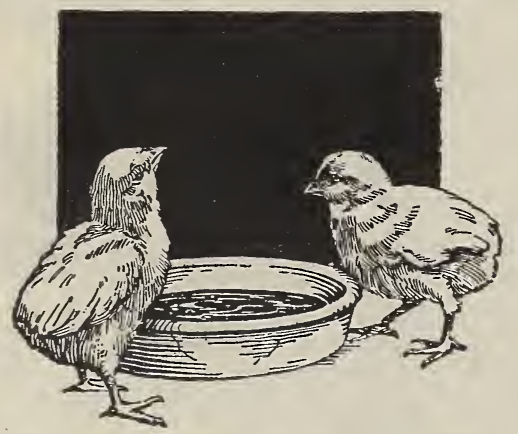

PRATTS CHICK-SIZR SCRATCH FEFD.-A recleaned combination of chick size grains for baby chicks. Should be used in connection with Pratts Buttermilk Baby Chick Food and Pratts Buttermilk Growing Mash. 10-1b. pkg. 75c; 25-1b. bag \$1.50, postage prepaid. Not prepaid, 10-1b. pkg. 60c; 25-1b. bag $\$ 1.25$; $100-1$ b. bag $\$ 4.25$.

PRATTS INTERIMPIATE SCRATCH FFFDNever in your life have you seen such a splendid scratch feed. Clean cut, uniform in size, attractive in variety and appearance, free from every particle of dust, hulls, chaff, weed seeds, or foreign materials, perfectly milled and mixed. Pratts intermediate Scratch Feed is the envy and despair of other feed makers and the delight of the chickens. 10-1b. pkg. 75c; 25-1b. pkg. \$1.50, postage prepaid. Not prepaid, 10-1b. pkg. 50c; 25-1b. pkg. \$1.00; 100-lb. bag $\$ 3.75$.

PRATTS IARGF SCRATCH FEDD-Gives such splendid results. Made only of the best of plump, sweet, well-seasoned grains-it is the very acme of quality and gives the maximum of results. 10-1b. bag 60c; 25-1b. bag $\$ 1.35$, postage prepaid. Not pre. paid, 10-1b. bag 50c; 25-1b. bag $\$ 1.00$; 100-1b. bag $\$ 3.50$.

PRATTS BUTTERIITK IAYING MASH-This remarkable mash is the standard by which others are judged. Not alone theoretically right but proven by practical test to be the greatest "egg producer" ever made. There is a good reason for every ingredient in this splendid mash. Pratts Buttermilk
Laying Mash produces more eggs at less cost per dozen and gives greatest profits. 10-1b. bag 75c; 25-1b. bag $\$ 1.50$, postage prepaid. Not prepaid, 10-1b. bag 50c; 25-1b. bag \$1.00; 100-1b. bag \$3.75.

PRATTS ROUP RFMIDY.Tablets or Powders. $30 \mathrm{c}$ and $55 \mathrm{c}$ per plg., postage prepaid. Not prepaid,

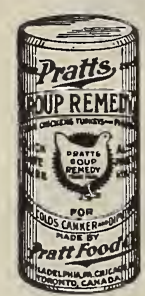
25c and 50c per plig.

PRATTS SPFCIAT COMPOUND. - A sure cure for chicken cholera. $30 \mathrm{c}$ and 55c per pkg. postage prepaid. Not pre. paid, $25 \mathrm{c}$ and $50 \mathrm{c}$ per pkg.

PRATTS GAPE REMPDY.-For gapes in baby chicks. $30 \mathrm{c}$ per pkg., postage prepaid. Not prepaid, 25c per pkg.

PRATTS WHITE DIARRHOFA TABIFTS.-A sure cure. $30 \mathrm{c}$ and $55 \mathrm{c}$ per pkg., postage prepaid. Not prepaid, $25 \mathrm{c}$ and $50 \mathrm{c}$ per pkg.

PRATTS SORE IEAD CFICKFN POX PRFPARATION.-40c per pkg., postage prepaid. Irot prepaid, 35c per pkg.

PRATIS POUITRY REGUIATOR-It builds up vitality, promotes sound digestion, sharpens appetite, thus helping to put birds into condition for heavy egg laving or winning blue ribbons. Given to breeding stock, it helps increase the fertility of eggs, strong in vitality, that will hatch chicks that will grow. Use it if you want big hatches of healthy chicks that will develop into husky pullets and cockerels. $30 \mathrm{c}, 60 \mathrm{c}$ and $\$ 1.75$ plkgs. postage prepaid. Not prepaid, $25 \mathrm{c}$ $50 \mathrm{c}$ and $\$ 1.40$ per pkg.

PRATTS ANIMAT RFGUIATOR -This is the original and pioneer stock regulator of America. Tested thoroughly for nearly half a century, its worth is known and recognized by stock owners the world over Always sold on a guarantee that it will satisfy you guarantee that it will satisfy you
or your money back. $30 \mathrm{c}$ and $60 \mathrm{c}$ pkgs., postage prepaid. Not prepaid, $25 \mathrm{c}$ and $50 \mathrm{c}$ per pkg.

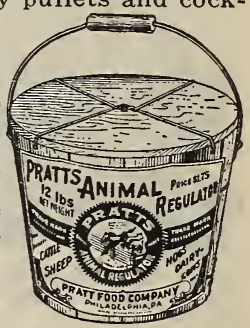

PRATTS SCAIX IFG OINTMIFI,-30c per pkg. postage prepaid. Not prepaid, 25c per plig.

PRATTS HFAD IICY OINTMENT FOR BABY CHICKS.-30c per pkg., postage prepaid. Not pre paid, 25c per pkg.

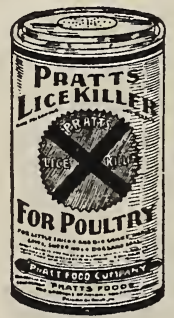

PRATTS POWDFR IICF KITIFR. -Unequalled for killing lice on birds of all ages. It also rids horses, cattle, hogs, dogs, and cats of lice. Can also be used for destroying insects and bugs on vines and plants. 15c, 30c and $60 \mathrm{c}$ per plkg. postage prepaid. Not prepaid, $10 \mathrm{c}, 25 \mathrm{c}$ and $50 \mathrm{c}$ per pkg.

P R A T S WORM POWDFR -A guaranteed worm exterminator for all cattle and stock. 60c per pkg., post. age prepaid. Not prepaid, $50 \mathrm{c}$ pkg.

PRATTS BTACK ITFAD RFIMET FOR TURIRFY- $\$ 1.10$ per pkg., postage prepaid. Not prepaid, $\$ 1.00$ per package.

PRATTS POUTTRY DISINFFCTANT AND ITOUID IICF KITTFR - Unequalled for spraying hen houses and other outbuildings. It is also used and recommended for household disinfectant purposes. Per pint can. $35 \mathrm{c}$; quart can, 55c; half-gallon can 90c; per gallon, \$1.50. Iiquids cannot be sent by mail.

PRATTS HOG TONIC.-A specially prepared tonic for hogs, guaranteed. $60 \mathrm{c}$ and $\$ 1.15$ per pkg., postage prepaid. Not prepaid, $50 \mathrm{c}$ and $\$ 1.00$ per pkg.

PRATTS COW rONIC. - Specially prepared for diseases of the cow. 60c per plkg; postage prepaid. Not prepaid, $50 \mathrm{c}$ per pkg: 


\section{Poultry and Stock Feeds}

AIFAIFA INTAI.-Fresh alfalfa hay ground fine for poultry. Can be used in a mash or alone as a substitute for green grass. 5-1b. pkg. 30c, postpaid. By express, 5-1b. pkg. 25c; 50-1b. pkg. \$1.50; 100-1b. bag, \$2.50.

IIFAT MIEAT, or BEEF SCRAP.-Pure dried ground beef, high in protein, and very essential as an egg producer in winter. 5-1b. pkg. $35 \mathrm{c}$, postpaid. By express, 5-1b. pkg. 25c; 50-1b. bag, \$2.00; 100 1b. bag, $\$ 3.75$.

POUITRY OYSTIR SHEIIS.-Recleaned and crushed shells for poultry. Ground fine for chicks, or medium for grown fowls. 4-1b. pkg. 25c; 15-1b. pkg. 50c, postpaid. By express, 4-1b. pkg. 10c; 15-1b. pkg. 25c; 100-1b. bag, \$1.00.

POUITRY CHARCOAI.-Aids digestion, promotes health and is indispensable in all poultry yards. Put up in two sizes: fine, for chicks, and medium, for fowls. 2-1b. pkg. 20c; 5-1b. pkg. 40c, postpaid. BJ express, 2-1b. pkg. 10c; 5-1b. pkg. 25c; 50-1b. bag, $\$ 1.50$.

HFMP SFED.-Largely used for pigeon and bird food. Ib. $15 \mathrm{c} ; 3$ lbs. $40 \mathrm{c}$; $10 \mathrm{lbs}$. $\$ 1.15$, postpaid. By express, 1b. 10c; 10 lbs. 90c; 100 lbs. $\$ 8.00$.

SUNIIOWER.-Rich food for grown fowls and parrots. Ib. $20 \mathrm{c} ; 10$ lbs. $\$ 1.50$, postpaid. By express, 1b. $15 \mathrm{c} ; 10$ lbs. $\$ 1.00$.

\section{UNICORN DAIRY RATION}

undoubtedly the best milk producing feed manufactured. If you are not a user of UNICORN, try a bag or two and convince yourself. Write for quotations.
ICAFIIR CORN.-Splendid food for all poultry. Especially recommended for pigeons. 5 lbs. $35 \mathrm{c}$, postpaid. BУ express, 5 lbs. 25c; 50 lbs. $\$ 2.00$.

OII CAKI MrzaI (F'lax Seed Meal, Old Process). -Used extensively for all kinds of stock, as a conditioner and tonic. Should be used in every stable. 4-1b. pkg. 25c, postpaid. By express, 4-1b. pkg. 20c; $100-1 \mathrm{~b}$. bag, $\$ 3.50$.

SAI VET,-This is the greatest worm destroyer known to the veterinary profession, and should be used by every one having a cow, horse, hog or sheep. It is not only a sure worm remedy but also a splendid conditioner and tonic. As exclusive agents for this territory, we offer Sal vet to our customers with an absolute guarantee with each package, or money refunded. 5-1b. pkg. 85c; $15-1 \mathrm{~b}$. pkg. $\$ 1.75$, postpaid. By express, 15-1b. pkg. \$1.50; 50-1b. keg, \$3.50; $100-1 b$. keg, $\$ 6.50$.

BIATCHFORD'S CAIF MLPA.-The perfect substitute for milk. Calves are successfully raised and fattened with this calf meal without milk. Recommended and used by all dairymen. 25-1b. bag, $\$ 2.00$, postpaid. By express, $25-1 \mathrm{~b}$. bag, $\$ 1.50$; $100-1 \mathrm{~b}$. bag, $\$ 5.50$.

BITTER IICK SAIT BRICK.-Should be kept constantly before horses and cattle. Each 35c, postpaid. By express, each 25c.

\section{PERFECTION BUTTER PACKAGE}

Strong, attractive, paraffined butter container, holding one pound. Makes the handling of butter a pleasure. Price, per doz. 50c; per hundred, \$3.50, postpaid.

\section{Vegetable Plants}

The supply and quantity of frost-proof cabbage plants is dependent on the severity of the winter, and price is regulated accordingly. From present outlook prices given below will rule, but should conditions improve we will give our customers the benefit of the lower price at time of order.

CABBAGE PIANTS.-Early varieties ready February, March, April. Late varieties in June and July. Early varieties for fall planting ready October and November. Per 100, 40c; per 1,000, $\$ 2.25$, postage prepaid. By express, $\$ 1.75$ per 1,000 , f. 0 . b. Petersburg.

TOMATO PIANTS.-Ready April, May, June and July. Transplanted and hardened plants, $30 \mathrm{c}$ per doz; $\$ 2.50$ per 100 , postpaid. Plants in cold frames, $75 \mathrm{c}$ per 100; $\$ 3.50$ per 1,000. By express, f. o. b. Peters. burg.

EGG PIANTS.-Ready May and June. Hardened and transplanted. 35c per cloz.; $\$ 2.50$ per 100, post. paid.

PEPPER PLANTS.-Ready May and June. Hardened and transplanted plants. 30c per doz. Cold Irame plants, 20c per doz.; $\$ 1.25$ per 100, postpaid.

SWEET POTATO PIANTS.-Ready May and June. Write for prices.

RHUBARB ROOTS.-Strong, healthy roots. 15c each; $\$ 1.50$ per doz., postpaid.

HORSFRADISH ROOTS.-25c per doz.; $\$ 1.00$ per 100.

\section{BIRD SEED}

SPECIAI MIXED.-Per 1b. 15a; $10 \mathrm{lbs}$. \$1.25. PIAIN CANARX SEED.-Per 1b. 15c; $10 \mathrm{lbs} . \$ 1.00$

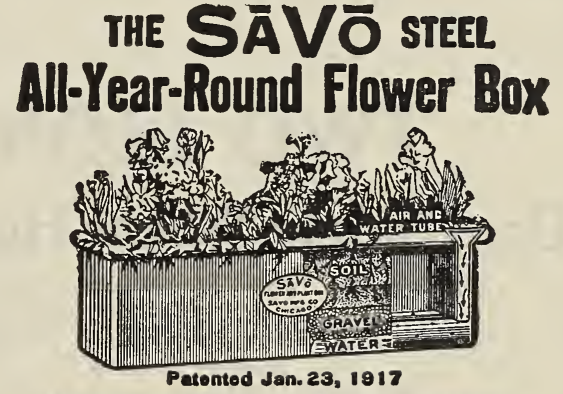

Solf-Watering and Sub-Irrigating

TOR WINDOWS, PORCHES, SUN PARLORS, ETC. Perfect Air Circulation and Drainage. Ieak-Proof and Rust-Proof.

MOST EFTICIFNT, DURABIE, ARTISTIC. Six Sizes. Beautifully Finished.

Fill with water only once a week. Move Savo Boxes indoors or out and you can have beautiful Flowers and Plants continually for many years.

\section{AN AII-YEAR-ROUND GARDEN}

Prices of Savo Steel All-Year Flower Boxes

Each.

Mrodel A-8 in. high, $9 \frac{1}{2}$ in. wide, 23 in. long...\$3.00 Model B-8 in. high, $9 \frac{1}{2}$ in. wide, 29 in. long.. 4.00 Model C-S in. high, $9 \frac{1 / 2}{2}$ in. wide, 35 in. long.. 4.50 Model $\mathbf{E}-8$ in. high, 12 in. wide, 12 in. long.. 3.00 Model $F-12$ in. high, 12 in. wide, 12 in. long. . 3.50 Model G-Round style box, 12 inches in diameter and with stand is $281 / 2$ inches high. Very attractive for ferns, etc. Complete with stand...\$6.00 


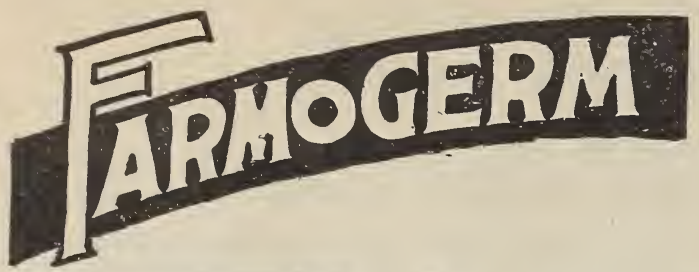

\section{A SEED and Soil INNOCULANT}

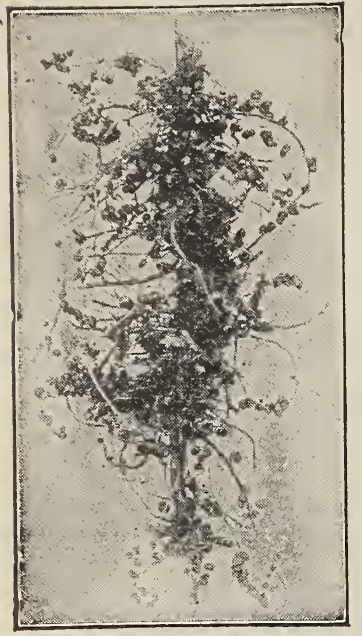

Roots like this mean

bigger yields,

better soil.

\section{That Increases Crop Production and Greatly Improves the Soil}

Soil and crop experts agree that for best growth, and to put atmospheric nitrogen in the soil, it will pay all farmers to inoculate all legumes, even where they are at present successfully grown. The cost is trivial when compared with the profit it will bring you. Legumes are clovers, peas and beans, alfalfa, soy beans, vetches, and other plants that grow their seeds in a pod. Their roots are the home of bacteria that draw fertility-building nitrogen from the air and store it in swellings on the roots, called nodules. These nodules not only feed nitrogen to the crop they are on, but rot away in the ground and supply valuable nitrogen to the soil for future bumper crops of corn, wheat, cotton, oats, fruits, etc.

\section{Economical-Easy to Use}

The 1-A size bottle will inoculate: Clovers, 15 lbs.; Alfalfa, 20 lbs.; Canada Field Peas, 100 lbs.; Vetch, 60 lbs.; Soy Beans, 75 lbs.; other sizes in relative proportion. Place seed in a pile, fill bottle with water, add a little sugar, shake and moisten seeds; when dry, plant in usual way. This is infinitely easier, safer and better than the old laborious soil transfer method.

We have a special composite culture for garden peas, beans and sweet peas; ask for No. 5, $50 \mathrm{cts.}$, and you will insure large, luscious peas and beans, and abundant sweet pea blossoms of wonderful coloring.

When ordering, be sure to specify the kind of seed you wish to inoculate. Prices: 1=acre size, $\$ 1.00 ; 3=a c r e, \$ 2.50 ; \quad 12=a c r e, \$ 9.00$. Full directions accompany each bottle. We recommend that you use FARMOGERM.

\section{TWO IRON AGE SPECIALS}

\section{Gem Single Wheel Hoe}

Here is a favorite tool. It is light and compact. Can be used for any kind of cultivation, and the price is low. Tools furnished consist of Cultivator Teeth, two sizes of Scuffle Hoe, and a pair Plows. We think this is undoubtedly the easiest wheel hoe to operate in existence; requires less strength than any other make, and will do better work. Price, complete, $\$ \mathbf{8 . 0 0}$.

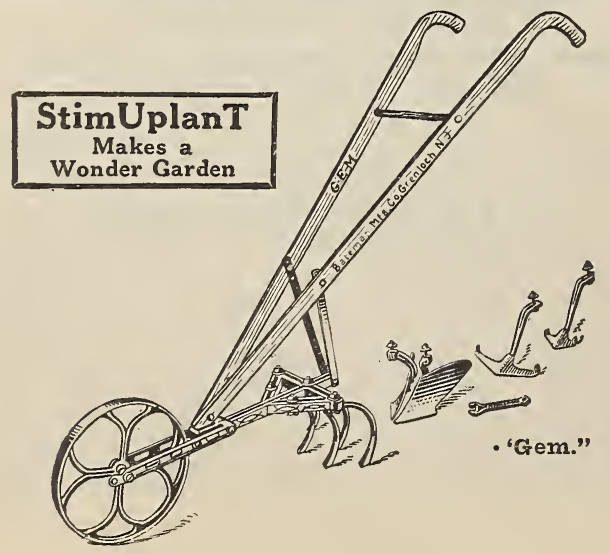

\section{Hill and Drill Seeder}

No. 316

Here is an important tool built especially for those who do not care for a combined tool, but desire separate machines for each purpose. With many and repeated sowings, a man must have a tool that is always ready for immediate service. The No. 316 will sow either in continuous rows or deeply in hills, $4,6,8,12$, or 24 inches apart. The change from hill to drill seeder takes only a moment. The operator has the satisfaction of watching the seed deposited in the furrow. It will sow successfully any variety of vegetable seed, as well as cow peas and beans. The tire furnished on this machine is $13 / 4$ inches widehalf an inch wider than can be used upon the combined double and single wheel machine. This keeps the wheel from sinking into the soft earth, and makes it easy to push.

พNo. 316

Price, $\$ 15.00$. 


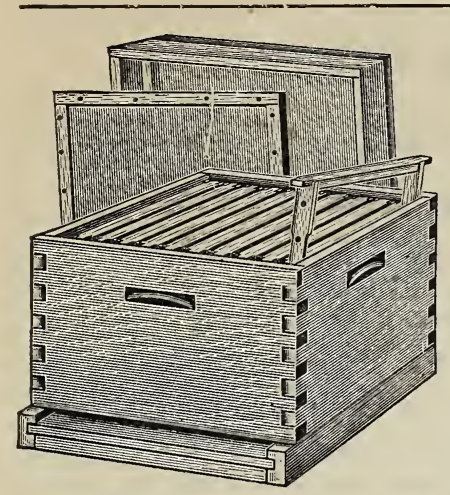

\section{Standard Dove-Tailed Hives}

5 10=fr. 1=story Hives, K. D........\$14.50

110 =fr. 1=story Hive, K. D.......... 3.50

$110=$ fr. 1=story Hive, N. \& P. . . . . . 5.25

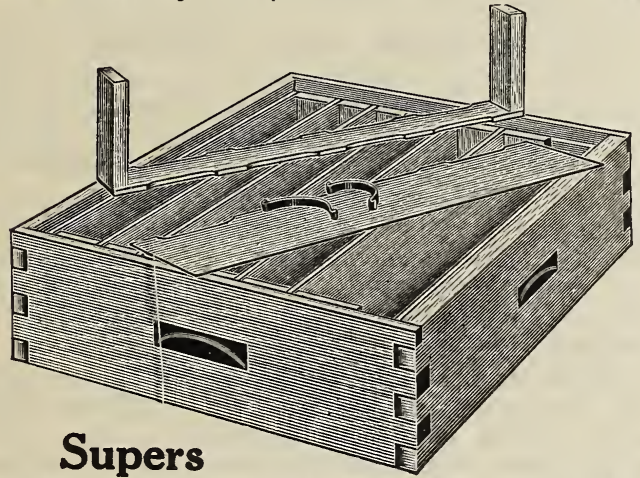

5 10=fr. Comb Honey Supers, K. D. . . . \$5.25

$110=$ fr. Comb Honey Supers, K. D.... . . 1.35

1 10=fr. Comb Honey Supers, N. \& P..... 2.90

\section{Honey Sections}

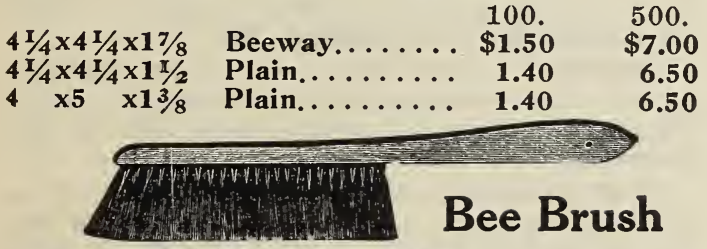

BRISTLE BEE BRUSH. Each......... .30

Postage prepaid ............. .35

\section{Lewis 4-Way Bee Escapes}
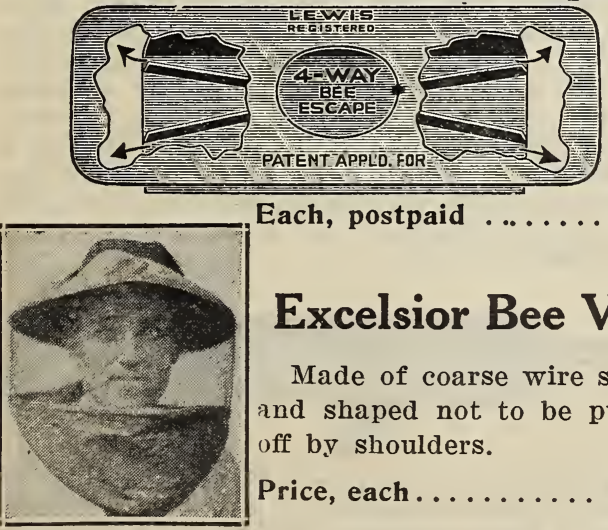

Each, postpaid

$18 \mathrm{c}$

\section{Excelsior Bee Veil}

Made of coarse wire screen and shaped not to be pushed off by shoulders.

Price, each .

$\$ 1.25$

\section{HIVES AND BEE SUPPLIES}

Our Bee supplies are strictly "Lewis Quality"; no seconds, no

\section{Hives \\ Hives}

in stock, within two days' notice.

are made of clear white pine, are "standard" in dimenwith regular (see illustration) or metal covers and self-spacing Hoffman frames, reversible bottom boards. All parts fit perfectly and are interchangeable.

\section{Dadant Wired Foundations}

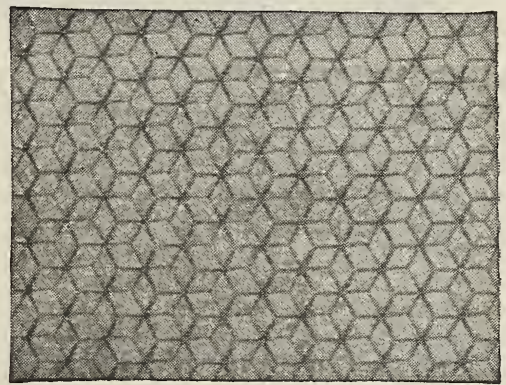

You can get the famous Dadant wired foundation, made without the use of acids, guaranteed perfect in every sheet, every pound, every ton.

Vertically Wired Medium Brood Foundation, 81/8 $\mathrm{x} 16 \mathrm{3} / 4$. $1 \mathrm{lb}$. at $83 \mathrm{c}$, mail wgt. $2 \mathrm{lbs}$; $25=1 \mathrm{~b}$. box at $\$ 19.00$.

Vertically Wired Light Brood Foundation, $81 / 8 \mathrm{x}$ $16 \frac{3}{4}$. 1 lb. at $86 \mathrm{c}$, mail wgt. 2 lbs.; $25=1 \mathrm{~b}$. box at $\$ 20.25$.

Thin Super Foundation, $37 / 8 \times 16 \frac{1}{2}$. 1 lb. at $88 \mathrm{c}$, mail wgt. 2 lbs.; $25=1$ b. box at $\$ 20.25$.

Extra Thin Super, $37 / 8 \times 161 / 2$. $1 \mathrm{lb}$. at $90 \mathrm{c}$, mail wgt. 2 lbs.; $25=1 b$. box at $\$ 20.75$.

Unwired Brood Foundation, $3 c$ per pound less than above prices.

Write for prices on other sizes, brood and supers.

\section{Steel Hive Tools}

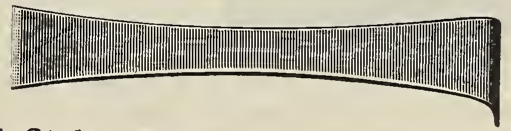

7=inch Style. Each.............\$.50

10 =inch Style. Each................ .6. 65

By mail postpaid, $60 \mathrm{c}$ and $75 \mathrm{c}$.

\section{Tin Smokers}

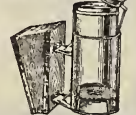

Woodman's Bingham Bee Smokers Best on the market.

Little Wonder, 3-inch. Each.........\$.85

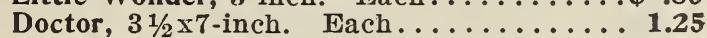

Smoke Engine, 4-inch. Each......... 1.50

Big Smoke, $4 \times 10$-inch. Each . . . . . . . . 1.75

If by mail add $10 \mathrm{c}$ to each smoker for postage.

Write us for complete Bee Supply Catalog. 


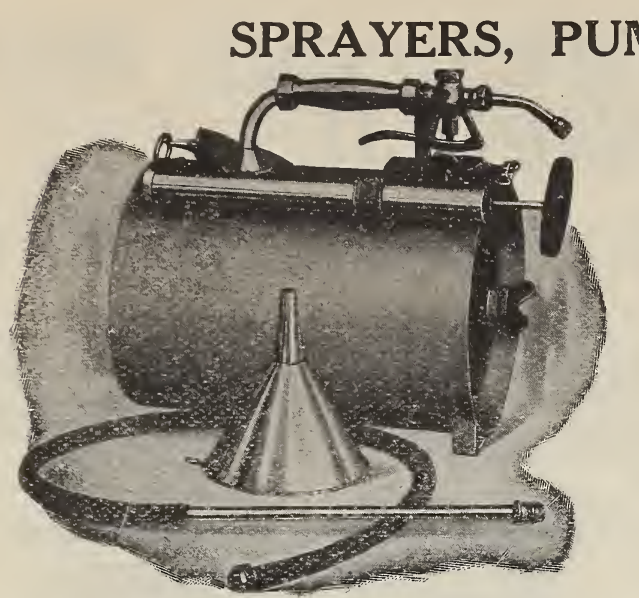

LOWELL FOUNTAIN SPRAYER. - This is one of the best compressed air spray pumps manufactured, and we not only recommend, but also guarantee it in every way. It has no intricate parts to get out of order. The spray material does not come in contact with the pump; the tank is thoroughly tested to stand the highest pressure, and will drain perfectly with one charge. We especially recommend this pump for spraying potatoes, cabbage, etc. Price complete, with spray crook nozzle, $3 \mathrm{ft}$. hose and $1 \mathrm{ft}$. long spraying nozzle, funnels for filling and shoulder strine \$6 mo.

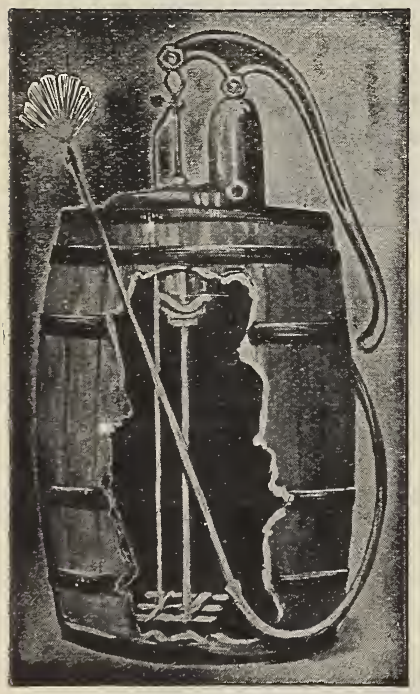

\section{OUR PERFECT BARREL SPRAY PUMP.}

This reliable pump is equipped with a seamless brass cylinder, b r a s s rod, brass plunger a $n d$ brass screw spout; it has a large air chamber and is a pump of great force and power. It has a suction $\mathrm{p}$ i $\mathrm{p} \theta$ and strainer, and churn dash agitator. This machine gives a full stream, fine $\mathrm{m}$ is $\mathrm{t}$, medium and coarse spray, as desired, and is unexcelled in its fine $\mathrm{w}$ o $\mathrm{rk}$ of s p ra y ing trees, shrubs, vines, etc. Every farmer, aairyman, poultryman and fruit grower should have one of these pumps on his premises, as it can also be used to such great advantage in whitewashing and disinfecting stables, barns, poultry houses, and in washing windows, vehicles, etc. Price complete, with 5 feet heavy hose and 10 feet extension rod, without the barrel, $\$ 20.00$.

NIAGARA HAND DUST GUN; A PACKAGE OF NIAGARA ALL: IN=ONE MIXTURE; N I A G A R A GARDEN GUIDE.-All packed together in a carton ready to go home and put into instant use. A quick,

sure and convenient way to relieve yourself of all worries over destruction to vegetables, flowers, shrubbery, house plants, etc., caused by in-

\section{AND DEVICES}

Whether you have one or a hundred"Spray Your Trees"

IF you do not know how or when to spray, write us for information, which will be gladly given.

\section{YOU WILL THANK US}

"THE S T A N D A R D" WHITEWASHING PUMP.-A simple but effective pump for whitewashing barns, stables, outhouses, etc. Easy to operate; works in any bucket, tub or barrel; also sprays trees, shrubs, etc., to perfection. Throws stream three stories high. Pays for itself in one day's work. Guaranteed to give satisfaction. Price, \$5.00.

LOWELL GLASS TANK SPRAYER. - The best hand sprayer made-durable, easy to handle and operate. Tank is a quart Mason fruit jar, which can be readily replaced if broken. Sprays a fine mist. Price, each 75c, or $90 \mathrm{c}$ postpaid.

LOWELL IDEAL SPRAYER.-Extra strong, substantially constructed, compact and handy sprayer. The cone passes through the solution tank and is thoroughly soldered thereto, giving great strength and rigidity. $60 \mathrm{c}$ postpaid. Not postpaid, $50 \mathrm{c}$ each.

LOWELL CONTINUOUS SPRAYER. - Operates continuously on both the up and down stroke of the plunger and throws a fine, misty spray. Will handle all solutions, insecticides and disinfectants. Used in the greenhouse, poultry house, the home, for shrubs and for applying automobile polish. Construction is such as permits its being operated at any angle and will not tip over when filling. All parts readily accessible for cleaning should occasion require. Each, $90 \mathrm{c}$, postpaid. Not postpaid, $75 \mathrm{c}$.

"MIDGET" SPRAYER. - A small, durable, hand sprayer recommended for household use for disinfecting purposes. Price, each $35 \mathrm{c}$, or $50 \mathrm{c}$ postpaid.

THE CYCLONE SEED SOWER.-This is a fine little Seeder at a moderate price. Sows any kind of seed evenly, as well as fertilizer, bone and ashes, and pays for itself in a very short time. Price, each $\$ \mathbf{2 . 2 5}$, or $\$ 2.50$ postpaid.

LITTLE GIANT DUSTER.-Distributes any dry powder, like Dry Arsenate of Lead, Slug Shot and Paris Green, to perfection. Keeps the poison at a safe distance from the operator, and will dust potato plants as fast as the operator can walk, two rows at a time. One of the best appliances for tobacco growers. By turning a handle a fan is rapidly revolved, distributing the insecticides uniformly on two rows at once, and to all parts of the plant and on both sides of the leaf. Price, $\$ 11.00$.

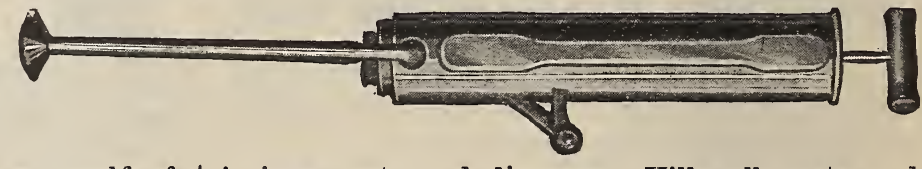

jurious pests and diseases. Kills all pests and diseases without the use of water. No mussy chemicals. Price, complete, $\$ 3.50 ; \$ 3.75$ postpaid. 


\section{SPRAYING GUIDE}

This condensed spraying calendar has been carefully prepared and will be found very valuable to fruit growers as ${ }^{\top} i t$ sh ows at a glance how to spray intelligently for the various insect pests and fungus diseases to which fruit trees are subjected.

\begin{tabular}{|c|c|c|c|}
\hline $\begin{array}{c}\text { KIND OF } \\
\text { FRUIT }\end{array}$ & $\underset{\text { PEST }}{\text { KIND OF }}$ & $\underset{\text { USE }}{\text { WHAT TO }}$ & *DILUTION \\
\hline \multirow{6}{*}{ APPLE } & San Jose Scale... & Dry lime sulphur.... & 25 to $30 \mathrm{lbs}$. \\
\hline & Codling moth... & Dry arsenate of lead. & 2 to $3 \mathrm{lbs} . . .$. \\
\hline & Cankerworm.... & Dry arsenate of lead. & 2 to $4 \mathrm{lbs} .$. \\
\hline & Bitter-rot....... & Dry bordeaux...... & $18 \mathrm{lbs} . . . \ldots$ \\
\hline & Blotch... & $\begin{array}{l}\text { Dry lime sulphur.... } \\
\text { Dry bordeaux....... }\end{array}$ & $\begin{array}{l}6 \text { lbs.......... } \\
14 \text { to } 18 \text { ibs. }\end{array}$ \\
\hline & Scab........... & Dry lime and sulphur & 6 to $8 \mathrm{lbs} .$. \\
\hline \multirow{5}{*}{ PEACH } & Peach twig borer & Dry lime sulphur... & $25 \mathrm{lbs} . . . .$. \\
\hline & Curculio..... & $\begin{array}{l}\text { Dry arsenate of lead } \\
\text { and lime............ }\end{array}$ & $\begin{array}{l}2 \text { to } 3 \text { lbs... } \\
6 \text { lbs. }\end{array}$ \\
\hline & Brown rot...... & $\begin{array}{l}\text { Self-boiled lime and } \\
\text { sulphur............ }\end{array}$ & $16 \mathrm{lbs}$. of each \\
\hline & Scab........... & $\begin{array}{l}\text { Self-boiled lime and } \\
\text { sulphur............. }\end{array}$ & $16 \mathrm{lbs}$. of each \\
\hline & Leaf curl........ & Dry lime sulphur.... & 25 to $30 \mathrm{lbs}$. \\
\hline \multirow{4}{*}{ PEAR } & Slug............ & Dry arsenate of lead. & $2 \mathrm{lbs} . . . . .$. \\
\hline & Pear psylla...... & Dry lime sulphur.... & 25 to $30 \mathrm{lbs}$. \\
\hline & $\begin{array}{l}\text { Pear leaf blister } \\
\text { mite }\end{array}$ & Dry lime sulphur.... & 25 to $30 \mathrm{lbs}$. \\
\hline & Scab........... & $\begin{array}{l}\text { Dry lime sulphur.... } \\
\text { Dry bordeaux. }\end{array}$ & $\begin{array}{l}6 \text { to } 8 \text { lbs... } \\
18 \text { lbs. }\end{array}$ \\
\hline \multirow{3}{*}{ PLUM } & Curculio......... & Dry arsenate of lead. & $2 \mathrm{lbs} \ldots \ldots$ \\
\hline & Brown Rot...... & Dry lime sulphur.... & 2 to 3 Ibs... \\
\hline & Leaf Spot....... & Dry lime sulphur.... & 2 to $3 \mathrm{lbs} . .$. \\
\hline \multirow{3}{*}{ CHERRY } & Cherry Slug.... & Dry arsenate of lead. & 2 to $3 \mathrm{lbs} . .$. \\
\hline & Brown Rot...... & Dry lime sulphur.... & 2 to $3 \mathrm{lbs} . .$. \\
\hline & Curculio......... & Dry arsenate of lead. & 2 to $3 \mathrm{lbs} . .$. \\
\hline \multirow{3}{*}{ GRAPE } & Rose Chafer..... & $\begin{array}{l}\text { Dry arsenate of lead } \\
\text { and molasses........ }\end{array}$ & 4 lbs.; 2 gal. \\
\hline & $\begin{array}{l}\text { Grape Berry } \\
\text { Moth........ }\end{array}$ & Dry arsenate of lead. & $3 \mathrm{lbs} . . . . .$. \\
\hline & Black Rot.. & Dry Bordeaux....... & 14 to 18 lbs. \\
\hline
\end{tabular}

(1) Means first WHEN TO SPRAY

In fall after leaves drop or in

drop or in srping when trees are dormant.

(1) At fall of the blossoms before the calyx closes. (2) Three weeks after fall of blossoms. (3) Ten weeks after fall of blossoms. (4) Fourteen weeks after fall of blossoms: (5) Seventeen weeks after fall of blossoms.

(1) Just before blossoms in cluster bud. (2) At fall of blossoms. Spray about the middle of June and keep fruit coated the resr of the season.

(1) Three weeks after fall of blossoms. (2) Five weeks after fall blossoms.

(1) Just before blossoms in cluster bud. (2) At fall of blossoms. (3) Within a week or ten days later. (4) Latter part of July if weather is cool and wet.

Just after buds begin to swell.

(1) When first shucks are pushing off. (2) Again when all shucks are off. (3) Three or four weeks after fall of blossoms.

(1) When all shucks are off. (2) Three or four weeks after fall of blossoms. (3) Four weeks before fruit is ripe. Should weather be damp and warm near ripening time keep fruit well coated with spray.

Spraying for brown rot controls scab.

Either in fall after leaves drop or in spring before buds swell.

When slugs appear.

When cluster buds are separating at tips.

In fall after leaves drop or in the spring before buds burst.

(1) Just before bloom, cluster-bud. (2) At fall of blossoms. (3) Two weeks later.

(1) Just before blossom buds open. (2) At fall of blossoms. (3) A week later.

(1) just before buds open. (2) Immediately after blossoms fall. (3) Ten days to two weeks later. If season is wet, spray every two weeks until month before picking time.

(1) Ten days after fall of blossoms. (2) Three weeks later. (3) Six weeks after fall of blossoms.

When slugs appear.

(1) Just before the blossoms. (2) At fall of blossoms. (3) A week to 10 days later. (4) When fruit begins to color.

(1) At fall of blossoms. (2) A week to ten days later.

At first appearance of beetles and one week later if beetles are still present.

(1) Just before fruit sets. (2) About ten days later. (3) Mid-July.

(1) When second or third leaf is showing. (2) Before the blossoms open. (3) After fall of blossoms. (4) About ten days to two weeks later. (5) Again in ten to fourteen days.

*All dilutions to be made on the following basis to the 100 gallons of spray.

\section{Approximate Quantities of Diluted Spray Solution Required for Thorough Spraying}

The quantity will vary, of course, according to the size of the tree and whether or not the tree is dormant, in blossom or in full leaf.

\begin{tabular}{|c|c|c|c|c|}
\hline AGE & PEACH TREES & PLUM TREES & APPLE TREES & PEAR TREES \\
\hline 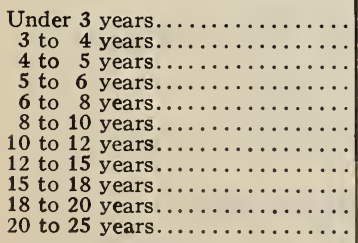 & 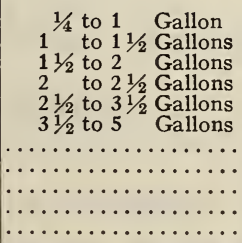 & 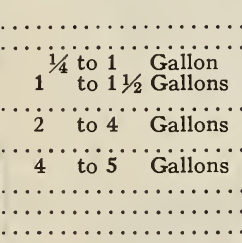 & 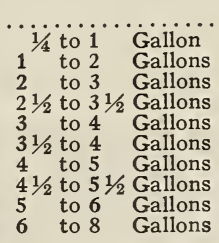 & $\begin{array}{l}1 / 4 \text { to } 1 / 2 \text { Gallon } \\
1 / 2 \text { to } 11 / 2 \text { Gallon } \\
11 / 2 \text { to } 1 \frac{1}{2} \text { Gallons } \\
21 \text { to } 2 \text { Gallons } \\
21 / 2 \text { to } 21 / 2 \text { Gallons } \\
3 \text { to } 31 / 2 \text { Gallons } \\
31 / 2 \text { to } 51 / 2 \text { Gallons } \\
5 \text { to } 8 \text { Gallons } \\
\begin{array}{ll}1 & \text { Gallons }\end{array}\end{array}$ \\
\hline
\end{tabular}




\section{$\because$

We name below a few of our popular and well known brands of high grade Guanos. As prices on fertilizers ana fertilizer materials are apt to change at any time, we quote subject to change without notice. We shall, however, endeavor not to advance any price as given below, and will give our customers the benefit of any decline which may have occurred in the market up to time that the order arrives. We shall be glad to hear from our customers with a list of their requirements of fertilizers and materials and will use our best efforts to name especially attractive prices in accordance with quantities desired. Prices on all fertilizers are quoted f. o. b. Petersburg. Write for delivered prices to your shipping point.

\section{THE PRICES ARE STRICTLY NET CASH WITH ORDER.}

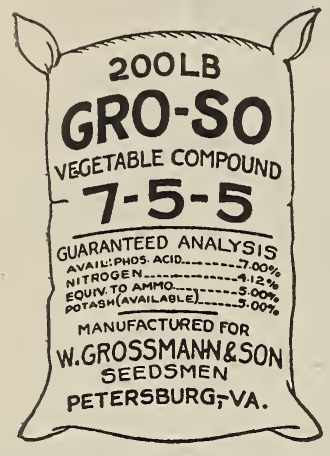

GRO $=S O$

VEGETABLE

COMPOUND

Guaranteed Analysis: Available Phosphoric Acid 7 to $8 \%$; Ammonia 5 to $6 \%$; Available Potash 5 to $6 \%$

We are having this brand especially manufactured for our truckers, to be used in the growing of their vegetable crops. Material used is of the highest quality without any effort to reduce cost, and we recommend $t h$ is brand with the satisfaction of knowing that it is the best that can be used. Especially recommended for all crops growing out of the ground, which require rapid and continuous growth

Price, per $200 \mathrm{lb}$. bag, $\$ 4.25$; per ton, $\$ 38.00$.

\section{SPECIAL TRUCK GUANO}

Analysis: Acid Phosphate, 8\%; Ammonia, 5\%; Potash, $8 \%$.

A very highly ammoniated truck guano extensively used throughout the trucking section of Eastern Virginia. A wonderful promoter of growth.

Price, per 200 lb. bag, $\$ 4.50$; per ton, $\$ 40.00$.

\section{DIXIE COTTON GROWER}

Analysis: Available Phosphoric Acid, 8\% Ammonia, 4\%; Potash, $4 \%$.

A specially prepared fertilizer for cotton. Promotes growth and even maturity of the cotton plant. A great favorite with cotton farmers who know.

Price, per 200 lb. bag, $\$ 3.75$; per ton, $\$ 35.00$.

\section{STANDARD COTTON GUANO}

\section{Analysis: Available Phosphoric Acid, 8\%;} Ammonia, 3\%; Potash, 3\%.

The most generally used cotton guano in this section. A guano of merit, and used extensively for a number of other crops.

Price, per $200 \mathrm{lb}$. bag, $\$ 3.50$; per ton, $\$ 33.00$.

\section{B. PEANUT GROWER}

Analysis: Available Phosphoric Acid, 8\% Ammonia, 11/4\%; Potash, $4 \%$.

This is a great favorite for corn and peanuts, and is extensively used in this section. A number of our large peanut growers are using this brand on lands deficient in humus, and are getting good crops with a minimum of pops.

Price, per 200 lb. bag, \$2.60; per ton, $\$ 25.00$.

\section{HIGH=GRADE PULVERIZED} SHEEP MANURE

We recommend highly this finely ground pulverized sheep manure for all crops; being a natural fertilizer it does not burn or sour the land. It is quick in action and effective in results. Recommended especially to our truckers for the early vegetable crops, as also for grasses, grains, and lawns.

Price, per $100 \mathrm{Ib}$. bag, $\$ 2.50$; per ton, $\$ 40.00$.

GRO=SO SPECIAL POTATO GROWER

Guaranteed Analysis: Available Phosphoric Acid 8 to 9\%; Ammonia 4 to 5\%; Available Potash 4 to $5 \%$

This is our special preparation for growing potatoes to perfection. In the manufacture of this high grade guano we are using only the very best material in such proportions as to insure the maximum crops under general conditions. Being compounded under our personal supervision, we confidently recommend this brand to our potato growers. We also recommend this brand for all root crops.

Price, per 200 Ib. bag, $\$ 3.75$; per ton, $\$ 35.00$.

\section{BRIGHT LEAF TOBACCO GUANO}

Analysis: Arailable Phosphoric Acid, 8\%; Ammonia, 3\%; Potash, 3\%.

This splendid guano is the leader in our bright tobacco section. It is known to produce a crop with the necessary weight, yet retaining finest of texture in the leaf.

Price, per 200 Ib. bag, $\$ 3.50$; per ton, $\$ 33.00$.

\section{OSCEOLA TOBACCO GUANO}

Analysis: Available Phosphoric Acid, 8\%; Ammonia, 3\%; Potash, 3\%.

A specially prepared guano for the growing of dark tobacco. This brand is too well known in this section to need description, and will surely oring results.

Price, per $200 \mathrm{lb}$. bag, $\$ 3.50$; per ton, $\$ 33.00$.

\section{CHAMPION CORN GUANO}

Analysis: Available Phosphoric Acid, $10 \%$ Ammonia, 11/4\%; Potash, $1 \%$.

Manufactured as a special corn guano, also largely used by peanut growers, and for grains and grasses. A good, medium priced guano for general use.

Price, per 200 Ib. bag, $\$ 2.50$; per ton, $\$ 24.00$.

\section{LAND PLASTER Per ton, $\$ 14.00$.}

\section{NITRATE OF SODA}

Per 200 1b. bag, $\$ 7.00$; per ton, $\$ 65.00$.

$16 \%$ ACID PHOSPHATE

Per 200 1b. bag, \$1.75; per ton, $\$ 16.00$.

\section{GERMAN KAINIT}

Per 200 1b. bag, \$1.75; per ton, $\$ 16.00$

PURE RAW BONE MEAL

Per $200 \mathrm{lb}$. bag, $\$ 4.75$; per ton, $\$ 46.00$. 


\section{Vegetable and Flower Collections}

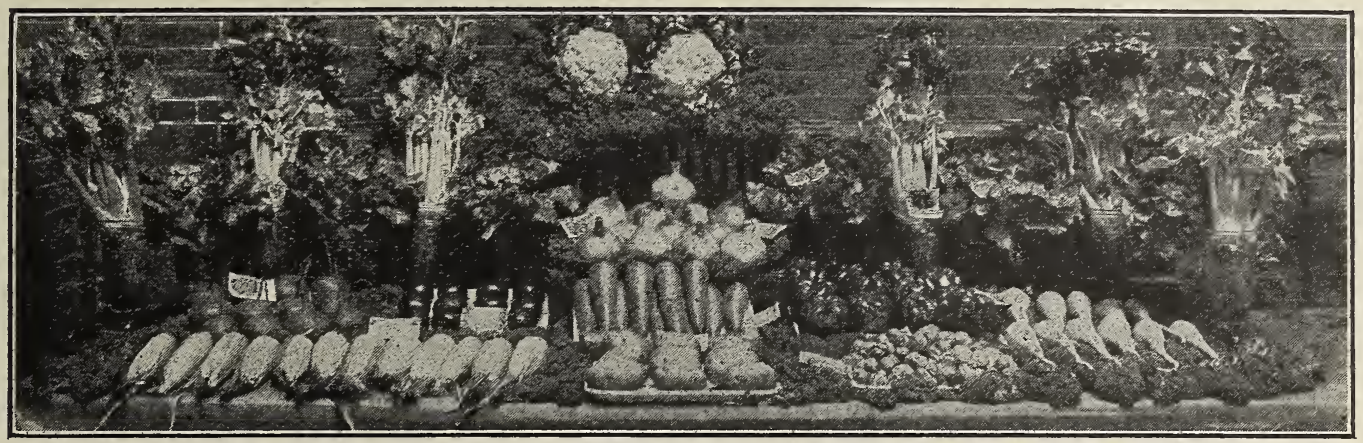

\section{Our Collection of "Favorites" in Vegetables}

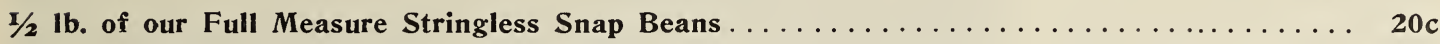

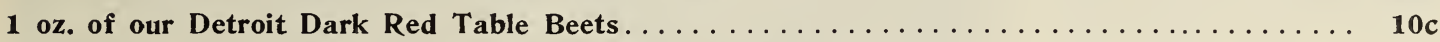

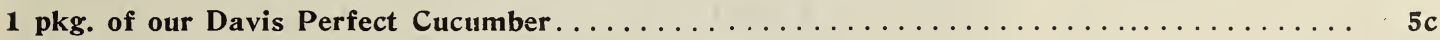

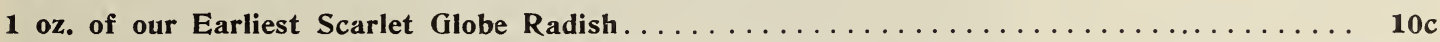

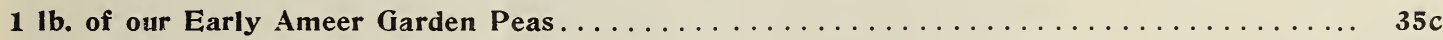

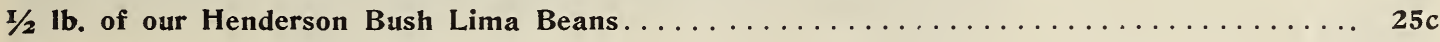

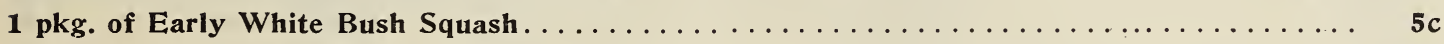

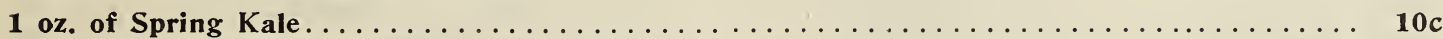

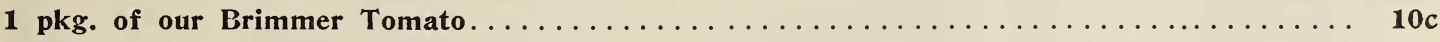

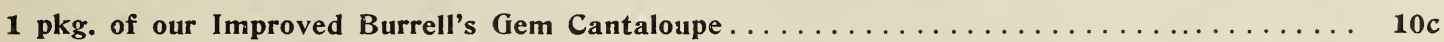

ONE PACKAGE EACH OF THESE “FAVORITES” SENT POSTPAID FOR ........\$1.00

\section{Our "Fragrant Beauty" Collection of Flower Seeds}

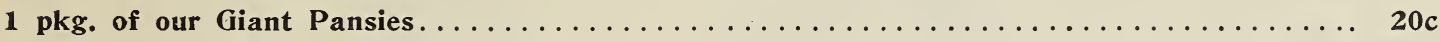

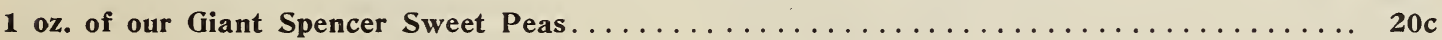

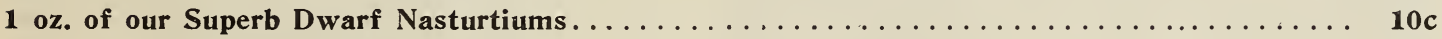

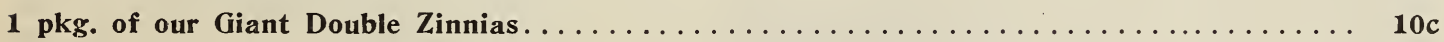

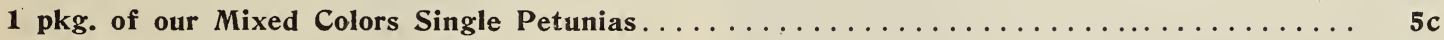

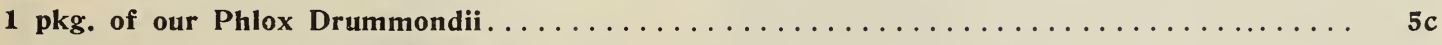

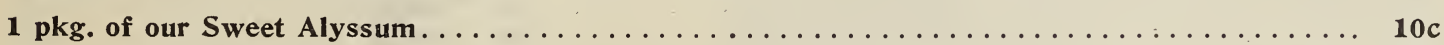

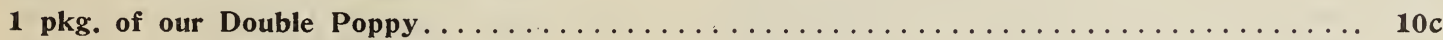

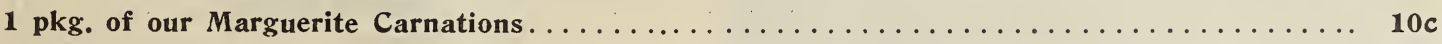




\section{DAY - OLD CHICKS}

At the solicitation of a number of our customers we have made arrangements to endeavor to supply WELL-BRED, DAY-OLD CHICKS to such of our friends who take a pride in their poultry and desire to build up quality and profitproducing flocks.

We will specialize in

\section{Holterman's Aristocrats Barred Rocks \\ Owen's Strain Single= Tancred's Strain White \\ Comb Rhode Island Leghorns \\ Reds}

Prices on Baby Chicks naturally vary with the price of eggs and number of chicks desired, but it will be our aim to furnish chicks at as reasonable a price as WELL-BRED birds can be hatched.

Write us promptly, stating breed, number of birds, and time of delivery desired, and we will take great pleasure in mailing back to you full information.

We will not attempt to meet a competition of mixed or low-grade chicks.

Remember-Your best interests can be served by ordering at least FOUR WEEKS in advance of shipping date.

\section{Cyphers Blue Flame Wickless Oil Burner Hovers}

JUNIOR HOVER........ Capacity, 50 to 100 Chicks. Price, each..........\$10.00

34=INCH HOVER......... Capacity, $\quad 300$ Chicks. Price, each........... 16.00

44=INCH HOVER.......... Capacity, $\quad 500$ Chicks. Price, each........... 18.00

\section{INDEX}

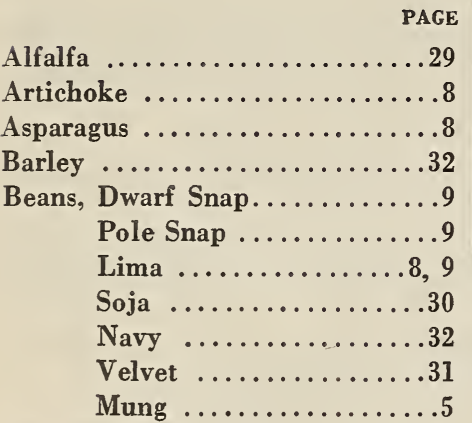

Bee Supplies ..............43

Beets .....................10

Bird Seeds .................. 41

Brussels Sprouts ............

Buckwheat ...................33

Bulbs, Summer Flowering,

2nd cover

Butter Cups ...............41

Cabbage ...................10

Cantaloupe .................16

Carrot ....................11

Cauliflower ...............12

Celery ....................12

Chicks, Day-0ld .............48

Clover Seed ............26, 28

Collards ...................14

Corn, Garden ...........12, 13

Field ................6

Corn Salad ................14

Cotton ................24

Cress .................. 14
PAGE

Cucumber $\ldots \ldots \ldots \ldots \ldots \ldots . \ldots 13$

Dusters ..................24

Egg Plant .................14

Endive .................14

Fertilizers ...............46

Flower Collection ...........47

Flower Seeds............34, 37

Boxes .............41

Garden and Farm Calendar.....4

Garden Cultivators ..........42

Grass, Lawn...........3rd cover

Grass Sreds ...........26, 27

Gourds .................14

Herbs ....................23

Incubators and Brooders....39, 48

Inoculating Cultures ........42

Insecticides $\ldots \ldots \ldots \ldots \ldots \ldots . \ldots 2$

Kaffir Corn ...................32

Kale ...................15

Kohl Rabi ................15

Leek ....................16

Lettuce ..................15

Melon, Water .............17

Millet ....................32

Mustard ..................18

Oats ...................... 30

Onion Seed $\ldots \ldots \ldots \ldots \ldots \ldots \ldots \ldots$

Sets $\ldots \ldots \ldots \ldots \ldots \ldots 18$

Okra ....................... 17

Parsley ................18

Parsnip ...................18

Parcels Post Rates.............
PAGE

Peanuts $\ldots \ldots \ldots \ldots \ldots \ldots \ldots . . . . .33$

Peas, Garden ...............19

Field or Cow..........31

Canada ................31

Pepper ....................19

Plant Bed Canvas............24

Potatoes, Irish ............ 7

Sweet $\ldots \ldots \ldots \ldots \ldots$.

Poultry and Stock Feeds.......41

Poultry Supplies ..........38, 39

Pratt's Poultry Foods and

Remedies...............40

Pumpkin ................20

Radish ...................20

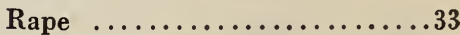

Rhubarb Roots ............21

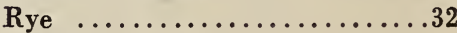

Salsify $\ldots \ldots \ldots \ldots \ldots \ldots \ldots \ldots 21$

Sorghums .................. 32

Spinach .................20

Sprayers and Dusters........44

Spraying Guide ............45

Squash .................21

Teosinte .................

Tobacco .................24

Tomato ................22

Turnip .................23

Vegetable Collection .........47

Vegetable Plants ...........41

Vetches ..................33

Wheat $\ldots \ldots \ldots \ldots \ldots \ldots \ldots \ldots . . . \ldots 32$ 


\section{Lawn Grasses and Requisites}

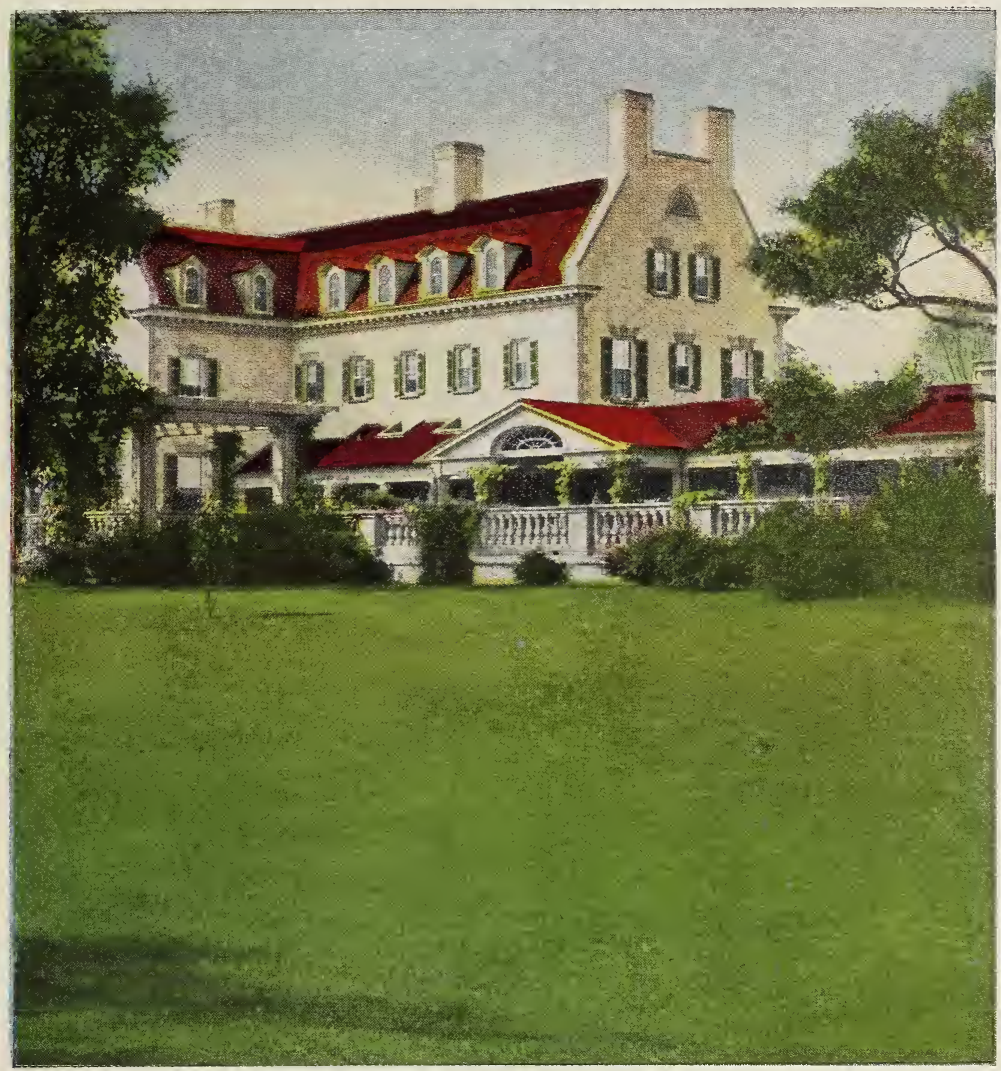

GROSSMIANN'S PERIMANPNT IAWN IIXTURE - This mixture of grasses is recommended for country lawns, large areas, and in instances where the facilities for watering and taking care of the same are not as perfect as the city. The mixture consists of hardy grasses combined so as to make a permanent, smooth, green sod, withstanding heat and droughts of summer, as well as cold of winter. Price, per 1b. 35c; 10 lbs. $\$ 3.00$, postpaid. By freight or express, $30 \mathrm{c}$ per 1b.; 50 1bs. at $28 \mathrm{c}$ per $1 \mathrm{~b}$.

PUIVERIZED SHEEP MANURE - A splendid tor dressing for lawns, adding new life and strength to the grass. Apply broadcast on lawns and rake in with a sharp tooth rake. 50-1b. bag, $\$ 1.50$; 100-1b. bag, $\$ 2.50$.

PURE RAW BONE IMEAI The best and most permanent fertilizer for lawns. Should be used freely in the preparation of new lawns, and should be applied at regular intervals to old and established lawns. 5-1b. pkg. 25c; 50-1b. bag, $\$ 1.50$; 200-1b. bag, $\$ 4.75$.

PURE IAND PIASTER applied as a top dressing. during the summer whendurer the lawns have been cut, retaining and holding the moisture in the land. Price, 200-1b. bag, \$1.75.

\section{Grossmann's Evergreen Iawn Grass.}

\section{HYDRATED IIME FOR IAWNS}

This is recommended to be used when seeding a lawn, also for top dressing lawns already established that are heavily shaded, damp or wet. It corrects acidity and sweetens and improves the soil and promotes the growth. Price, 9-1b. pkg. $25 \mathrm{c} ; 50-1 \mathrm{~b}$. bag, $65 \mathrm{c}$.

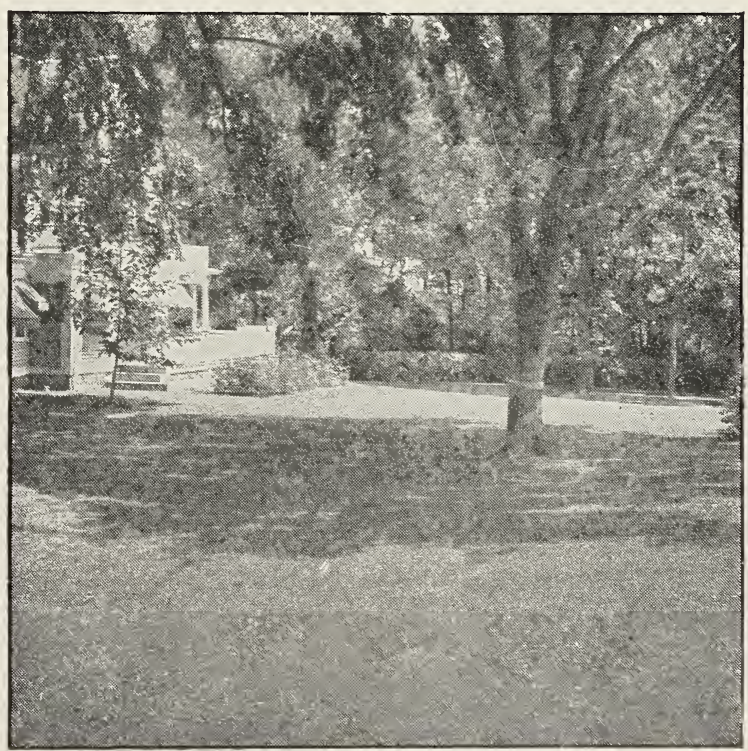

Shady Iawn Grass. 


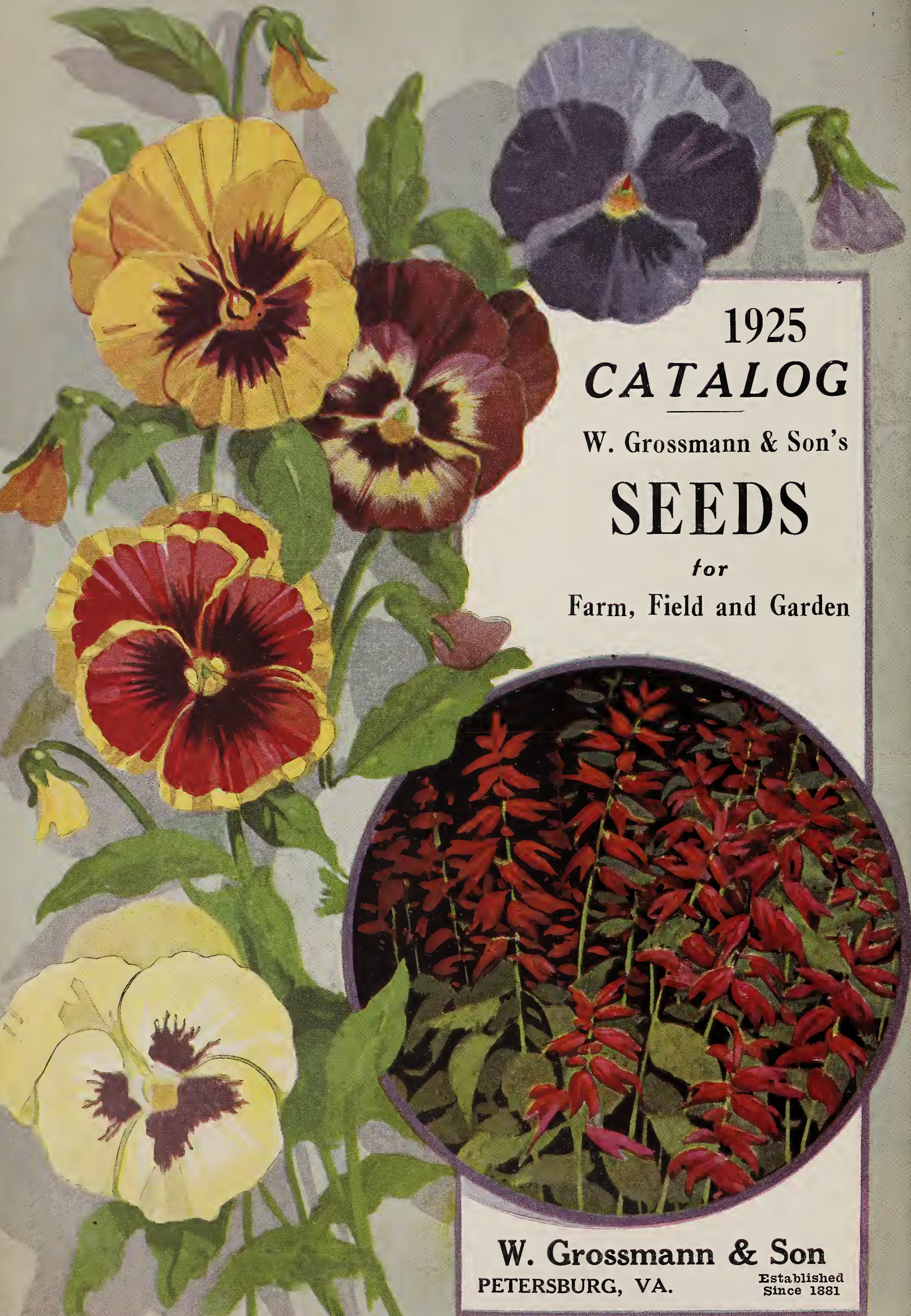

